\author{
UNIVERSIDADE DE SÃO PAULO \\ ESCOLA DE ENGENHARIA DE SÃO CARLOS
}

TAMIRIS DE PAULA ANJOLETTO

Avaliação da temperabilidade do aço SAE 1045 utilizando biofluidos de origem vegetal

São Carlos

2019 



\title{
Avaliação da temperabilidade do aço SAE 1045 utilizando biofluidos de origem vegetal
}

\author{
Versão Corrigida
}

Dissertação apresentada ao programa de Pós-Graduação em Ciência e Engenharia de Materiais da Universidade de São Paulo, para obtenção do título de Mestre em Ciências.

Área de concentração: Desenvolvimento, Caracterização e Aplicação de Materiais.

Orientador: Prof. Dra. Lauralice de Campos Franceschini Canale

\section{São Carlos}




\section{AUTORIZO A REPRODUÇÃO E DIVULGAÇÃO TOTAL OU PARCIAL DESTE TRABALHO, POR QUALQUER MEIO CONVENCIONAL OU ELETRÔNICO, PARA FINS DE ESTUDO E PESQUISA, DESDE QUE CITADA A FONTE.}

Ficha catalográfica elaborada pela Biblioteca Prof. Dr. Sérgio Rodrigues Fontes da EESC/USP com os dados inseridos pelo(a) autor(a).

EESC/USP comos dados inseridos pelo(a) autor(a).
Anjoletto, Tamiris de Paula
Avaliação da temperabilidade do aço SAE 1045
utilizando biofluidos de origem vegetal / Tamiris de
Paula Anjoletto; orientadora Lauralice de Campos
Franceschini Canale. São Carlos, 2019.
Dissertação (Mestrado) - Programa de Pós-Graduação
em Ciência e Engenharia de Materiais e Area de
Concentração em Desenvolvimento, Caracterização e
Aplicação de Materiais -- Escola de Engenharia de são
Carlos da Universidade de São Paulo, 2019.
1. Têmpera. 2. Óleo Vegetal. 3. Curva de
resfriamento. 4. Temperabilidade. 5. Biofluidos. I.
Título.




\section{FOLHA DE JULGAMENTO}

Candidata: Engenheira TAMIRIS DE PAULA ANJOLETTO.

Título da dissertação: "Avaliação da temperabilidade do aço SAE 1045

utilizando biofluidos de origem vegetal".

Data da defesa: 05/07/2019.

Comissão Julgadora:

Resultado:

Profa. Titular Lauralice de Campos Franceschini Canale APROVADA ACPISanc (Orientadora)

(Escola de Engenharia de São Carlos/EESC)

Profa. Dra. Rosamel Melita Muñoz Riofano

(Faculdade de Tecnologia de Franca/FATEC-Franca)

Dr. Marcelo Tadeu Milan

(Materials Institute of Brazil/MIB)

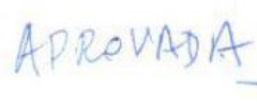

Coordenador do. Programa de Pós-Graduação em Ciências e

Engenharia de Materiais:

Prof. Associado Rafael Salomão

Presidente da Comissão de Pós-Graduação:

Prof. Titular Murilo Araujo Romero 

À minha família, em especial à minha mãe, com gratidão, respeito e amor por seu imenso suporte durante o desenvolvimento deste trabalho. 



\section{AGRADECIMENTOS}

À Professora Dra. Lauralice de Campos Franceschini Canale, que me aceitou como sua orientada e depositou em mim confiança em utilizar seu laboratório.

À Dra. Rosa Lúcia Simencio Otero, pela sua co-orientação, que muito contribuiu para meu crescimento científico e para que este trabalho pudesse ser concluído.

Ao Departamento de Engenharia de Materiais, por colocar à disposição os laboratórios, equipamentos e técnicos capacitados.

Ao Instituto de Materiais Tecnológicos (MIB) por disponibilizar equipamentos de corte, dureza e microscopia óptica para que os ensaios necessários neste trabalho pudessem ser realizados e a equipe que muito colaborou para a interpretação e sugestões de ensaios.

Ao Instituto de Química de São Carlos (IQSC), em especial à Sylvana e o André que realizaram as análises de RMN.

Aos alunos de do grupo de pesquisa da Professora Dra. Lauralice: Bruno Blundi Corona, Luís Henrique Pizetta Zordão e Roberto Ramon Mendonça que se dispuseram a me ajudaram as fazer as têmperas e medidas de viscosidade dos óleos. Enfim, agradeço a todos que de diferentes formas ajudaram na realização desde trabalho, seja direta ou indiretamente.

Muito obrigada a todos! 



\section{RESUMO}

ANJOLETTO, T. P. Avaliação da temperabilidade do aço SAE 1045 utilizando biofluidos de origem vegetal. 82p. Dissertação (Mestrado) -Escola de Engenharia de São Carlos, Universidade de São Paulo, São Carlos, 2019.

Biofluidos como meio de resfriamento para têmpera já são utilizados há centenas de anos. No entanto, aplicações industriais ainda são limitadas e com poucos estudos neste sentido. Apesar de inúmeras vantagens em relação aos de origem mineral (principalmente baixa toxicidade e biodegradabilidade) os óleos vegetais possuem baixa estabilidade térmica, mas que pode ser melhorada por meio de reações químicas ou adição de antioxidantes. Neste trabalho estudou-se o potencial de aplicação como fluido de tempera de cinco fluidos vegetais, óleos de soja, soja epoxidado, girassol, girassol alto oleico e oliva; e que foram comparados entre si e com um fluido mineral comercial utilizado para têmpera. Para isto, estes óleos foram caracterizados em termos de composição de ácidos graxos (AG) e propriedades de resfriamento. Os teores de $A G$, bem como as massas moleculares, foram determinadas utilizando a técnica de Ressonância Magnética Nuclear de Hidrogênio. Os óleos de girassol e soja apresentaram maiores teores de AG poli-insaturados, enquanto que o de oliva apresentou maior teor de ácido oleico. Destaque deve ser dado ao óleo de soja epoxidado que apresentou valores até quatro vezes maior de viscosidade quando comparado aos outros fluidos vegetais. O óleo mineral, como esperado, exibiu viscosidade muito inferior aos outros óleos, o que promove taxas de resfriamento superiores. As curvas de resfriamento, geradas com base na ASTM D6200, destes fluidos exibiram mudança de propriedades após ensaios consecutivos, contudo este comportamento mostrou-se mais sutil para os óleos de soja epoxidado, de girassol alto oleico e oliva. Desta forma, estes (incluindo o óleo mineral) foram selecionados como fluidos de resfriamento na têmpera do aço SAE 1045 sem agitação. Este aço foi selecionado com o intuito de averiguar mudanças mais tênues entre as têmperas, pois se trata de um aço de baixa temperabilidade. A microscopia óptica revelou, assim como as curvas de dureza em $U$, formação de martensita na superfície do aço após as temperas. Como esperado, o desempenho do óleo mineral se mostrou bastante superior aos óleos vegetais, formando durezas da ordem de 62 HRC na superfície. Contudo, no centro as durezas e microestrutura observadas foram 
bastante semelhantes. O coeficiente médio de transferência de calor, calculado a partir das curvas de resfriamento, permitiu boa correlação com as durezas e microestruturas observadas nas amostras. O Poder de Endurecimento se mostrou ineficiente para representar o comportamento dos óleos vegetais, visto que não houve boa correspondência entre os valores e durezas medidas após a têmpera. Destaque deve ser dado para o óleo de soja epoxidado e o de oliva que que exibiram maiores números de coeficiente médio de transferência de calor entre os óleos vegetais analisados e chegaram a formar em torno de $90 \%$ de martensita na superfície. Este estudo permitiu concluir que os óleos de soja epoxidado, girassol alto oleico e óleo de oliva têm potencial aplicação para têmpera, contudo existe a necessidade de maiores investigações de aditivações que contribuam melhor extração de calor de aços de baixa temperabilidade, ou então o direcionamento destes fluidos para tratamento de aços de temperabilidade superior, visto que estes oferecem taxas de resfriamento mais brandas de 300 à $200^{\circ} \mathrm{C}$, minimizando o surgimento de trincas e distorções.

Palavras-chave: Têmpera. Óleo Vegetal. Curva de resfriamento. Temperabilidade. Biofluidos. 


\begin{abstract}
ANJOLETTO, T.P. Evaluation of SAE 1045 quenching using biofluids of vegetable source. 82p. Dissertação (Mestrado) - Escola de Engenharia de São Carlos, Universidade de São Paulo, São Carlos, 2019.
\end{abstract}

Biofluids have been used for hundreds of years as quenchants, however, industrial applications are still limited with few researches in this context. Although many advantages can be pointed, e.g. low toxicity and biodegradability, vegetable oils present low thermal stability, that can be evaded by chemical reactions or using antioxidants. This study investigated five biofluids as potential quenching fluids, soybean, epoxidated soybean, sunflower, high oleic sunflower, and olive oil, as well as a commercial mineral oil (high speed class). In order to compare their performance and for characterization purpose, the fatty acid composition and cooling properties were evaluated. The biofluid fatty acid composition and molar mass were determined using Nuclear Magnetic Resonance of Hydrogen. Highest polyunsaturated fatty acids were found in sunflower and soybean oil; while the olive oil presented highest oleic acid percentage. The epoxidated soybean oil, when compared to other biofluids, exhibited viscosity four times greater than other biofluids. The opposite was observed for the mineral oil, less than half the value exhibited for the other vegetable oils, promoting higher cooling rates. Cooling curves were generated following instructions of ASTM D6200 standard. Property changes were observed for soybean and sunflower oils after consecutive testing, however this behaviour was attenuated for epoxidated soybean, high oleic sunflower and olive oils, due to their low polyunsaturated fatty acid content. Therefore, these oils, including the mineral oil, were selected as quenching fluids for a SAE 1045 steel bar without agitation. This steel is known for its low hardenability, which was important for this study to accurately distinguish the performance offered by each fluid. Optical microscopy revealed, as well as $U$ curves, martensite transformation at surface after quenching. As expected, the mineral oil performance was superior to the biofluid, proving hardness about $62 \mathrm{HRC}$ on surface. However, at the centre this quench provided similar microstructure and hardness. Heat transfer coefficient, calculated from cooling curves, provided good correlation between microstructure and hardness observed. The Hardening Power index proved as an 
inadequate method to evaluate vegetable oils cooling behaviour, since its predictions did not match the hardness measured after quench. Olive and epoxidated soybean oils exhibited greater values of Average Heat Transfer Coefficient among vegetable oils and achieved towards $90 \%$ of martensite on surface. This study proved the potential application of these biofluids for quenching, however further investigation of chemical treatments should be conducted in order to improve their heat extraction. Another possibility is the use of these quenching fluids for steels with better hardenability, considering their milder cooling rates at $300-200^{\circ} \mathrm{C}$, reducing occurrence of distortion or cracks.

Keywords: Quenching. Vegetable Oil. Cooling curve. Hardenability. Biofluids. 


\section{LISTA DE FIGURAS}

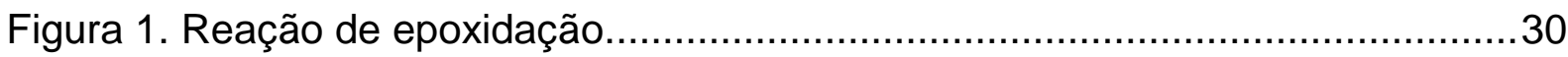

Figura 2. Espectro de $\mathrm{RMN}{ }^{1} \mathrm{H}$ de um óleo vegetal ...............................................

Figura 3. Principais tratamentos térmicos para aços.............................................36

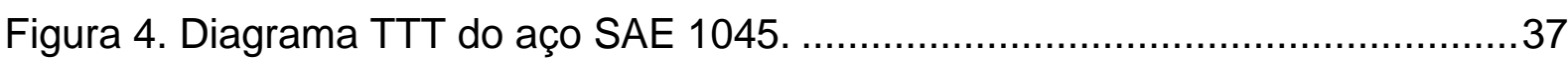

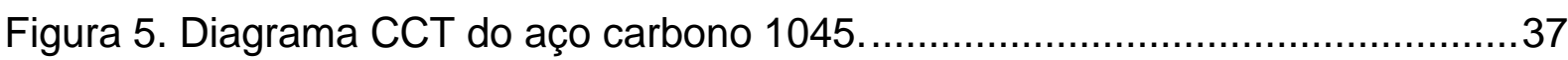

Figura 6. Diagrama de transformação de aço de baixa liga com as curvas de resfriamento para vários fluidos usados em têmpera. 38

Figura 7. Mecanismos de resfriamento durante o processo de têmpera sem agitação.

Figura 8. Curvas de resfriamento de diferentes óleos..........................................

Figura 9.Curvas de resfriamento de óleo em diferentes temperaturas.....................42

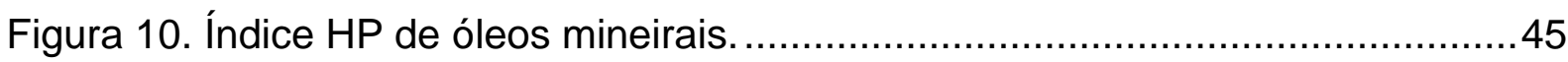

Figura 11. Desenho técnico da montagem da sonda Inconel $600 \ldots \ldots \ldots \ldots \ldots \ldots \ldots \ldots \ldots . . .47$

Figura 12. Parâmetros das curvas de resfriamento.................................................48

Figura 13. Indicações das posições utilizadas para dureza Rockwell na curva em U.

Figura 14. Metodologia empregada neste trabalho para a análise dos materiais. ....51

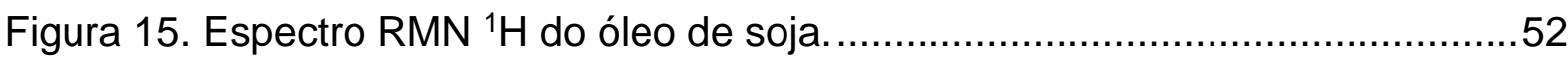

Figura 16. Espectro RMN ${ }^{1} \mathrm{H}$ do óleo de soja epoxidado. .......................................53

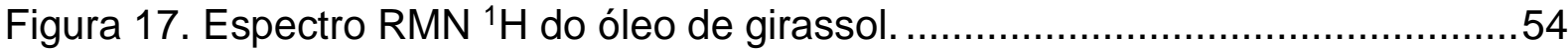

Figura 18. Espectro $\mathrm{RMN}{ }^{1} \mathrm{H}$ do óleo de girassol alto oleico ..................................54

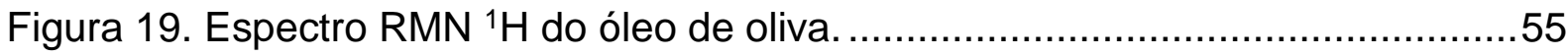

Figura 20. Curvas de Resfriamento do óleo de soja. ............................................58

Figura 21. Curvas de Resfriamento do óleo de girassol.......................................59

Figura 22. Curvas de Resfriamento do óleo de soja epoxidado..............................59

Figura 23. Curvas de Resfriamento do óleo de girassol alto oleico............................60

Figura 24. Curvas de Resfriamento do óleo de oliva..............................................60

Figura 25. Curvas de Resfriamento do óleo mineral. .............................................

Figura 26. Comparação das curvas das taxas de resfriamento. ................................63

Figura 27. Perfil de microdureza Vickers na superfície da barra normalizada...........65 
Figura 28. Curva em U das amostras de aço SAE 1045 após a têmpera em óleo a $60^{\circ} \mathrm{C}$. .66

Figura 29. Dureza superficial das amostras temperadas.

Figura 30. Relação aproximada entre a dureza Rockwell C, teor de carbono e formação de martensita. 68

Figura 31. Correlação entre os métodos para quantificar severidade de têmpera....69 Figura 32. Metalografia do aço SAE 1045 normalizado a $850^{\circ} \mathrm{C}$ por $2 \mathrm{~h}$ e resfriado ao ar superfície e núcleo (ataque em Nital 2\%). Aumento de 100x .70 Figura 33. Metalografia do aço SAE 1045 normalizado a $850^{\circ} \mathrm{C}$ por $2 \mathrm{~h}$ e temperado em óleo de soja epoxidado a $60^{\circ} \mathrm{C}$ superfície e núcleo. Aumentos de 20 e 100x.....71 Figura 34. Metalografia do aço SAE 1045 normalizado a $850^{\circ} \mathrm{C}$ por $2 \mathrm{~h}$ e temperado em óleo de girassol alto oleico a $60^{\circ} \mathrm{C}$ superfície e núcleo. Aumentos de 20 e 100x. .72

Figura 35. Metalografia do aço SAE 1045 normalizado a $850^{\circ} \mathrm{C}$ por $2 \mathrm{~h}$ e temperado em óleo de oliva a $60^{\circ} \mathrm{C}$ superfície e núcleo. Aumentos de 20 e 100x .73 Figura 36. Metalografia do aço SAE 1045 normalizado a $850^{\circ} \mathrm{C}$ por $2 \mathrm{~h}$ e temperado em óleo mineral $\mathrm{HKM} \mathrm{a} 60^{\circ} \mathrm{C}$ superfície e núcleo. Aumentos de 20 e 100x. .74 Figura 37. Metalografia da região branca no centro com dureza Vickers. Aumento de 200x. .75

Figura 38. Influência da razão de aspecto da amostra no fluxo de calor. .75 


\section{LISTA DE TABELAS}

Tabela 1. Principais ácidos graxos e suas estruturas. .....................................27

Tabela 2. Teores de ácidos graxos em diferentes óleos vegetais..........................28

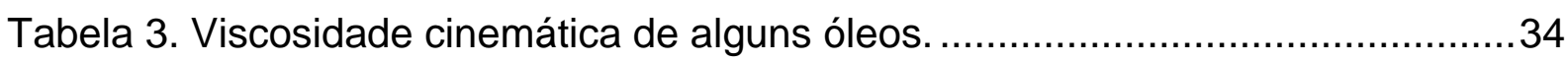

Tabela 4. Siglas e nomes utilizados para os fluidos de resfriamento estudados.......46

Tabela 5. Teores de ácidos graxos em diferentes óleos vegetais...........................56

Tabela 6. Propriedades obtidas pelo espectro de $\mathrm{RMN}{ }^{1} \mathrm{H}$ dos óleos vegetais.........56

Tabela 7. Viscosidade a $60^{\circ} \mathrm{C}$ dos óleos vegetais estudados neste trabalho e

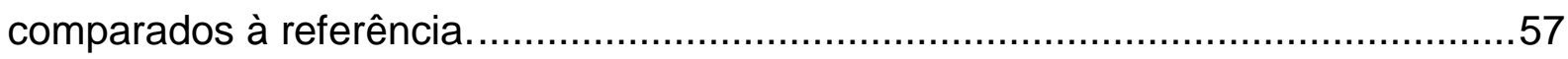

Tabela 8. Resultados extraídos das médias das curvas de resfriamento dos óleos. 62

Tabela 9. Parâmetros para o cálculo do coeficiente de transferência de calor .........63

Tabela 10. Coeficientes médios de transferência de calor. ........................................64

Tabela 11. Poder de endurecimento dos fluidos de têmpera estudados....................64

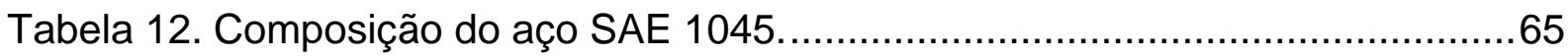

Tabela 13. Formação estimada de martensita na superfície dos fluidos estudados. 68 



\section{LISTA DE SIGLAS}

ABNT - Associação Brasileira de Normas Técnicas

AG - Ácidos Graxos

ASM - American Society of Metals

ASTM - American Society for Testing Materials

CCT - Continuous Cooling Transformation

ESBO - Óleo de Soja Epoxidado

FTIR - Fourier-Transform Infrared Spectroscopy

HOSun - Óleo de Girassol Alto Oleico

HP - Poder de Endurecimento

Proinfa - Programa de Incentivo às Fontes Alternativas de Energia Elétrica

Procel - Programa Nacional de Conservação de Energia Elétrica

PVC - Policloreto de Vinila

RMN'1'H - Ressonância Magnética Nuclear de Hidrogênio

SAE - Society of Automotive Engineers

So - Óleo de Soja

Sun - Óleo de Girassol

TMS - Tetrametilsilano

TTT - Temperature Time Transformation 



\section{LISTA DE SÍMBOLOS}

a - difusividade térmica do metal

A - área de ressonância dos hidrogênios olefínicos

$\mathrm{Bi}_{\mathrm{v}}$ - número de Biot.

B - áreas relacionadas aos hidrogênios dos grupos metilenos

C - áreas relacionadas aos hidrogênios dos grupos metilenos

D - áreas relacionadas aos hidrogênios dos grupos metilenos

E - áreas relacionadas aos hidrogênios dos grupos metilenos

-C - graus Celsius

$\mathbf{C R}_{\text {A-B }}$ - taxa de resfriamento ao atingir a temperatura de Leidenfrost

$\mathbf{C R}_{\max }$ - taxa de resfriamento máxima

$\mathrm{CR}_{700^{\circ} \mathrm{c}}$ - taxa de resfriamento ao atingir $700^{\circ} \mathrm{C}$

$\mathbf{C R}_{300^{\circ} \mathrm{C}}$ - taxa de resfriamento ao atingir $300^{\circ} \mathrm{C}$

$\mathbf{C R}_{200^{\circ} \mathrm{C}}$ - taxa de resfriamento ao atingir $200^{\circ} \mathrm{C}$

$\mathbf{C R}_{500-600^{\circ} \mathrm{C}}$ - Taxa de resfriamento entre 500 e $600^{\circ} \mathrm{C}$

F - área de ressonância dos hidrogênios do grupo metila

F' - área de ressonância dos hidrogênios do grupo metila do ácido linolênico

IV - Índice de lodo

HP - Poder de Endurecimento

K - graus Kelvin

k - fator Kondratjev

Kn - número de Kondratjev

L - ácido linoleico

Ln - ácido linolênico

m - parâmetro que reflete a velocidade de mudança de temperatura

$\mathbf{m}_{\alpha}$ - parâmetro que reflete a velocidade de mudança de temperatura

MM - Massa molar

O - ácido oleico

S - Ácido graxo saturado

S - superfície da sonda

$\mathbf{T}$ - temperatura da sonda

TA-B - temperatura de Leidenfrost 
$t_{A-B}$ - tempo de resfriamento ao atingir a temperatura de Leidenfrost

$T_{\max }$ - temperatura ao atingir taxa de resfriamento máxima

$t_{\max }$ - tempo ao atingir taxa de resfriamento máxima

Tm - temperatura do meio

Tvp - é a temperatura de transição entre os estágios $A$ e $B$

TcP - é a temperatura de transição entre os estágios $B$ e $C$

V - volume da sonda

w - taxa de resfriamento para determinada temperatura

$\alpha$ - coeficiente de transferência de calor

$\lambda$ - condutividade térmica 


\section{SUMÁRIO}

1 INTRODUÇÃO

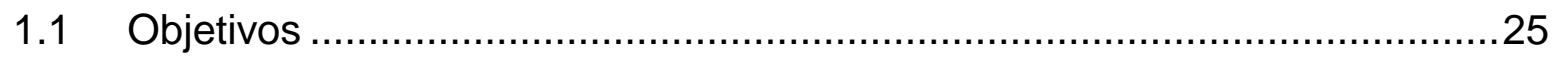

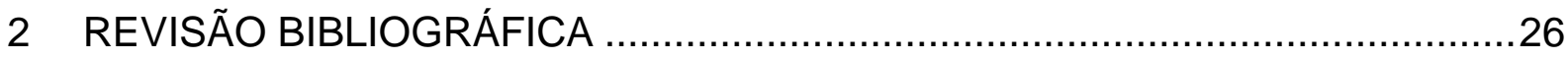

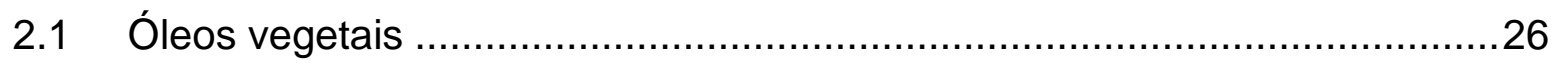

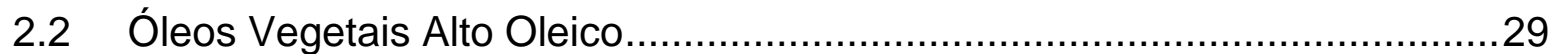

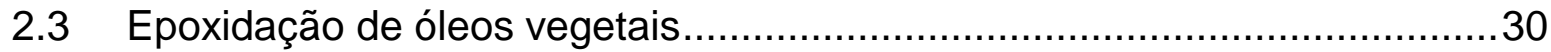

2.4 Ressonância Magnética Nuclear de Hidrogênio $\left(\mathrm{RMN}^{1} \mathrm{H}\right)$.........................31

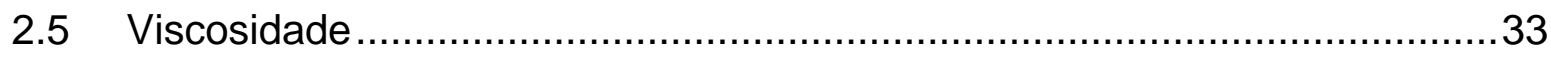

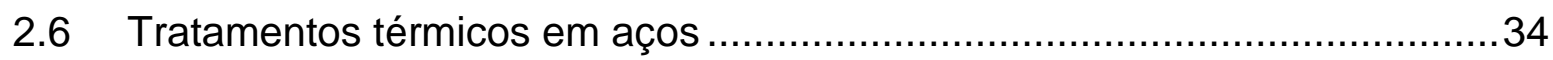

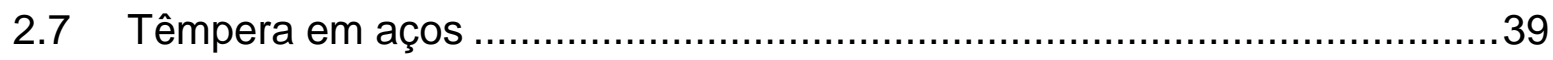

2.8 Coeficiente de transferência de calor ..........................................................

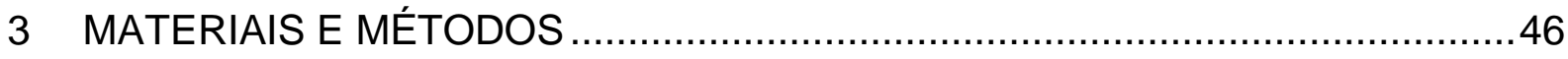

3.1 Caracterização dos óleos vegetais ……………...................................

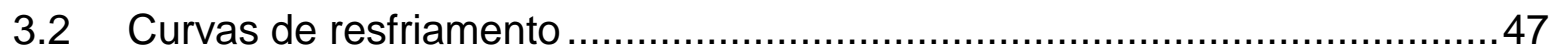

3.3 Análise Metalúrgica do aço SAE 1045 após têmpera …………..................48

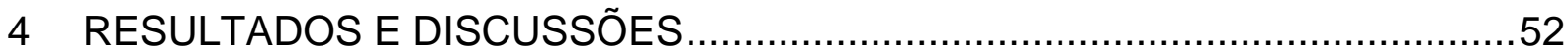

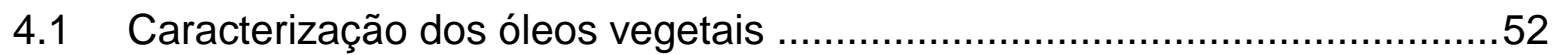

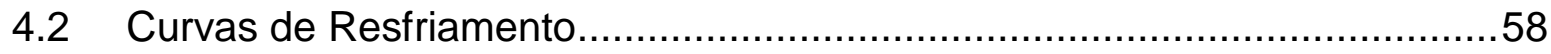

4.3 Análise Metalúrgica do aço SAE 1045 antes e após têmpera......................65

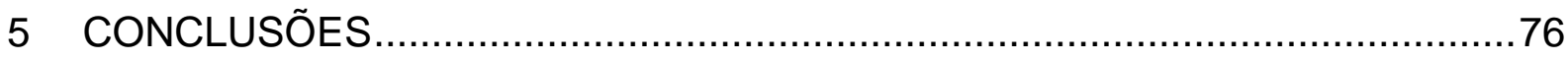

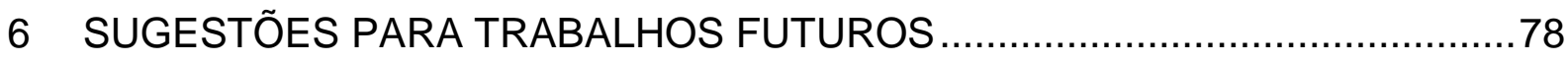

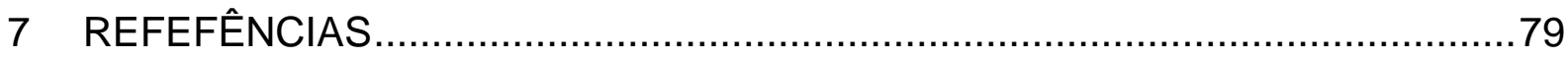





\section{INTRODUÇÃO}

Com o intuito de reduzir o uso de fontes não renováveis de energia, o Brasil tem impulsionado a produção de bioenergia. Neste contexto, o Programa Nacional do Álcool (Proálcool) foi uma das maiores realizações, elaborada com as contribuições importantes e efetivas de universidades e instituições de pesquisa do país (AGÊNCIA FAPESP, 2016). Atualmente, 45,3\% da produção brasileira de energia é proveniente de fontes renováveis, fazendo o país líder neste setor, sendo a média mundial igual a 13 e 6\% para as nações industrializadas e em desenvolvimento, respectivamente (GOVERNO DO BRASIL, 2017).

Além do Proálcool, outros programas foram criados visando aumentar a sustentabilidade do país: Programa de Incentivo às Fontes Alternativas de Energia Elétrica (Proinfa), Programa Nacional de Conservação de Energia Elétrica (Procel), Programa Nacional da Racionalização do Uso de Derivados do Petróleo e do Gás Natural e Programa Nacional de Produção e Uso do Biodiesel (GOVERNO DO BRASIL, 2017). Além de reduzir o consumo de fontes esgotáveis de energia, estes programas movimentam o mercado nacional gerando emprego e renda. Outra consequência positiva é a agregação de valor a commodities, que são de grande importância para o país, que tem sua economia muito dependente do setor primário (GOVERNO DO BRASIL, 2017; DEIVAJOTHIA et al., 2019). Um exemplo disso é o incentivo para a utilização de biodiesel no setor de transporte, tendo o país um papel de destaque no mercado mundial, sendo o terceiro produtor no setor.

Nas últimas décadas, tem aumentado o interesse em substituir os óleos derivados do petróleo por alternativas mais ecológicas, sendo os óleos vegetais e seus derivados excelentes candidatos, principalmente pela biodegradabilidade e por serem provenientes de fontes renováveis. Fluidos de resfriamento formulados a partir de óleos vegetais já são empregados no tratamento de têmpera há centenas de anos e oferecem inúmeras vantagens além da ambiental, quando comparadas aos óleos minerais, entre elas: alto ponto de fulgor e combustão, alta molhabilidade, baixa emissão de voláteis e boa severidade de têmpera (RAMESH; PRABHU, 2014; RA et al., 2015; OTERO et al., 2017; BRITO et al., 2019).

Contudo, um desafio muito grande na aplicação industrial é a baixa estabilidade hidrolítica, térmica e oxidativa destes fluidos, que modifica consideravelmente suas 
propriedades ao longo do uso (RA et al., 2015; OTERO et al., 2017). A presença de insaturações nas cadeias dos ácidos graxos que se rompem facilmente formando radicais livres, torna a estabilidade oxidativa um dos maiores problemas na utilização destes fluidos.

Algumas estratégias podem minimizar este problema dos fluidos vegetais, como a modificação genética e química dos óleos vegetais. Um exemplo é a reação de epoxidação que promove a formação de estruturas mais complexas que provém maior estabilidade termo-oxidativa às cadeias dos ácidos graxos, bem como a melhoria de propriedades de baixa temperatura (MCNUTT; HE, 2016; OTERO et al., 2017).

$\mathrm{Na}$ indústria de fluidos para transformadores, diversas bioformulações já são utilizadas, entre elas a formulação patenteada BIOTEMP®, desenvolvida em 1999, tendo como principal base um óleo alto oleico de origem vegetal, proveniente de sementes transgênicas e reações de hidrogenização parcial que aumentaram sua estabilidade termo-oxidativa. Diversas variedades de sementes modificadas geneticamente são atualmente comercializadas e produzem óleos com diferentes distribuições de teores de ácidos graxos, direcionando seu uso de acordo com suas propriedades (BOCKISCH, 1998; RA et al., 2015). Entretanto, na área de tratamento térmicos a sua utilização é ainda incipiente, com ausência de estudos que analisem sua viabilidade, justificando o interesse no desenvolvimento de fluidos para aplicação em têmpera de metais derivados de fontes renováveis e com estabilidade termooxidativa e hidrólitica melhoradas. Um exemplo é a reação de epoxidação, porém a viscosidade do óleo obtido é bastante elevada quando comparado aos óleos não epoxidados. Isto ocorre, pois em $80-85 \%$ das insaturações é inserido um anel oxirânicos, aumentando a complexidade das cadeias principais, o que dificulta a movimentação entre as mesmas (CAMPANELLA et al., 2008)

Este trabalho busca um melhor entendimento do desempenho de óleos vegetais modificados quimicamente e geneticamente quando comparados aos minerais no tratamento térmico de têmpera de aço SAE 1045. A escolha do aço foi motivada pela sua baixa temperabilidade, permitindo uma fácil distinção entre os resultados proporcionados por diferentes meios de resfriamento. A avaliação dos óleos foi realizada por meio da obtenção de curvas de resfriamento, Ressonância Magnética Nuclear de Hidrogênio, medidas de viscosidade cinemática, Curvas em "U" 
da dureza no aço SAE 1045 e metalografia das seções transversais dos corpos de prova após tratamento de têmpera.

\subsection{Objetivos}

Este trabalho tem como objetivo estudar óleos vegetais com e sem modificação química e genética, visando a aplicação como meios de resfriamento no tratamento térmico de têmpera de aços, onde tradicionalmente são empregadas formulações derivadas do petróleo.

Desta forma, os objetivos específicos deste trabalho foram:

- Investigar as propriedades de resfriamento dos biofluidos e compará-las com fluidos comerciais;

- Avaliar por meio do tratamento térmico do aço SAE 1045 a temperabilidade proporcionada por cada fluido estudado. 


\section{REVISÃO BIBLIOGRÁFICA}

\section{1 Óleos vegetais}

Óleos vegetais, assim como o nome diz, são óleos de origem vegetal, em estado líquido na temperatura ambiente e, normalmente, extraídos de sementes. Diversas aplicações industriais, além do setor alimentício, podem ser citadas, entre elas: farmacêutica, combustíveis, fluido de corte, lubrificante, entre outras aplicações (ADHVARYU et al., 2005; RA et al., 2015). São formados majoritariamente por triacilgliceróis que são moléculas esterificadas de glicerol, com três cadeias de ácidos graxos (AG). Outras substâncias também são encontradas nos óleos vegetais como mono e diglicerídeos, fosfatídeos, ácidos graxos livres, esteróis, pigmentos de carotenoides, tocoferóis e vitaminas, porém o processo de refinamento acaba por promover a remoção total ou parcial de muitas destas substâncias (GUNSTONE, 2005; OTERO et al., 2017).

Os AG distinguem-se no número de insaturações (saturados, monoinsaturados e poli-insaturados) e comprimento (4-24 átomos de carbono), que tem grande influência nas propriedades físico-químicas dos óleos vegetais. Com relação ao comprimento da cadeia carbônica, os AG podem ser classificados como de cadeia: curta (4-8 carbonos), média (8-12 carbonos) e longa (mais de 12 átomos de carbono) (BOCKISCH, 1998; NASCIUTTI et al., 2015; RA et al., 2015).

De forma geral, composições com AG saturados são mais estáveis e possuem cadeias mais longas, aumentando a temperatura de fusão e viscosidade do óleo. A Tabela 1 indica os principais AG, suas fórmulas e estruturas. Monoinsaturados são mais resistentes à rancidez, contudo oxidam mais facilmente quando comparados aos AG saturados. Poli-insaturados tem maior instabilidade temo-oxidativa quanto maior for seu número de insaturações (KODALI, 2002; MCNUTT; HE, 2016). 
Tabela 1. Principais ácidos graxos e suas estruturas.

Ácido Graxo $\quad$ Fórmula

Fonte: adaptado de OTERO et al., 2017.

Os teores de AG presentes nos óleos podem ser definidos por meio de diversos métodos de análise, entre eles: Espectroscopia na região do Infravermelho com Transformada de Fourier (FTIR), Cromatografia Líquida de Alta Performance, Cromatografia a Gás, Espectroscopia de Ressonância Magnética Nuclear (OTERO et al., 2017)

A análise cromatográfica dos óleos de milho, soja, oliva, algodão, amendoim e girassol revelou que dentre eles, o óleo de girassol apresentou o maior teor de AG insaturados $(86,10 \%)$ seguido pelo óleo de soja $(84,15 \%)$, enquanto que o óleo de algodão apresentou o maior teor de AG saturados (24,23\%). Nesta análise também 
foi reportado que os AG mais abundantes insaturados foram o oleico (18:1) e linoleico (18:2); e palmítico (16:0), entre os saturados (FONSECA; GUTIERREZ, 1974). A Tabela 2 indica as composições graxas de diversos óleos vegetais.

Tabela 2. Teores de ácidos graxos em diferentes óleos vegetais.

\begin{tabular}{ccccc}
\hline \multirow{2}{*}{ Óleos vegetais } & \multicolumn{4}{c}{ Teores de ácidos graxos } \\
\cline { 2 - 5 } & Saturados & Oleico & Linoleico & Linolênico \\
\hline Oliva & 14,5 & 75,5 & 7,5 & 1 \\
Girassol alto oleico & 9,0 & 75,0 & 16,0 & 0 \\
Amendoim & 17,5 & 55,0 & 25,0 & 0 \\
Gergelim & 13,5 & 42,0 & 44,5 & 0 \\
Milho & 13,5 & 32,5 & 52,0 & 1 \\
Girassol & 12,0 & 23,0 & 63,0 & $<0,5$ \\
Semente de abóbora & 21,0 & 24,0 & 54,0 & 0,5 \\
Cártamo & 9,0 & 12,0 & 78,0 & 0,5 \\
Soja & 15,5 & 21,0 & 53,0 & 8,0 \\
Nozes & 11,0 & 16,0 & 59,0 & 12,0 \\
Linhaça & 10,0 & 18,0 & 14,0 & 58,0 \\
\hline
\end{tabular}

Fonte: adaptado de GUILLÉN, 2003.

Propriedades como acidez, densidade, viscosidade, cor, índice refrativo, umidade, volatilidade, constante dielétrica, índice de iodo, teores de peróxidos, éster e carbonilas, são indicadores da qualidade e estabilidade de um óleo vegetal, sendo que muitas delas sofrem significativa alteração em função da temperatura e diferentes composições de AG.

Como já mencionado, os óleos vegetais em sua forma original contêm diversas substâncias além de ácidos graxos e comumente são empregados tratamentos (processos industriais complementares) a estes óleos para suas propriedades sejam ideais às suas aplicações, entre eles:

- Refinamento: remoção por meio de processos químicos ou físicos (e.g. vaporização) de ácidos graxos livres, proteínas, fosfolipídios, gomas e outros compostos insolúveis(CREVEL et al., 2000; OTERO, 2014);

- Clareamento: realizado por meio de absorventes como argila ou bentonita tratada com ácidos inorgânicos (ácido clorídrico ou sulfúrico), este processo é 
capaz de alterar a coloração e odor dos óleos(KHAN, 2015; OTERO et al., 2017);

- Desodorização: processo em que o óleo é aquecido na ausência de ar e tem seus vapores removidos (OTERO et al., 2017);

- Winterização: remoção de composto de alto ponto de fusão por meio de filtração ou decantação à baixas temperaturas;

- Hidrogenação parcial: como nome sugere, adição de hidrogênios às cadeias insaturadas. Este processo aumenta a estabilidade do óleo, a resistência à oxidação e é muito empregado nas indústrias alimentícia, farmacêutica, lubrificantes, combustíveis etc. (BOLDRINI, 2018);

- Modificação genética: entre diversas modificações é possível enriquecer um óleo vegetal de determinado ácido graxo. Na literatura foi reportado o óleo extraído de sementes de soja transgênica (que tradicionalmente tem 25\% de ácido oleico) com até $80 \%$ de ácido oleico (MCNUTT; HE, 2016).

\section{2 Óleos Vegetais Alto Oleico}

Como já mencionado, o ácido oleico é monoinsaturado, e portanto, mais estável que AG poli-insaturados, o que lhe garante maior estabilidade em termos oxidativos (MCNUTT; HE, 2016; OTERO et al., 2017). Além desta vantagem, este AG possui excelente propriedade a baixa temperatura garantindo um potencial de aplicação na indústria de lubrificantes (MCNUTT; HE, 2016).

Na indústria alimentícia, a hidrogenação parcial de AG poli-insaturados como o linoleico e linolênico é amplamente utilizada para melhorar a estabilidade oxidativa de óleos vegetais. Contudo, este processo pode criar compostos indesejáveis, como os compostos trans (HUTH et al., 2015). Uma alternativa mais viável, é a modificação genética das sementes, que como citado anteriormente, pode produzir óleos com teores de oleico muito elevados, o que é um atrativo tanto para a indústria alimentícia, como para os meios de resfriamento utilizados em têmpera. Vale ressaltar que a adição de antioxidantes, pode potencializar a resistência destes óleos, por cessar o efeito dos radicais livres formados pela degradação (seja por luz, contato com metal ou permanência a altas temperaturas). O custo destes óleos em relação aos comuns é o dobro, porém conforme a demanda aumentar estes valores podem se igualar (SMITH et al., 2007; OTERO, 2014; MCNUTT; HE, 2016). 


\subsection{Epoxidação de óleos vegetais}

A reação de epoxidação é utilizada principalmente para melhorar a estabilidade de óleos vegetais (sem comprometer sua biodegradabilidade), além de melhor acidez e adsorção a superfícies metálicas (MCNUTT; HE, 2016). É amplamente empregada na modificação química do óleo de soja, mas também de canola e girassol.

Os óleo vegetais epoxidados são reportados na literatura como tendo diversas aplicações: lubrificantes, espumas de poliuretana, plastificantes e estabilizantes de policloreto de vinila (PVC), onde tradicionalmente eram empregados derivados do petróleo (Jl et al., 2019). A reação basicamente converte as insaturações presentes nos ácidos graxos em grupos oxirânicos (RANGARAJAN et al., 1995; SAMARTH; MAHANWAR, 2015; Jl et al., 2019; KHUNDAMRI et al., 2019).

A reação mais comum empregada é a Prileszhaev que insere os grupos epóxidos por meio do uso de perácidos (os mais frequentes em processos industrias são peróxido-acético ou peróxido fórmico), formados pela reação entre um ácido e peróxido de hidrogênio. Contudo após a reação com a insaturação o perácido volta a ser ácido e reage com uma nova molécula de peróxido. Assim, ao final da epoxidação do óleo vegetal é necessário neutralização desses ácidos (GAMAGE et al., 2009). A Figura 1 apresenta a reação descrita de epoxidação. Esta reação gera um aumento na viscosidade do óleo, o que não é desejado para sua aplicação como fluido de têmpera, pois tende a reduzir as taxas de resfriamento durante a têmpera. Esta viscosidade pode ser ajustada com reações de esterificação ou acetilação, que melhoram também a lubricidade, propriedades de baixa temperatura e redução de coeficiente de friç̧ão (RANGARAJAN et al., 1995; ADHVARYU; ERHAN, 2002; ADOLFSSON, 2004; CAMPANELLA et al., 2008; MCNUTT; HE, 2016).

Figura 1. Reação de epoxidação.

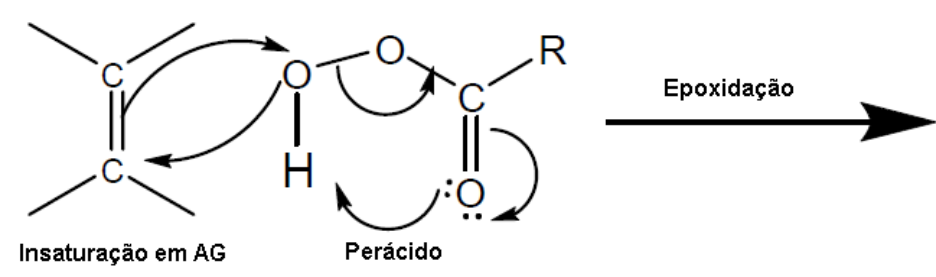

Fonte: adaptado de GAMAGE et al., 2009.
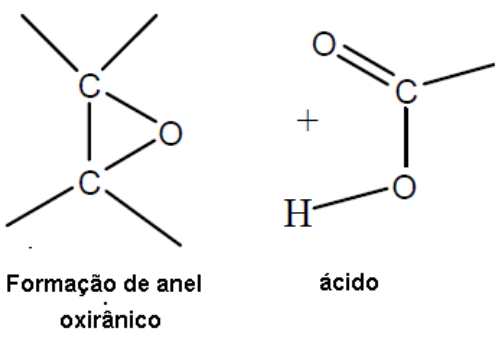


\subsection{Ressonância Magnética Nuclear de Hidrogênio (RMN ${ }^{1} \mathrm{H}$ )}

A Espectroscopia de Ressonância Magnética Nuclear de Hidrogênio fornece dados sobre a quantidade de ligações de hidrogênio na amostra. Desta forma, a técnica tem sido frequentemente empregada na identificação da composição graxa de óleos vegetais, classe de lipídeos, estrutura molecular, conformação molecular, posição, número de insaturações, geometria das duplas ligações, acidez e massa molar média (OTERO, 2014). Ao contrário da Cromatografia Gasosa, mais comumente empregada na determinação dos perfis de $A G$ em óleos vegetais, as amostras não necessitam de transformações químicas previamente a realização da análise e tem seu resultado resumido a um espectro, Figura 2 (HOPKINS; BERNSTEIN, 1959; GUILLÉN; RUIZ, 2003; DAIS et al., 2007).

Figura 2. Espectro de $\mathrm{RMN}{ }^{1} \mathrm{H}$ de um óleo vegetal

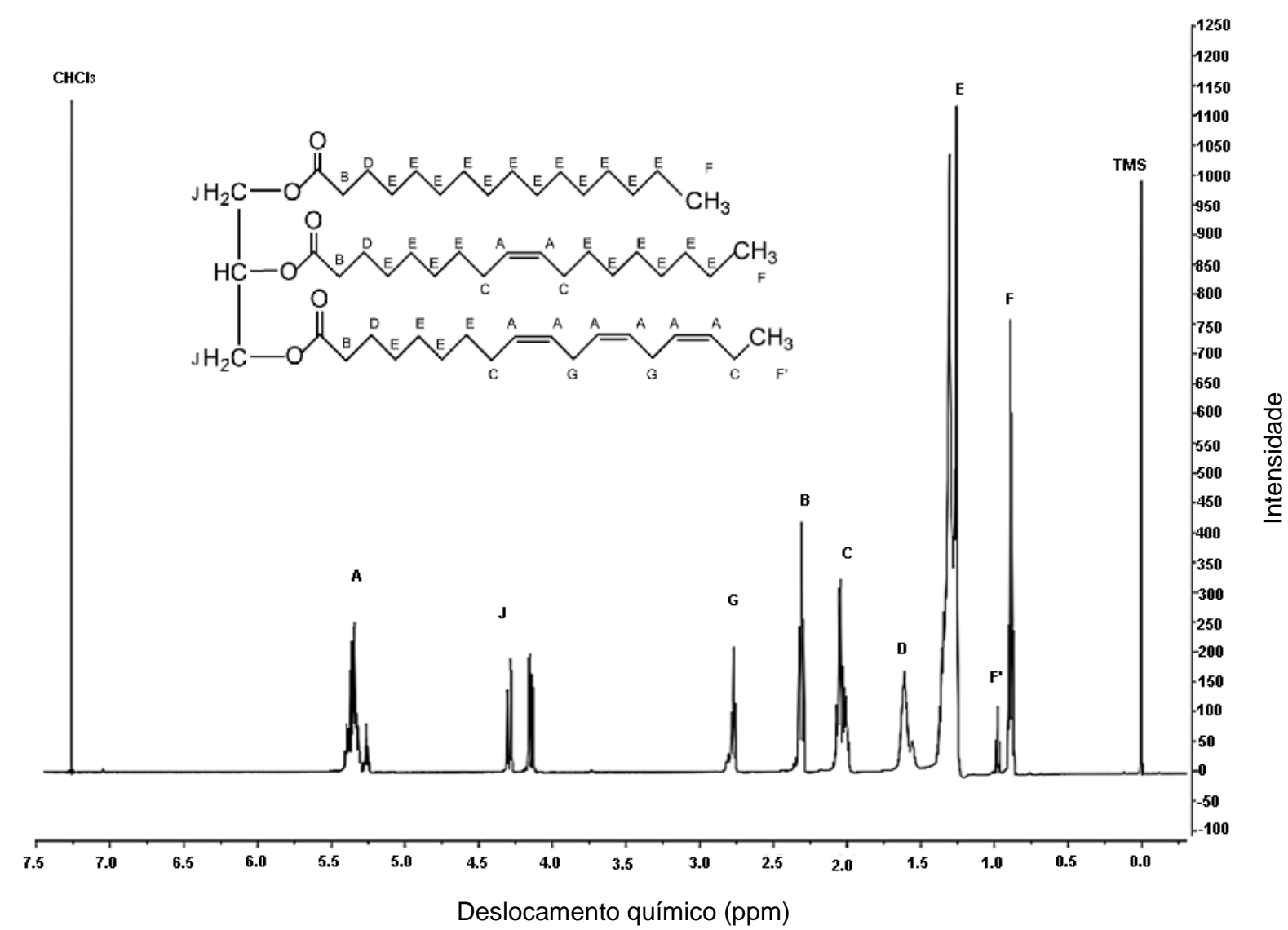

Fonte: OTERO, 2014.

Guillén e Ruiz (2003) determinaram, além do índice de iodo e massa molar (IV e $M M$, respectivamente), a proporção de $A G$ saturados $(S)$, oleico $(O)$, linoleico (L) e 
linolênico (Ln) em sessenta e seis amostras de óleos, empregando as Equações 1 a 6. Em geral, os resultados obtidos mostraram pouca variação quando comparados aos valores obtidos por GC e também descritos na literatura.

É válido ressaltar que o índice de iodo é um indicativo muito importante na análise de óleos, principalmente o óleo de oliva e o de coco, para determinar se existe adulteração dos mesmos. Este índice se relaciona com o número de insaturações presentes no óleo analisado e pode ser obtido por meio da técnica de $\mathrm{RMN}{ }^{1} \mathrm{H}$, assim como a massa molar média. Expresso em centigramas de iodo absorvido por grama de óleo, ou seja, a porcentagem de iodo absorvido pelo óleo. As duplas ligações presentes nos $A G$ reagem com o iodo (processo conhecido como halogenação), assim quanto maior o índice de iodo maior a quantidade de insaturações. Portanto se um óleo de oliva apresenta elevados teores de poli-insaturados, provavelmente foi feita adulteração com outros óleos mais baratos como o de soja ou girassol (KODALI, 2002; LEONARDI et al., 2018).

No espectro de $\mathrm{RMN}{ }^{1} \mathrm{H}$, cada posição do hidrogênio no ácido graxo se manifesta com um sinal diferente e as intensidades se relacionam com a quantidade presente no material. Assim como outras técnicas é utilizado um sinal característico como fator de normalização, que no caso do RMN ${ }^{1} \mathrm{H}$ em óleos vegetais é o $\mathbf{J}$ dividido por 4 (por se tratar de 4 hidrogênios). Esta técnica permite a diferenciação entre os AG com 0,1, 2 ou 3 duplas ligações devido à sobreposição de sinais, portanto as condições de ensaio (e.g. tempo de relaxação, pulso, tempo de aquisição e largura espectral) são de extrema importância para obtenção de resolução adequada dos sinais, evitando quantificações equivocadas (MANNINA; SEGRE, 2002; GUILLÉN; RUIZ, 2003; MAMBRINI et al., 2012; OTERO, 2014).

$$
\begin{gathered}
M M=120+7,013 * 100+6,006 x A \\
I V=\frac{12691 x A}{M M}
\end{gathered}
$$

Onde:

A = a área de ressonância dos hidrogênios olefínicos $(26,016 \mathrm{~g})$. 
O teor de ácidos graxos também é possível ser determinado via $R M N{ }^{1} \mathrm{H}$, a seguir as equações indicam como o cálculo é realizado para os $A G$ saturados $(S)$, oleico $(O)$, linoleico $(L)$ e linolênico $(L n)$.

$$
\begin{gathered}
S(\%)=100\left(1-\frac{C}{2 B}\right) \\
O(\%)=100\left(\frac{C}{2 B}-\frac{G}{B}+\frac{F^{\prime}}{F+F^{\prime}}\right) \\
L(\%)=100\left(\frac{G}{B}-2 \frac{F^{\prime}}{F+F^{\prime}}\right) \\
\operatorname{Ln}(\%)=100\left(\frac{F^{\prime}}{F+F^{\prime}}\right)
\end{gathered}
$$

Onde:

$\mathbf{F}=$ a área de ressonância dos hidrogênios do grupo metila $(\mathrm{CH} 3: 15,034 \mathrm{~g})$ presentes nos ácidos graxos saturados e nos ácidos oleico e linoleico;

F' = a área de ressonância dos hidrogênios do grupo metila do ácido linolênico;

B, C, D, E e G = áreas relacionadas aos hidrogênios dos grupos metilenos (14,026 g).

\subsection{Viscosidade}

A viscosidade é a resistência de um fluido ao cisalhamento é resultado da movimentação entre as moléculas de um fluido. Esta propriedade física é de extrema importância para certas aplicações como lubrificantes, pois permite a extração eficiente de calor no movimento entre peças, reduzindo o desgaste e promovendo durabilidade dos componentes envolvidos.

A temperatura exerce uma forte influência na viscosidade de um fluido. No caso da têmpera, esta relação é fundamental na extração de calor do metal. Ao resfriar a superfície metálica, o fluido é aquecido e tem sua viscosidade reduzida, o que aumenta a eficiência da troca de calor entre o metal e fluido (RAMESH; PRABHU, 2014). 
A viscosidade de óleos minerais é normalmente mais baixa que de óleos vegetais, oferecendo superior molhabilidade em peças metálicas. A Tabela 3 indica as viscosidades de alguns óleos vegetais quando comparados aos minerais. Nota-se sutis diferenças entre os óleos vegetais (OTERO et al., 2017).

Nos óleos vegetais, a medida de viscosidade é também uma forma de avaliar a degradação de um óleo, existe uma tendência de aumento na viscosidade causado pela formação de radicais livres na degradação termo oxidativa de um óleo. Formando cadeias mais complexas e de massa molar maior que dificultam a movimentação entre as moléculas. Óleos com maiores teores de insaturações estão mais propensos a este efeito (ADHVARYU et al., 2000; SAMARTH; MAHANWAR, 2015; OTERO et al., 2017).

Tabela 3. Viscosidade cinemática de alguns óleos.

\begin{tabular}{lcc}
\hline \multicolumn{1}{c}{ Óleos } & $\begin{array}{c}\text { Viscosidade } \\
\text { Cinemática (cSt) } \\
\text { a 40 } \mathbf{C}\end{array}$ & $\begin{array}{c}\text { Viscosidade } \\
\text { Cinemática (cSt) } \\
\text { a 100 } \mathbf{C}\end{array}$ \\
\hline Canola & 34,9 & 7,9 \\
Milho & 33,5 & 7,7 \\
Semente de & 33,9 & 7,8 \\
algodão & 31,5 & 7,5 \\
Soja & 33,2 & 7,8 \\
Girassol & & \\
Óleo Mineral & 40,0 & 6,7 \\
Temp 153 B & & \\
(acelerado) & & \\
\hline
\end{tabular}

Fonte: Adaptado de OTERO et al., 2017.

\subsection{Tratamentos térmicos em aços}

Tratamentos térmicos são procedimentos de aquecimento e resfriamento em que um metal ou liga metálica no estado sólido é submetido de modo a adquirir as propriedades desejadas.

Entre os principais tratamentos térmicos tem-se:

- Normalização: este tratamento tem como objetivo a homogeneização ou refino de grão, uniformizando a composição em toda extensão da peça. Este processo acontece com a austenitização do aço e em seguida o resfriamento ao ar. O processo é feito com $55^{\circ} \mathrm{C}$ acima do limite superior da zona crítica do diagrama Ferro-Cementita, que para aços de baixo carbono é por volta de $870^{\circ} \mathrm{C}$. 
- Recozimento: consiste do aquecimento do material com o objetivo de modificar propriedades e microestrutura, de forma a facilitar processamento do material (usinagem ou trabalho a frio) ou ainda alívio de tensões residuais.

- Endurecimento superficial: com o objetivo de aumentar a resistência ao desgaste da superfície do aço e ao mesmo tempo manter a tenacidade no núcleo, este é um conjunto de tratamentos em que a peça é submetida. Um aço de baixo carbono é submetido a cementação (por meio de atmosfera de monóxido de carbono ou carbono proveniente de carvão) superficial, facilitando a formação de martensita na superfície. Outros tratamentos como carbonitretação e nitretação também proporcionam aumento da dureza superficial.

- Têmpera: tratamento em que o aço austenitizado é resfriado em um meio líquido ou gasoso de modo a buscar microestrutura martensítica. A formação desta fase irá depender das condições e meios de resfriamento (óleo, água, salmoura ou solução polimérica), assim como a temperabilidade do aço e geometria da peça.

- Revenimento: tipicamente, o objetivo deste tratamento é tenacificar ou aumentar a ductilidade de uma peça após tratamento de têmpera. Neste tratamento térmico acontece a eliminação de discordâncias, crescimento e esferoidização de partículas de cementita. É realizado com o aço aquecido abaixo do limite inferior de transformação (entre 205 e $595^{\circ} \mathrm{C}$ ) balanceando dureza e tenacidade (FLINT et al., 1995).

A Figura 3 apresenta um fluxograma dos principais tratamentos térmicos para aços. 
Figura 3. Principais tratamentos térmicos para aços.

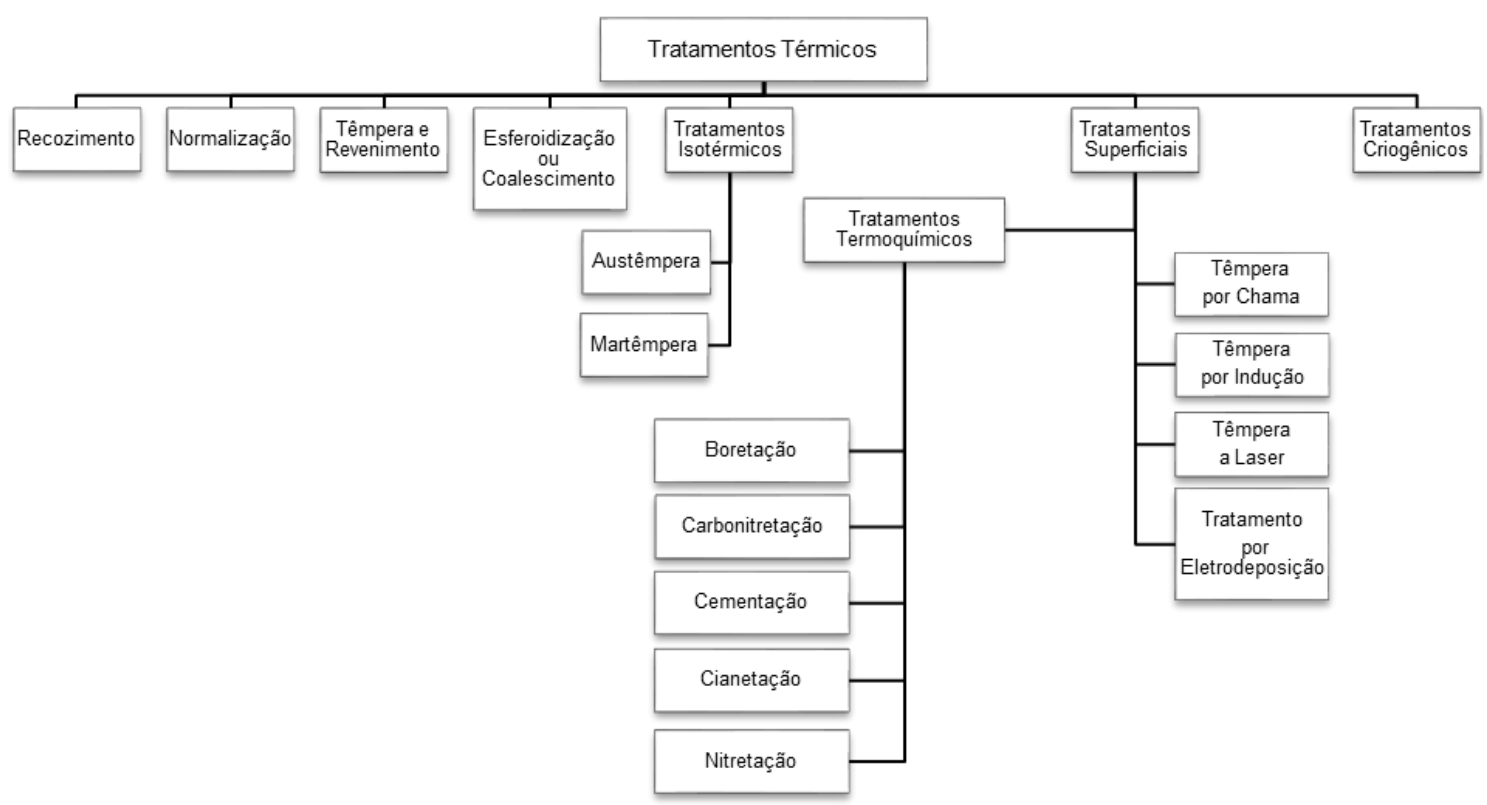

Fonte: Adaptado de KRAUSS, 1989.

Por se tratarem de transformações bastante dependentes do tempo, diagramas TTT (Tempo Temperatura Transformação) auxiliam na avaliação de tratamentos isotérmicos. Um exemplo deste diagrama pode ser visto na Figura 4 (TOTTEN et al., 2002; CHIAVERINI, 2008).

Os diagramas CCT (Transformação por Resfriamento Contínuo), Figura 5, são os mais indicados para a maioria dos tratamentos térmicos convencionais. Para tratamentos de resfriamento contínuo, estas curvas indicam as taxas resfriamento críticas para obtenção de microconstituintes, para o caso da têmpera, por exemplo, o 'nariz’ desta curva indica a taxa de resfriamento necessária para evitar a formação de perlita. 
Figura 4. Diagrama TTT do aço SAE 1045.

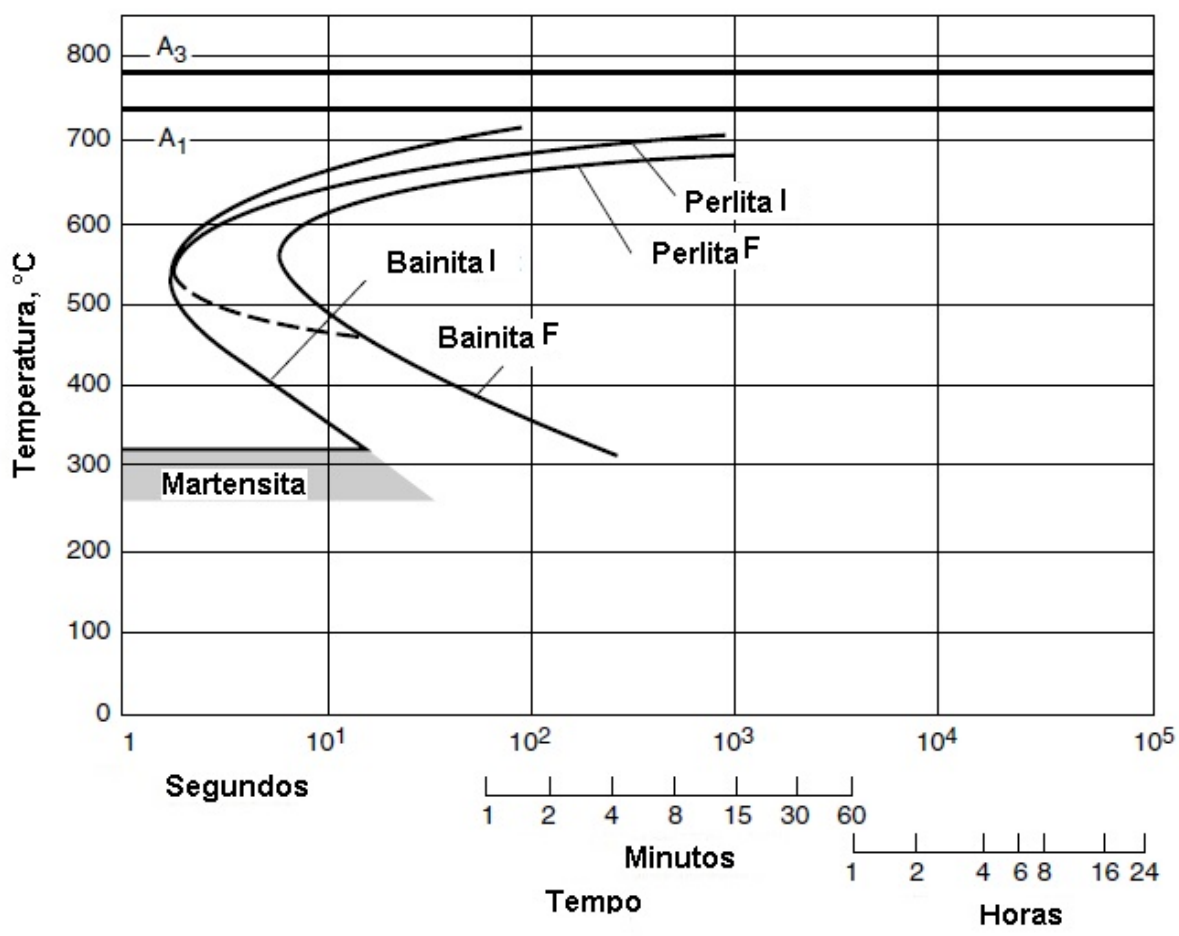

Fonte: Adaptado de (TOTTEN et al., 2002).

Figura 5. Diagrama CCT do aço carbono 1045.

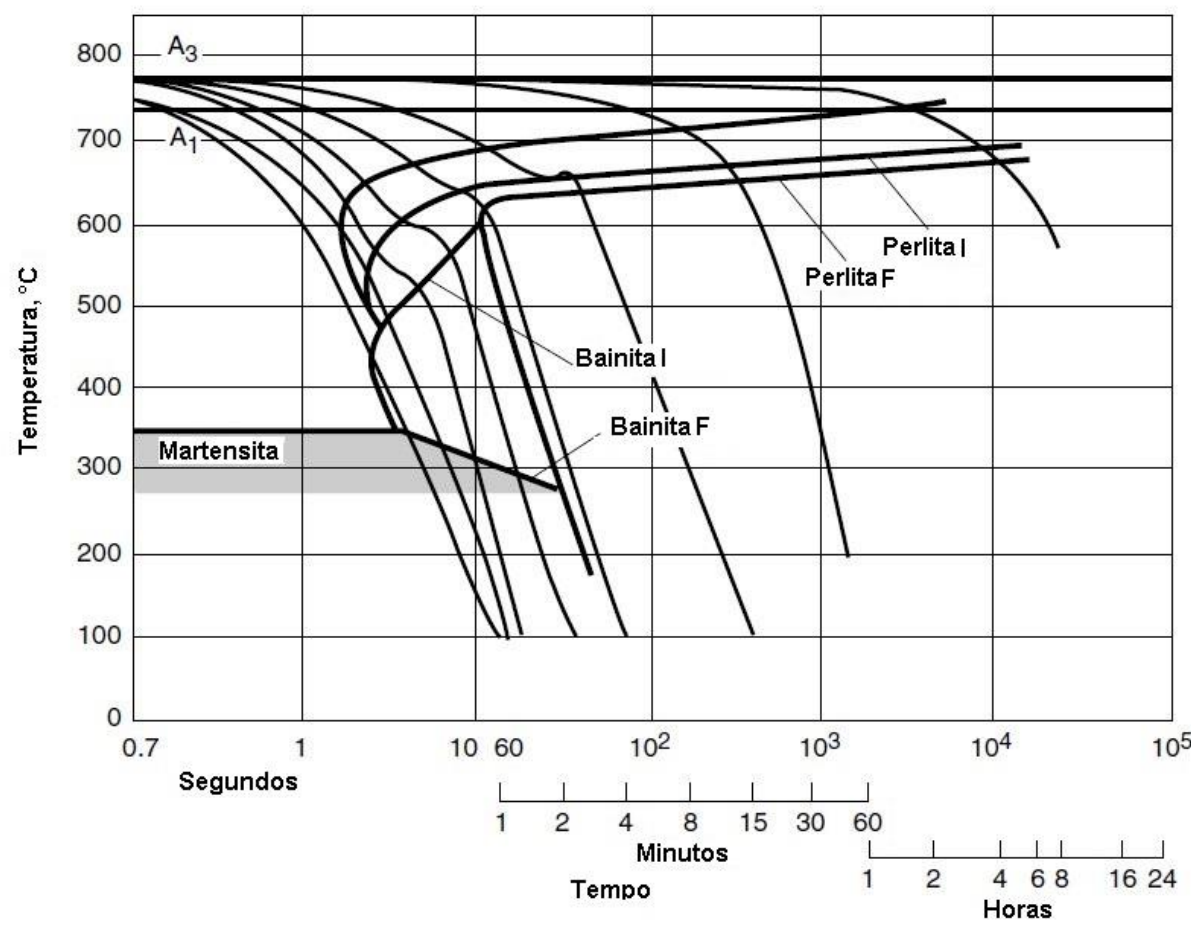

Fonte: Adaptado de (TOTTEN et al., 2002). 
A Figura 6 indica diversas curvas de resfriamento obtidas em diversos meios de resfriamento e a formação de microconstituintes em cada uma delas. Nota-se que para meios de resfriamento mais severos como a água fria $(A)$ e óleo mineral acelerado (B), a formação de martensita é completa. Já para meios menos severos (C) existe formação de perlita ou bainita junto à martensita. Contudo, em meios que são incapazes de remover calor do metal suficientemente rápido, como o ar (E), existe a completa transformação em perlita.

É válido ressaltar que para cada aço existe um diagrama de transformação. Aços com elevado teor de carbono e elementos de liga tem o "nariz" da curva mais para a direita, facilitando a formação de martensita. Esta propriedade é definida como temperabilidade. Outros fatores como temperatura de austenitização e tamanho de grão também afetam a facilidade do aço em formar martensita (TOTTEN et al., 1993).

Figura 6. Diagrama de transformação de aço de baixa liga com as curvas de resfriamento para vários fluidos usados em têmpera.

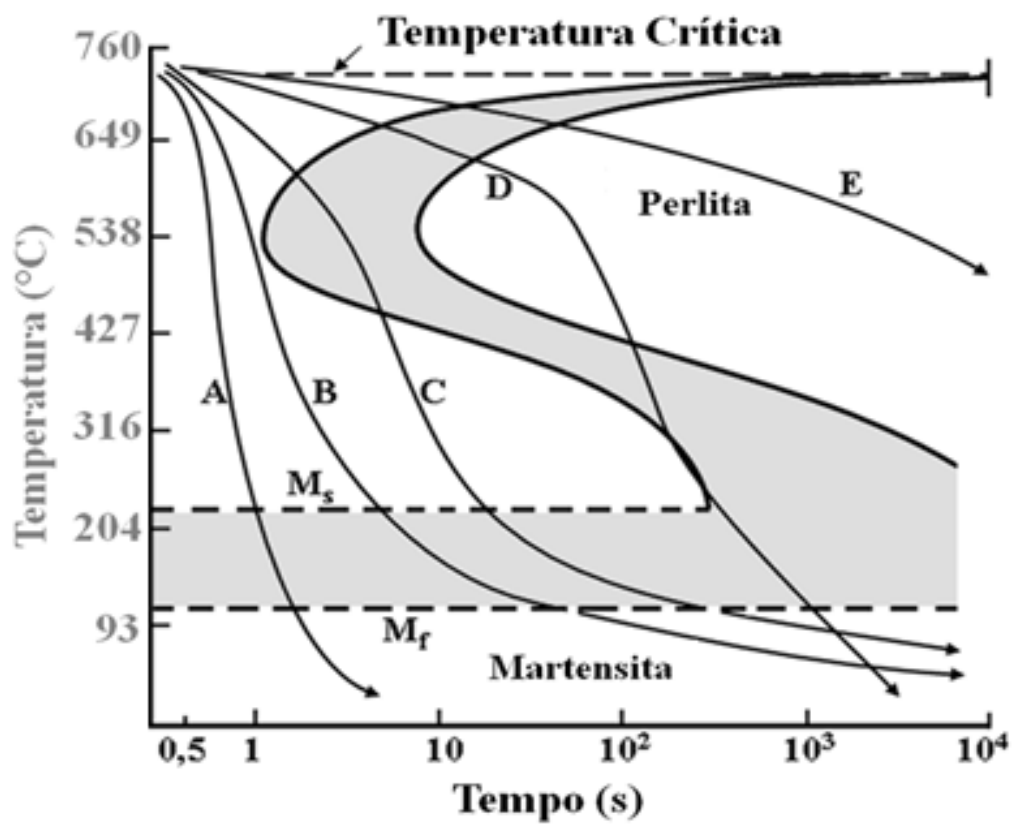

$$
\begin{aligned}
& A=\text { água fria } \\
& B=\text { óleo derivado de petróleo (acelerado) } \\
& C=\text { óleo derivado de petróleo (convencional) } \\
& D=\text { água a } 82^{\circ} \mathrm{C} \\
& E=\text { ar }
\end{aligned}
$$

Fonte: Adaptado de TOTTEN et al., 1993. 


\subsection{Têmpera em aços}

Conforme já mencionado, este é um tratamento que visa o aumento da dureza por meio da austenitização do aço e posterior transformação em martensita com o resfriamento rápido da peça. Logo após este processo é comumente empregado o revenimento que permite a migração de parte do carbono para fora da martensita, melhorando a tenacidade do aço ao formar martensita revenida (FLINT et al., 1995; SILVA; MEI, 2006; CHIAVERINI, 2008).

O processo de resfriamento na têmpera em um meio fluido vaporizável sem agitação acontece normalmente em três estágios. Estes estágios da têmpera podem ser influenciados por diversos fatores, entre eles: agitação do meio, viscosidade, temperatura do meio, etc (TOTTEN et al., 1993). Estes estágios como indica a Figura 7, podem ser descritos como:

- no primeiro estágio $(A)$, uma camada de vapor se forma entre o fluido e o aço, fazendo com que a taxa de resfriamento seja menor, o que é indesejado, pois este encapsulamento limita as trocas de calor entre a peça e o meio, interferindo na formação de martensita;

- no segundo estágio (B), a camada de vapor, ao atingir certa temperatura se desfaz com o desprendimento de bolhas da superfície do aço. Este aparecimento e desprendimento de bolhas da superfície eleva as taxas de resfriamento do material, pois renova constantemente o fluido em contato com o aço;

- no terceiro estágio (C), o fluido encontra-se abaixo de seu ponto de ebulição, portanto a principal forma de resfriamento é por condução e convecção do fluido, proporcionando taxas de resfriamento menores que no segundo estágio. 
Figura 7. Mecanismos de resfriamento durante o processo de têmpera sem agitação.

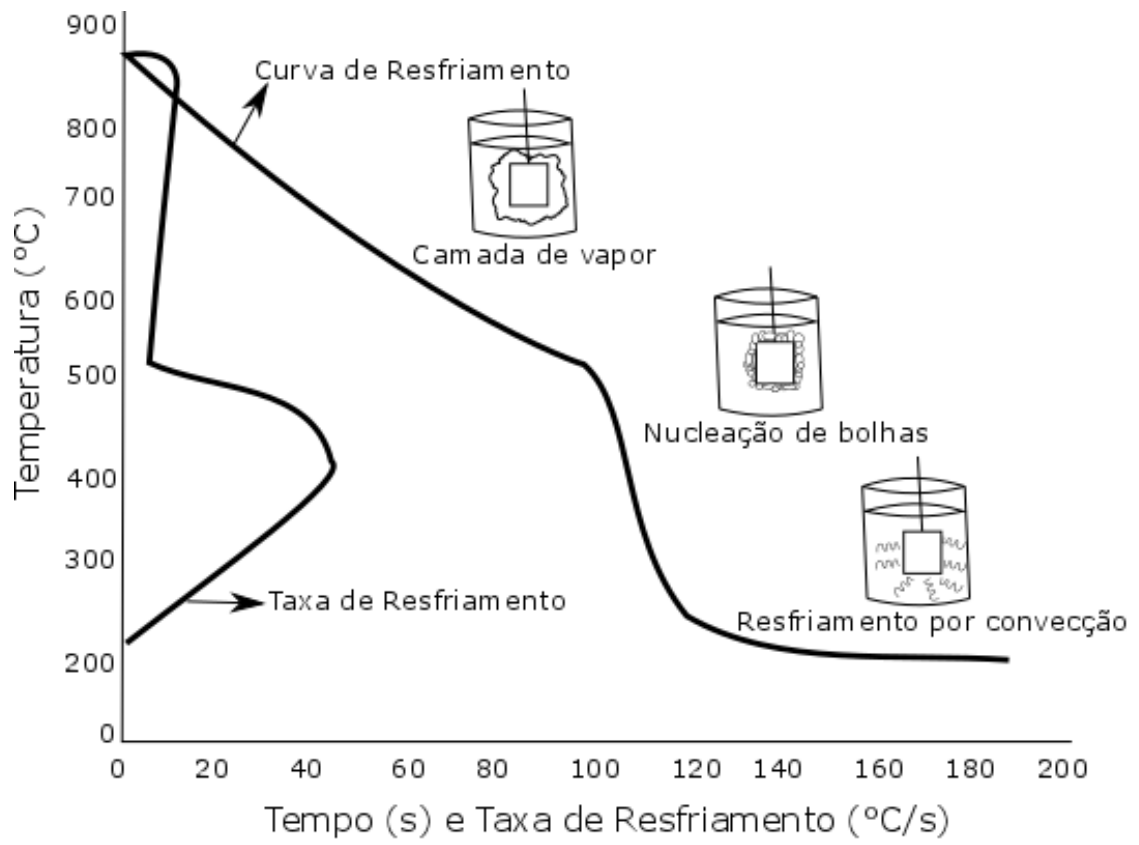

Fonte: Adaptado de TOTTEN et al., 1993.

As principais condições que afetam os resultados deste tratamento térmico são:

- Geometria da peça: seções maiores ou massas maiores implicam em maiores quantidades de calor a serem removidas, dificultando o resfriamento;

- Propriedades do meio de resfriamento;

- Atmosfera do forno, que sem controle pode causar descarbonetação da superfície, prejudicando a formação de martensita;

- Composição química da peça;

- Carbono e outros elementos de liga imprimem temperabilidade aos aços;

- Tempo e temperatura de austenitização (OTERO, 2014).

Os fluidos de resfriamento mais comuns utilizados neste processo são: ar, gás, água, óleo, solução polimérica, salmoura e sal fundido. Os óleos são muito utilizados como fluidos de resfriamento pois, apesar de produzirem menores taxas de resfriamento (comparados à água e salmoura), eles resfriam de forma mais uniforme promovendo menores distorções, reduzindo a chance de aparecimento trincas (FLINT et al., 1995; BROOKS, 1996).

Tipicamente, os fluidos mais modernos são originados do petróleo, (geralmente de base parafínica) quando formulados como fluidos de têmpera. Podem ser 
classificados de diversas formas, de acordo com o objetivo do tratamento e características da operação. As velocidades de resfriamento influenciam na dureza e também na profundidade que esta irá atingir. A Figura 8 indica diferentes classes de óleos minerais (lento, médio e rápido) utilizados para têmpera.

Parâmetros do banho, como já mencionado, exercem influência no desempenho do meio de têmpera, ou seja, na sua extração de calor (Figura 9). A temperatura tem também efeito na viscosidade e no potencial de promover distorções. A viscosidade tende a aumentar com o uso do óleo, causado por oxidação e degradação, que cria compostos de cadeias complexas e de maior ancoramento entre si, implicando na modificação das taxas de resfriamento permitidas pelo meio.

Figura 8. Curvas de resfriamento de diferentes óleos.

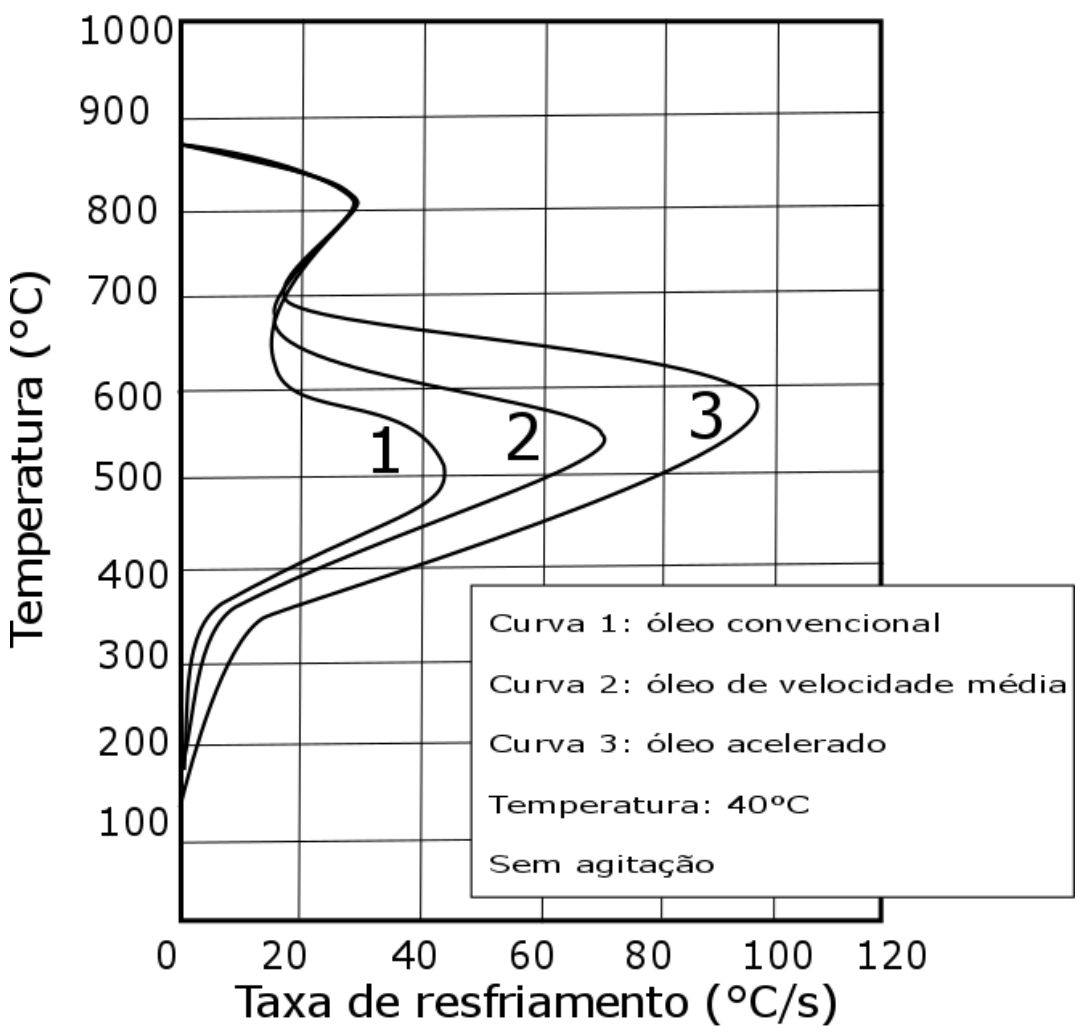

Fonte: Adaptado de FLINT et al., 1995. 
Figura 9.Curvas de resfriamento de óleo em diferentes temperaturas

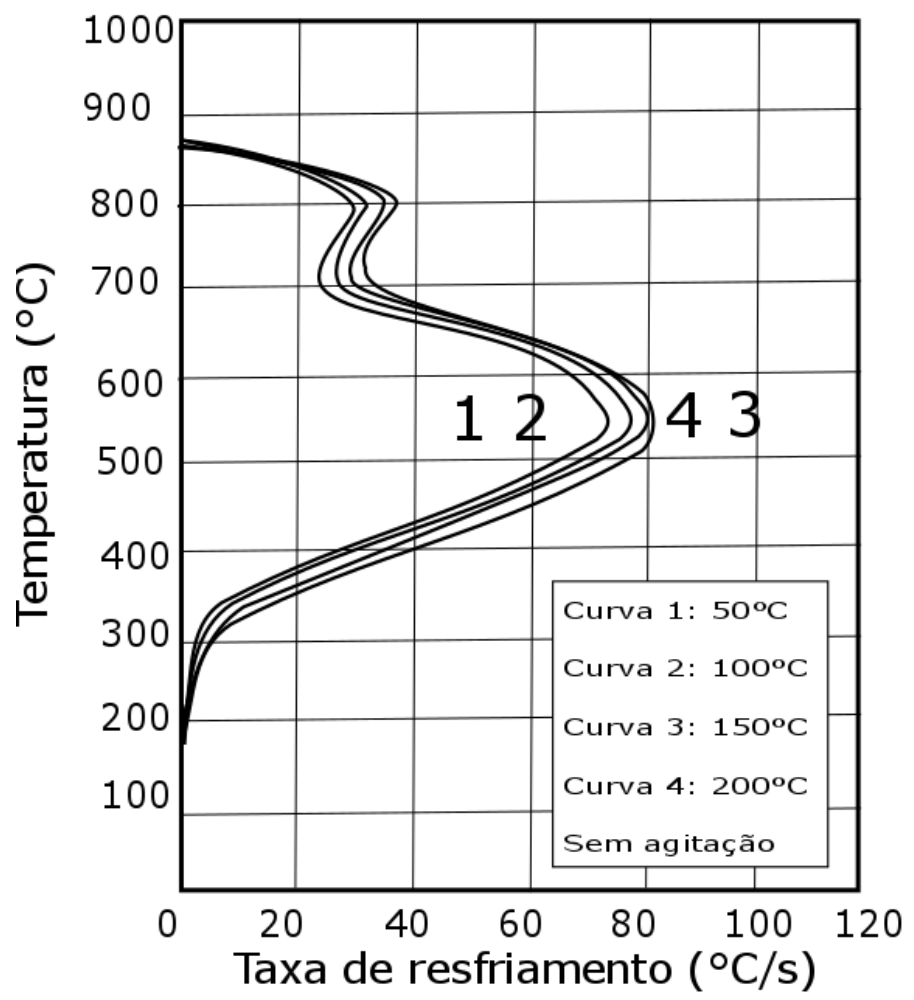

Fonte: Adaptado de FLINT et al., 1995.

\subsection{Coeficiente de transferência de calor}

Um dos melhores parâmetros para se caracterizar a transferência de calor entre o meio de resfriamento e o aço durante a tempera é o coeficiente de transferência de calor. Fluidos de maior severidade possuem maiores valores de coeficiente de transferência de calor. Este coeficiente pode ser calculado de inúmeras formas, as mais frequentes são modelos computacionais que utilizam elementos finitos e equações diferenciais, contudo são metodologias utilizadas para a coleta de dados enquanto o ensaio acontece (KOBASKO et al., 2010; OTERO, 2012).

Neste trabalho foi utilizado o método de Kobasko para o cálculo deste coeficiente, visto que ele pode ser calculado diretamente das curvas de resfriamento. Para isto foram extraídos das curvas de resfriamento as taxas de resfriamento a 700, 300 e $200^{\circ} \mathrm{C}$, bem como as propriedades geométricas e térmicas da sonda Inconel 600. A equação 7 indica o cálculo do número Kondratjev $\left(K_{n}\right)$ para que o número de Biot possa ser obtido de uma tabela, montada a partir da equação 8 , que correlaciona estes dois parâmetros (OTERO, 2012). 
Neste método de cálculo, o coeficiente de transferência de calor é obtido pelas seguintes equações:

$$
m=\frac{w}{T-T m}
$$

Onde:

$\mathbf{m}$ = é um parâmetro que reflete a velocidade de mudança de temperatura.

$\mathbf{T}=$ temperatura da sonda.

$\mathbf{T m}=$ temperatura do meio.

$\mathbf{w}=$ taxa de resfriamento para determinada temperatura.

$$
m_{\alpha}=\frac{a}{K}
$$

Onde:

$\mathbf{m}_{\boldsymbol{\alpha}}=$ parâmetro que reflete a velocidade de mudança de temperatura.

$\mathbf{k}=$ Fator Kondratjev (para cilindro calcula-se $\mathrm{R}^{2} / 5,783$.

$\mathbf{a}=$ difusividade térmica do metal.

$$
K_{n=\frac{m}{m \alpha}}
$$

$\mathbf{K n}=$ Número de Kondratjev.

$$
K_{n=\frac{B i_{v}}{\left(B i_{\nu}{ }^{2}+1,437 B i_{v}+1\right)^{0,5}}}
$$

Onde:

$B i_{v}=$ Número de Biot. 


$$
B i_{v}=\frac{\alpha K S}{\lambda V}
$$

$\mathbf{S}=$ superfície da sonda.

$\mathbf{V}=$ volume da sonda.

$\mathbf{k}=$ fator de Kondratjev.

$\lambda=$ condutividade térmica.

$\boldsymbol{\alpha}=$ coeficiente de transferência de calor.

Por meio da equação 11 pode-se obter o coeficiente de transferência de calor a em função do número de Biot:

$$
\alpha=\frac{\lambda V B i_{v}}{S K}
$$

Outro coeficiente utilizado para quantificar a severidade de meios de resfriamento é o Poder de Endurecimento (HP de Hardening Power). Definido por Segerberg, por meio de uma equação de regressão do gráfico presente na Figura 10 (TOTTEN et al., 1993). Este é um parâmetro calculado utilizando-se três transições de temperatura das curvas de resfriamento, equação 13.

$$
H P=91,5+1,34 T_{V P}+10,88 C R_{500-600}-3,85 T_{C P}
$$

Onde:

TVP = é a temperatura de transição do estágio A para o estágio B (vapor para ebulição).

$\mathbf{C R}_{500-600}=$ Taxa de resfriamento entre 500 e $600^{\circ} \mathrm{C}$.

TCP = é a temperatura de transição entre o estágio B e C (ebulição para convecção) 
Figura 10. Índice HP de óleos mineirais.

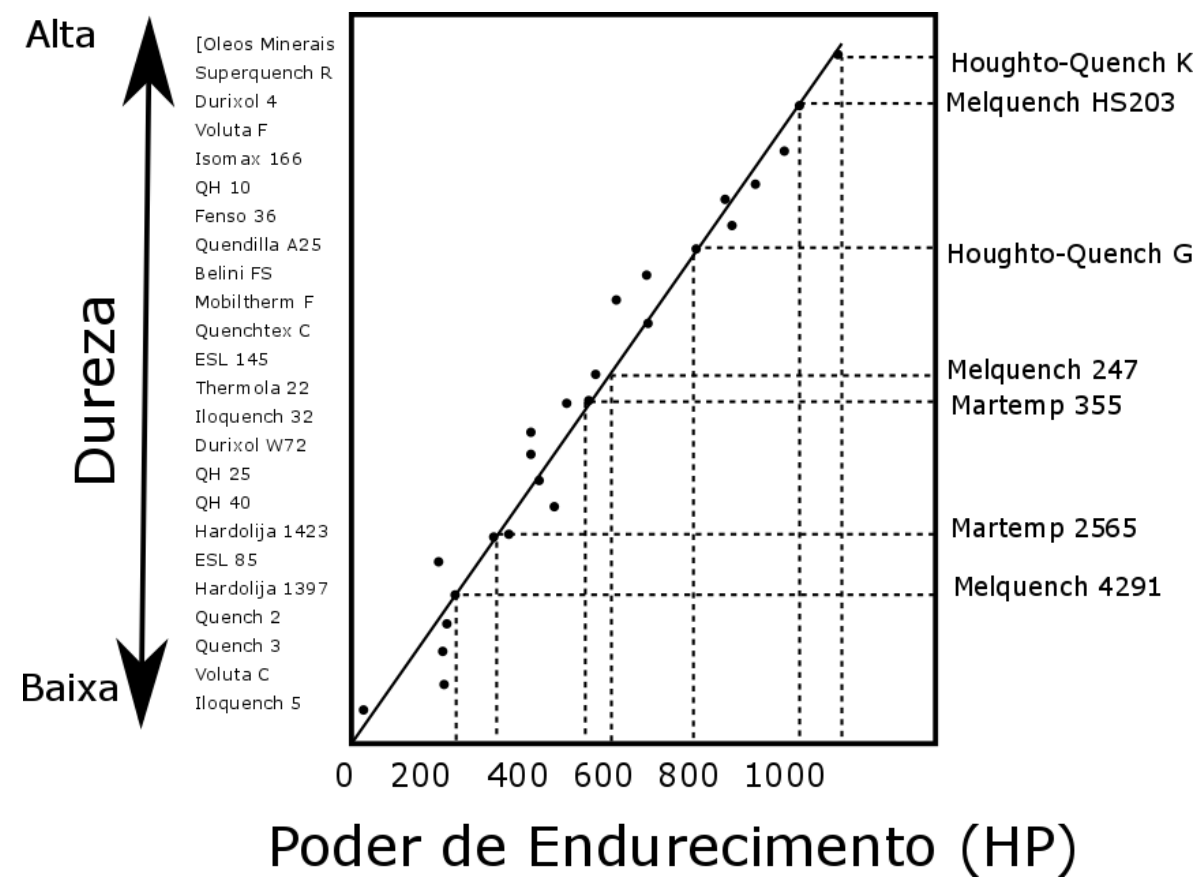

Fonte: Adaptado de TOTTEN et al., 1993.

Este algoritmo foi utilizado para classificar a severidade de temperas em óleos de diversas classes (convencional, acelerado, e óleos para martêmpera). Contudo, este foi designado especificamente para óleos e portanto, não deve ser utilizado para outros meios de resfriamento (TOTTEN et al., 1993; CHUN-HUAI; JING-EN, 2010). 


\section{MATERIAIS E MÉTODOS}

\subsection{Caracterização dos óleos vegetais}

Foram adquiridas amostras de óleo de girassol e soja, da marca Liza e produzido pela Cargill Agrícola S.A. (Lote: fab. 12/08/18 14:44 L09C e Fab. 20/09/18 15:39 L09P, respectivamente). Esta marca foi escolhida por não apresentar adição de antioxidantes, permitindo a análise em sua forma inalterada (OTERO, 2014). A amostra de óleo de oliva estudada é da marca Andorinha tipo extra-virgem (Lote: 244C L-8135623), por ser menos oxidado, visto que não passa por muitas etapas de refino.

A amostra de óleo de girassol alto oleico foi gentilmente doada pela Cargill Agrícola S/A. Este óleo é identificado, pela empresa, como AP81, Lote: PL1627 Fab. 23/09/2017.Já a amostra de óleo de soja epoxidado, doada pela empresa BBC Indústria e Comércio, é identificada como SOYFLEX 6250, Lote: LS 647/10 Fab 28/06/2010.

Para fins comparativos, foi escolhido o óleo mineral HKM (cód. 34242462-M) fornecido pela Houghton Brasil Ltda (Lote: 18172024).

A Tabela 4 a seguir indica as siglas ou nomes utilizados nas apresentações de resultados para cada óleo.

Tabela 4. Siglas e nomes utilizados para os fluidos de resfriamento estudados.

\begin{tabular}{ll}
\hline Fluidos de têmpera & Sigla \\
\hline Óleo de soja & SO \\
Óleo de soja epoxidado & ESBO \\
Óleo de girassol & Sun \\
Óleo de girassol alto oleico & HO Sun \\
Óleo de oliva & Olive \\
Óleo mineral & HKM \\
\hline
\end{tabular}

Fonte: Autoria própria.

Foram obtidos espectros de Ressonância Magnética Nuclear de Hidrogênio $\left(\mathrm{RMN}{ }^{1} \mathrm{H}\right.$ ) das amostras utilizando o equipamento Agilent Technology 500/54 Premium Shielded, de $500 \mathrm{MHz}$, temperatura de $26^{\circ} \mathrm{C}$. Os seguintes parâmetros foram empregados: tempo de relaxação de 15 segundos, pulso de $45^{\circ}$, tempo de aquisição 
de 6,554 segundos, largura espectral de $5000 \mathrm{~Hz}$ e 16 transientes para cada decaimento induzido livre.

As amostras foram preparadas a partir da solubilização de $120 \mathrm{mg}$ em $600 \mu \mathrm{L}$ de clorofórmio deuterado $\left(\mathrm{CDCl}_{3}\right)$ contendo $0,03 \%$ de tetrametilsilano (TMS) como referência interna. Os espectros obtidos foram tratados por meio do programa MestreNova.

As viscosidades cinemática das amostras de óleo foram determinadas utilizando um viscosímetro automático, da marca Herzog, modelo HVU 481, de acordo com a ASTM D445-18 (ASTM, 2018). As amostras foram inseridas no tubo capilar e condicionadas no banho termostatizado do equipamento por 15 minutos a $60^{\circ} \mathrm{C} \mathrm{e} \mathrm{em}$ seguida realizada a medição automática do equipamento.

\subsection{Curvas de resfriamento}

Para o levantamento das curvas de resfriamento, foi utilizada uma sonda cilíndrica padronizada feita de Inconel 600 (super-liga de níquel-cromo com resistência a altas temperaturas e à corrosão), com dimensões de $12,5 \mathrm{~mm}$ de diâmetro e $60 \mathrm{~mm}$ de comprimento, e, um termopar do tipo K posicionado no centro geométrico da sonda.

As curvas de resfriamento dos óleos estudados foram obtidas, em triplicatas, somente na temperatura de $60^{\circ} \mathrm{C}$, sem agitação, de acordo com a ASTM D6200 01(ASTM, 2001). A Figura 11 apresenta uma ilustração esquemática da sonda utilizada para obtenção das curvas de resfriamento. É válido ressaltar que as triplicatas foram feitas em sequência após a limpeza adequada da sonda e inspeção das temperaturas da sonda e do fluido de resfriamento.

Figura 11. Desenho técnico da montagem da sonda Inconel 600.

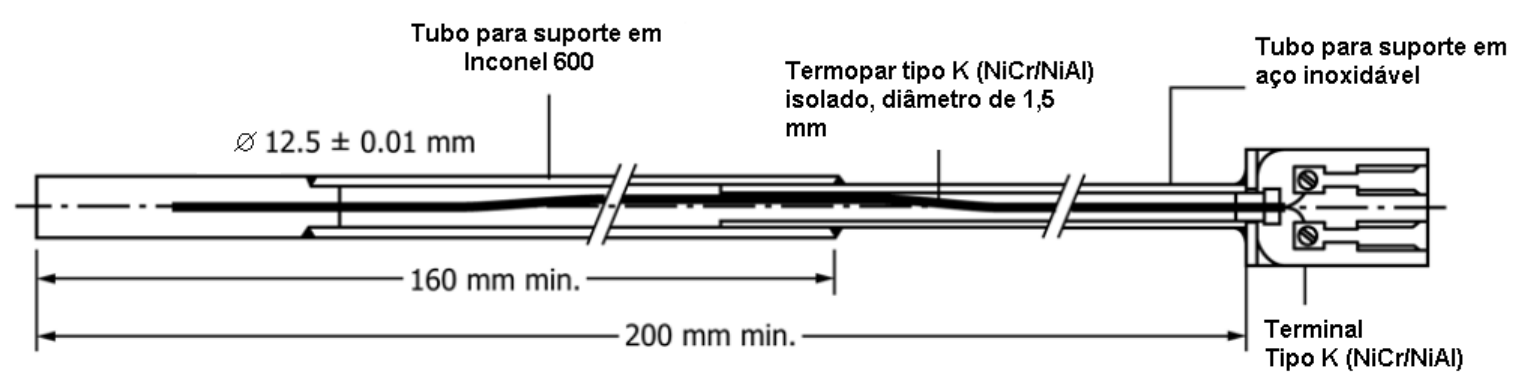

Fonte: adaptado de ASTM, 2001. 
A sonda foi aquecida em um forno até atingir $850^{\circ} \mathrm{C}$ e seguida mergulhada em um Becker de $2000 \mathrm{~mL}$ contendo o fluido a ser estudado $\left(\right.$ a $60^{\circ} \mathrm{C}$ ), dando início ao processo de resfriamento.

Para a coleta de dados como tempo de resfriamento e temperatura da sonda, foi utilizado o programa Labjack.

Os principais parâmetros utilizados na análise das curvas de resfriamento deste trabalho foram baseados nos parâmetros descritos na Figura 12.

Figura 12. Parâmetros das curvas de resfriamento.

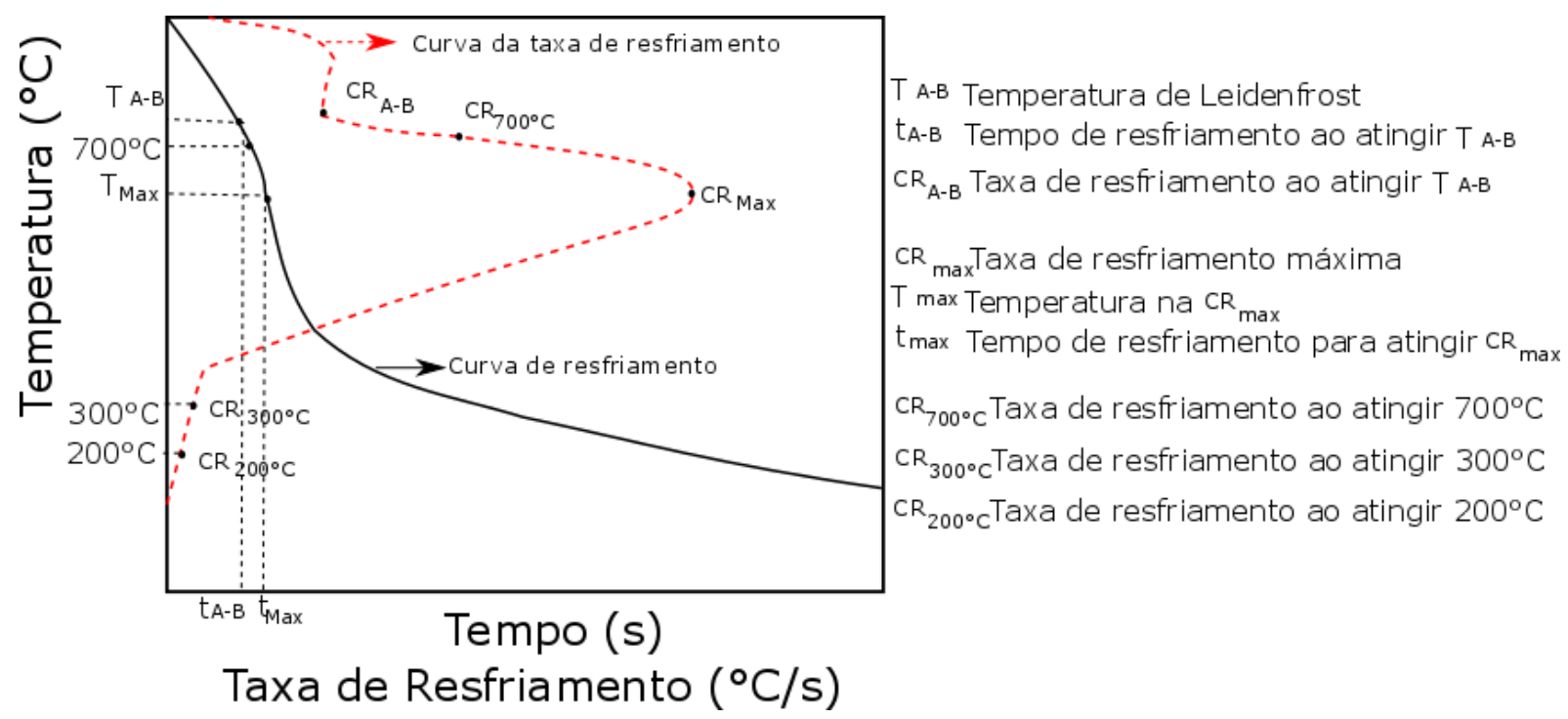

Fonte: Adaptado de TOTTEN et al., 1993.

Os parâmetros de Leidenfrost caracterizam a transição do estágio A para o B, ou seja, rompimento da camada de vapor. Geralmente, é desejado aumentar a taxa de resfriamento a $700^{\circ} \mathrm{C}$ e reduzir o tempo de $700-230^{\circ} \mathrm{C}$, reduzindo a formação de perlita. Contudo, menores taxas de resfriamento nas temperaturas de 300 a $200^{\circ} \mathrm{C}$ são almejadas, evitando excessiva distorção e aparecimento de trincas em peças de alta temperabilidade (TOTTEN et al., 1993).

\subsection{Análise Metalúrgica do aço SAE 1045 após têmpera}

Com o intuito de averiguar a resposta metalúrgica dos fluidos utilizados, amostras de SAE 1045 foram cortadas nas dimensões de uma polegada de diâmetro 
por uma polegada de comprimento (ø1"x1"), apesar de não ser o tamanho ideal (normalmente 4 x o diâmetro) para levantamentos de curvas de dureza em "U".

De forma a comprovar se o material adquirido era compatível às especificações de composição química de um aço SAE 1045, foi utilizada a técnica de Espectrometria de Emissão Óptica por Centelhamento (equipamento da marca Anacom Científica B2Avanced).

Após a certificação da composição, os corpos de prova foram normalizados previamente ao processo de têmpera, promovendo homogeneização da microestrutura e composição química, apagando o histórico térmico do material adquirido. Este tratamento foi conduzido aquecendo-se o metal até $850^{\circ} \mathrm{C}$ por duas horas e resfriando ao ar. Após a normalização, estas amostras foram então submetidas à têmpera, usando como meios de resfriamento os óleos vegetais mencionados e o óleo mineral acelerado.

Os corpos de prova foram colocados em uma caixa de metal coberta com carvão (minimizando a descarbonetação, devido à indisponibilidade de um forno com atmosfera controlada) em um forno elétrico da EDG Equipamentos, modelo FL-1300 com controlador FE50RPN da Flyever. O material foi mantido por duas horas a $850^{\circ} \mathrm{C}$ (compatível com a temperatura de austenitização de um aço carbono com 0,45\%) e resfriado ao ar (SIEBERT et al., 1977)

A temperatura e quantidade de fluidos de resfriamento foram os mesmos que utilizados para a sonda Inconel (2 litros e $60^{\circ} \mathrm{C}$ ). Após a austenitização, os corpos de prova foram retirados do forno e imediatamente resfriados nos fluidos estudados, na condição sem agitação.

Após a têmpera, os corpos de prova de SAE 1045 foram seccionados ao meio na transversal em uma máquina de erosão a fio, garantindo planicidade e paralelismo das faces. Em seguida, foram lixados com lixa 80 mesh até a remoção das marcas da erosão. A macrodureza foi medida com base na norma ASTM E18 (ASTM, 2019) utilizando-se um durômetro da marca Wilson modelo 4JR e penetrador cônico de diamante Holterman de $120^{\circ}$ MPA NRW. As posições das medidas foram as seguintes: superfície $(S)$, metade do raio do corpo de prova $(1 / 2 r)$, um quarto do raio $(1 / 4 r)$ e centro $(C)$, Figura 13. 
Figura 13. Indicações das posições utilizadas para dureza Rockwell na curva em U.

$1 "$

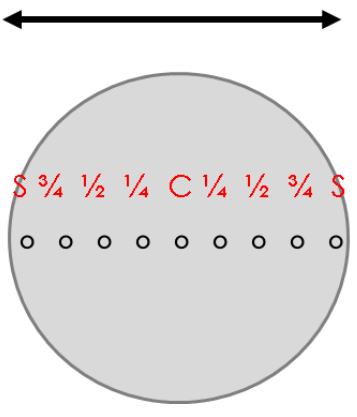

Fonte: Autoria própria.

Os corpos de prova para o ensaio de dureza foram embutidos em baquelite em pó da marca Arotec, lixados com lixas d'água Norton 120 a 1200 mesh e polidos em óxido de cromo. Após o ataque em Nital $2 \%$, por cerca de 10 segundos, foi realizada a análise microestrutural. Esta foi conduzida utilizando um microscópio da Olympus, modelo BX-41 M, com câmera TCa-1.3C acoplada e software de aquisição TSview.

Adicionalmente, o software Image $J$ foi utilizado para o tratamento das metalografias no cálculo do teor de martensita formada na superfície das amostras temperadas, para isto, ampliações de 50x foram empregadas, visto que estas ofereciam melhor contraste e boa representatividade da região em que a medida de dureza foi realizada na superfície (indicada como S na Figura 13).

Na Figura 14 encontra-se um fluxograma do processo de análise dos materiais estudados neste trabalho, sumarizando as etapas previamente descritas. 
Figura 14. Metodologia empregada neste trabalho para a análise dos materiais.

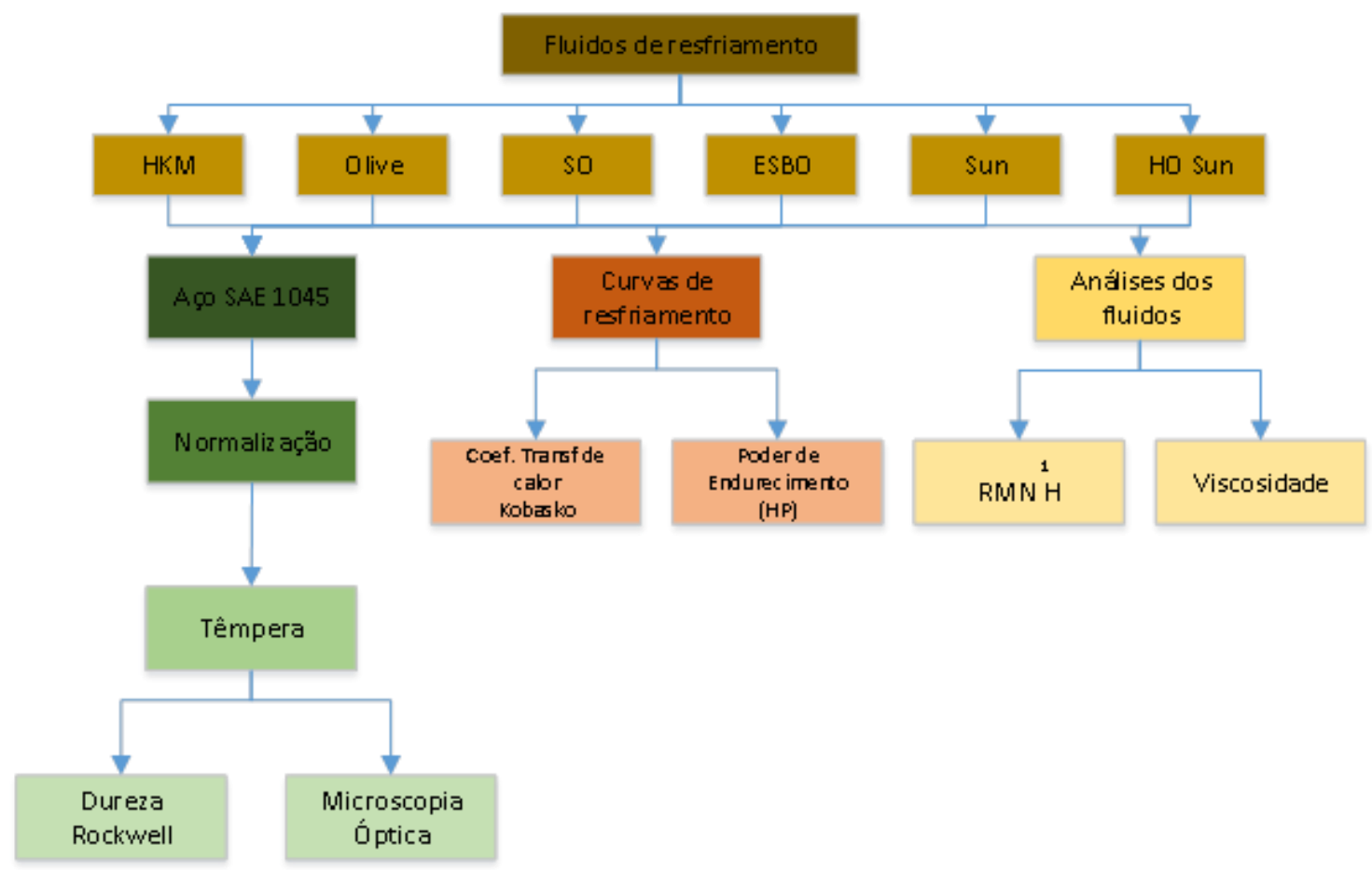

Fonte: Autoria própria. 


\section{RESULTADOS E DISCUSSÕES}

\subsection{Caracterização dos óleos vegetais}

As Figuras 15 a 19 indicam os espectros de RMN ${ }^{1} \mathrm{H}$ obtidos para os óleos vegetais analisados neste trabalho.

Para o caso do óleo de soja epoxidado compostos mono, di e triepóxidos, podem ser formados durante a reação de epoxidação. Nos espectros da Figura 15 e 16, observa-se diferenças entre os sinais entre o óleo de soja e o óleo modificado quimicamente. Para este caso, os sinais $\mathrm{K}$ e L são hidrogênios de carbonos de anéis oxirânicos, formados após a reação de epoxidação. Já o sinal $\mathrm{M}$, pode ser atribuído à formação de hidrogênios metílicos terminais presentes em composto triepóxido. Ainda nesta comparação, é válido ressaltar que para o sinal $A$, existe uma redução, pois conforme já mencionado, após a epoxidação as insaturações se transformam em anéis epóxidos (OTERO, 2014).

Figura 15. Espectro $\mathrm{RMN}{ }^{1} \mathrm{H}$ do óleo de soja.

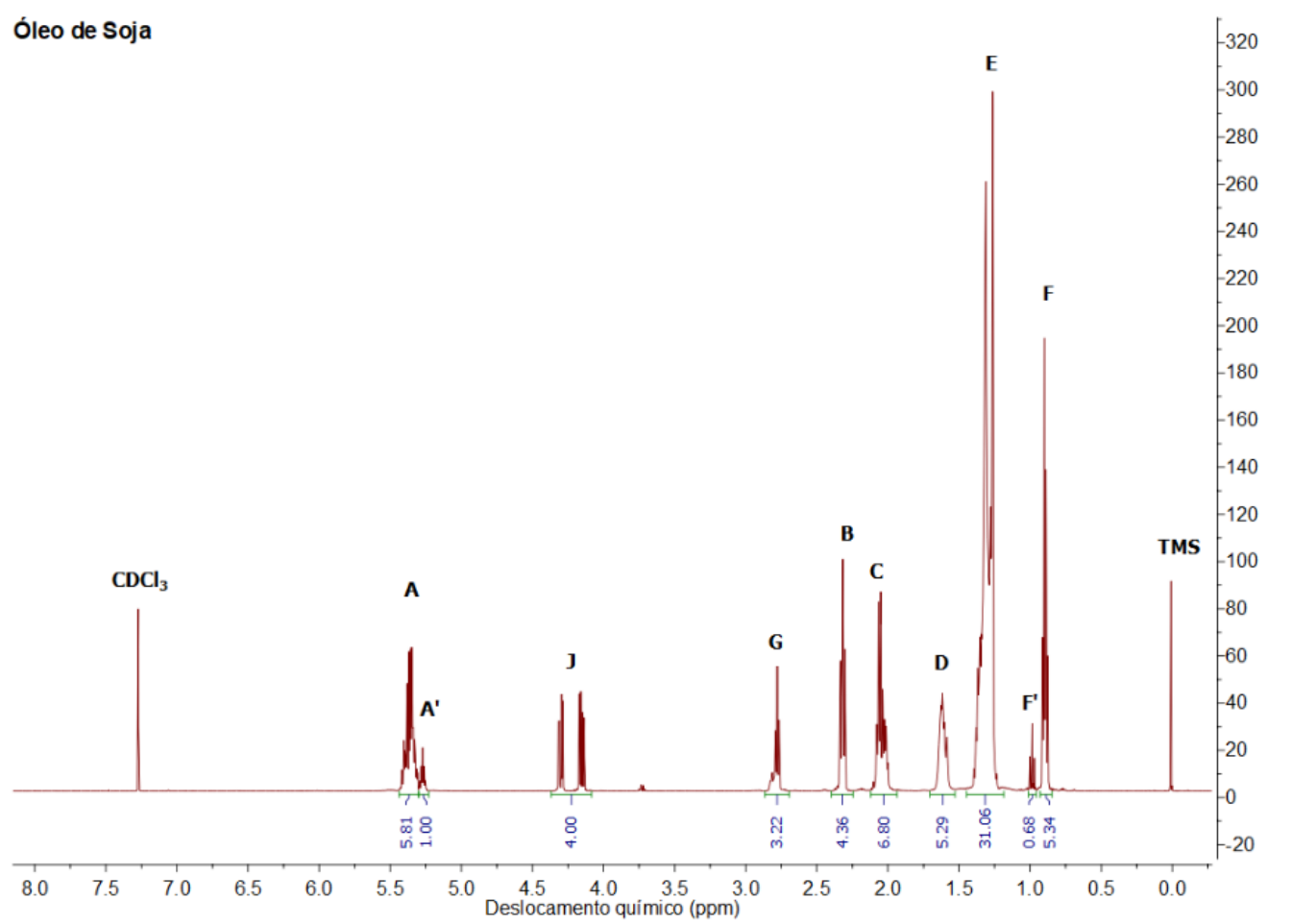

Fonte: Autoria própria. 
Figura 16. Espectro RMN ${ }^{1} \mathrm{H}$ do óleo de soja epoxidado.

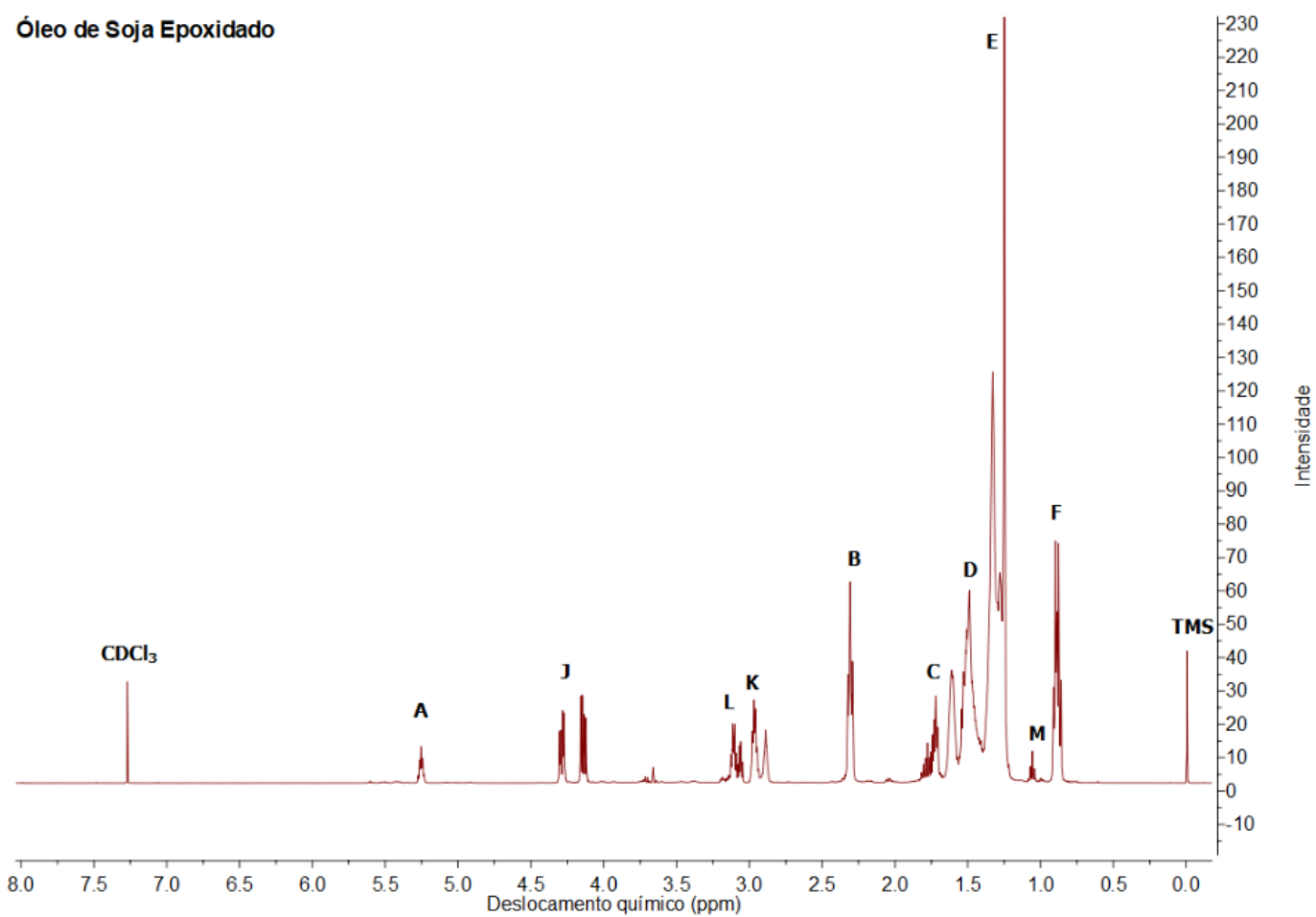

Fonte: Autoria própria.

Comparando-se os óleos de girassol e girassol alto oleico (Figuras 17 e 18), observa-se o sinal $G$ muito menor e desaparecimento do $F$ ', que representam hidrogênios dos grupos metilenos relacionados à presença de poli-insaturações. Indicando que a as sementes de girassol modificadas geneticamente para tal função produzem óleos com teores de ácido oleico superiores aos extraídos de sementes comuns. 
Figura 17. Espectro $\mathrm{RMN}{ }^{1} \mathrm{H}$ do óleo de girassol.

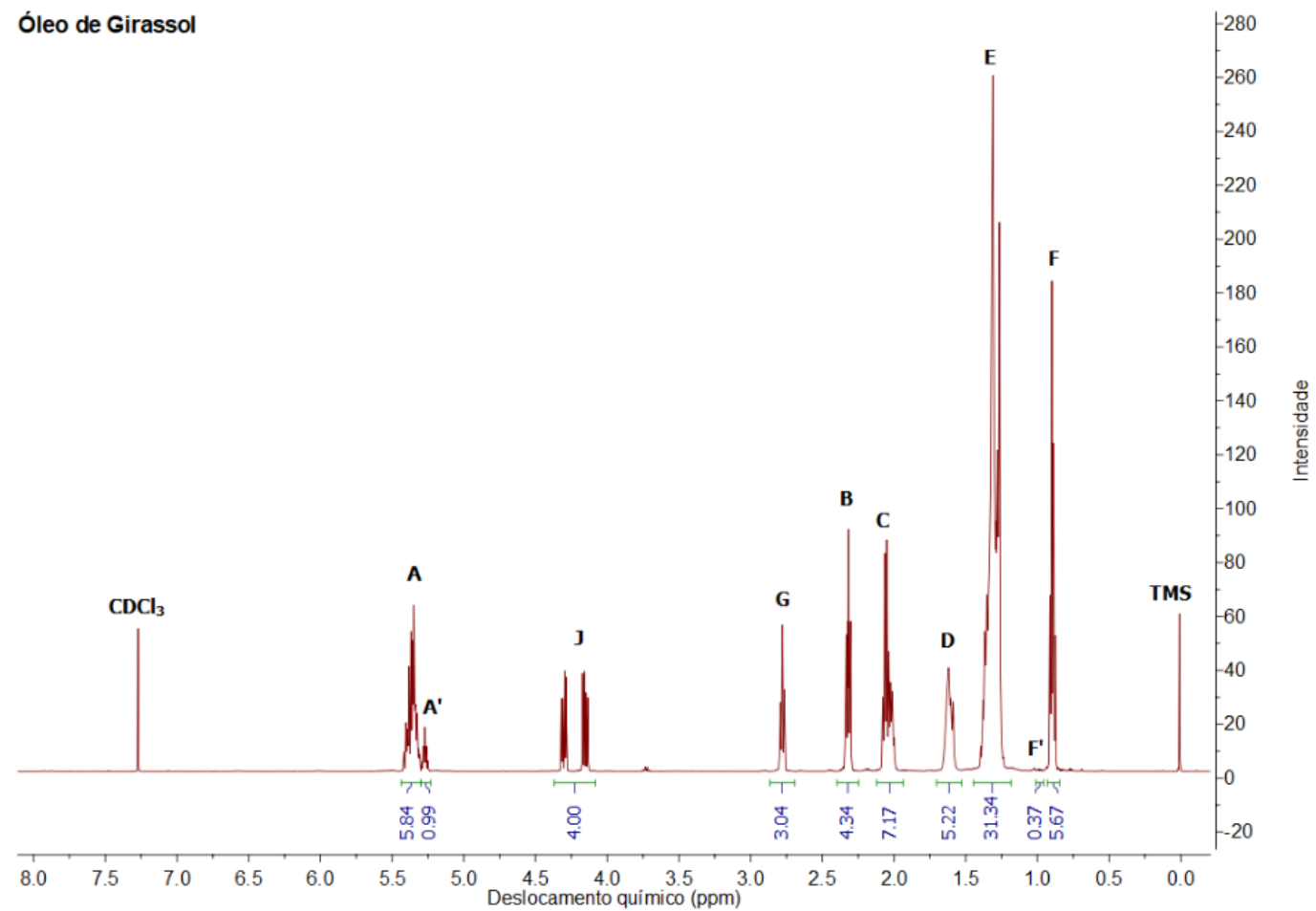

Fonte: Autoria própria.

Figura 18. Espectro $\mathrm{RMN}{ }^{1} \mathrm{H}$ do óleo de girassol alto oleico.

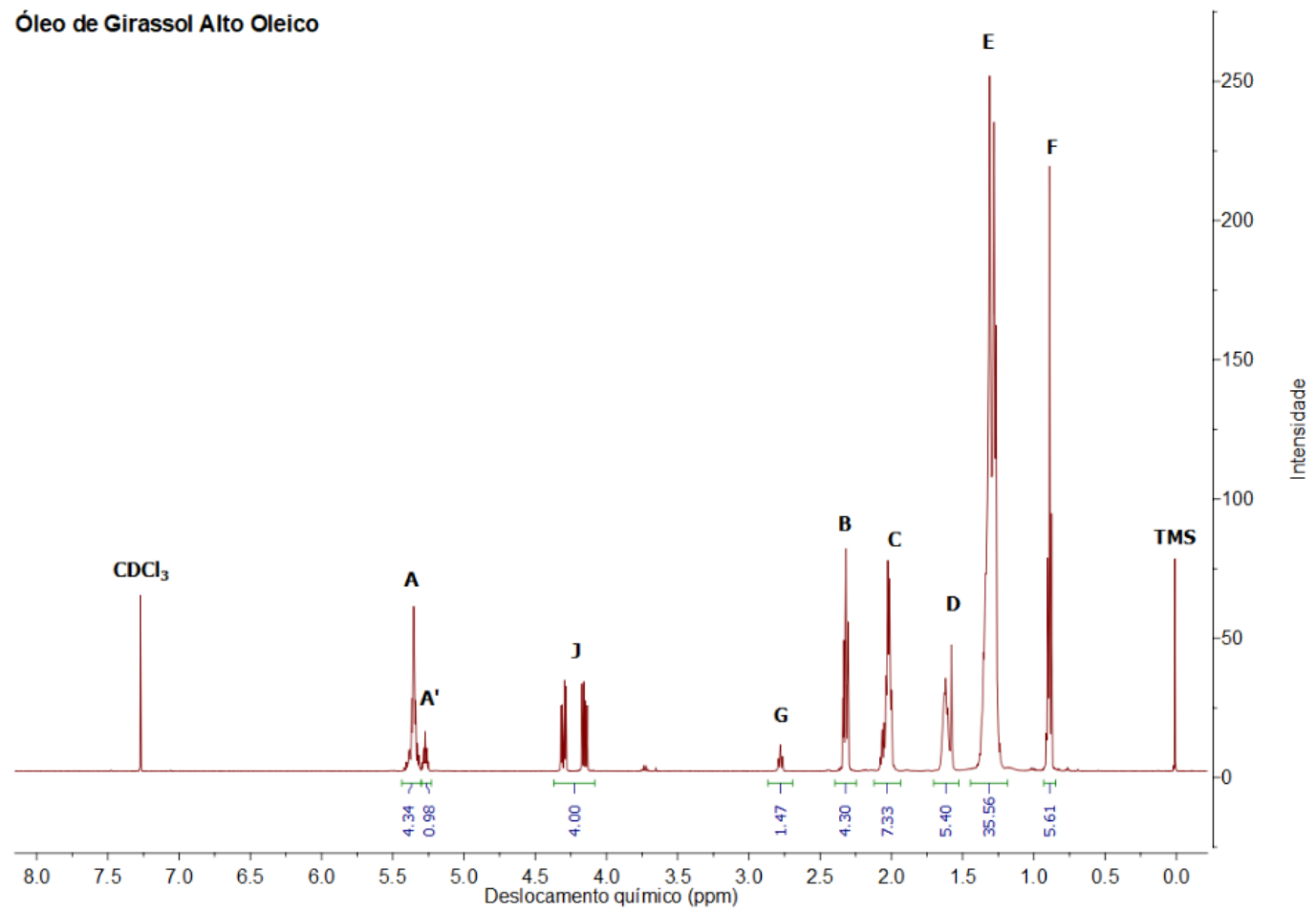

Fonte: Autoria própria. 
A Figura 19 indica o espectro obtido para o óleo de oliva. Quando comparado aos outros óleos vegetais analisados, este se assemelha ao óleo de girassol alto oleico (Figura 18) indicando perfis de AG parecidos.

Figura 19. Espectro $\mathrm{RMN}{ }^{1} \mathrm{H}$ do óleo de oliva.

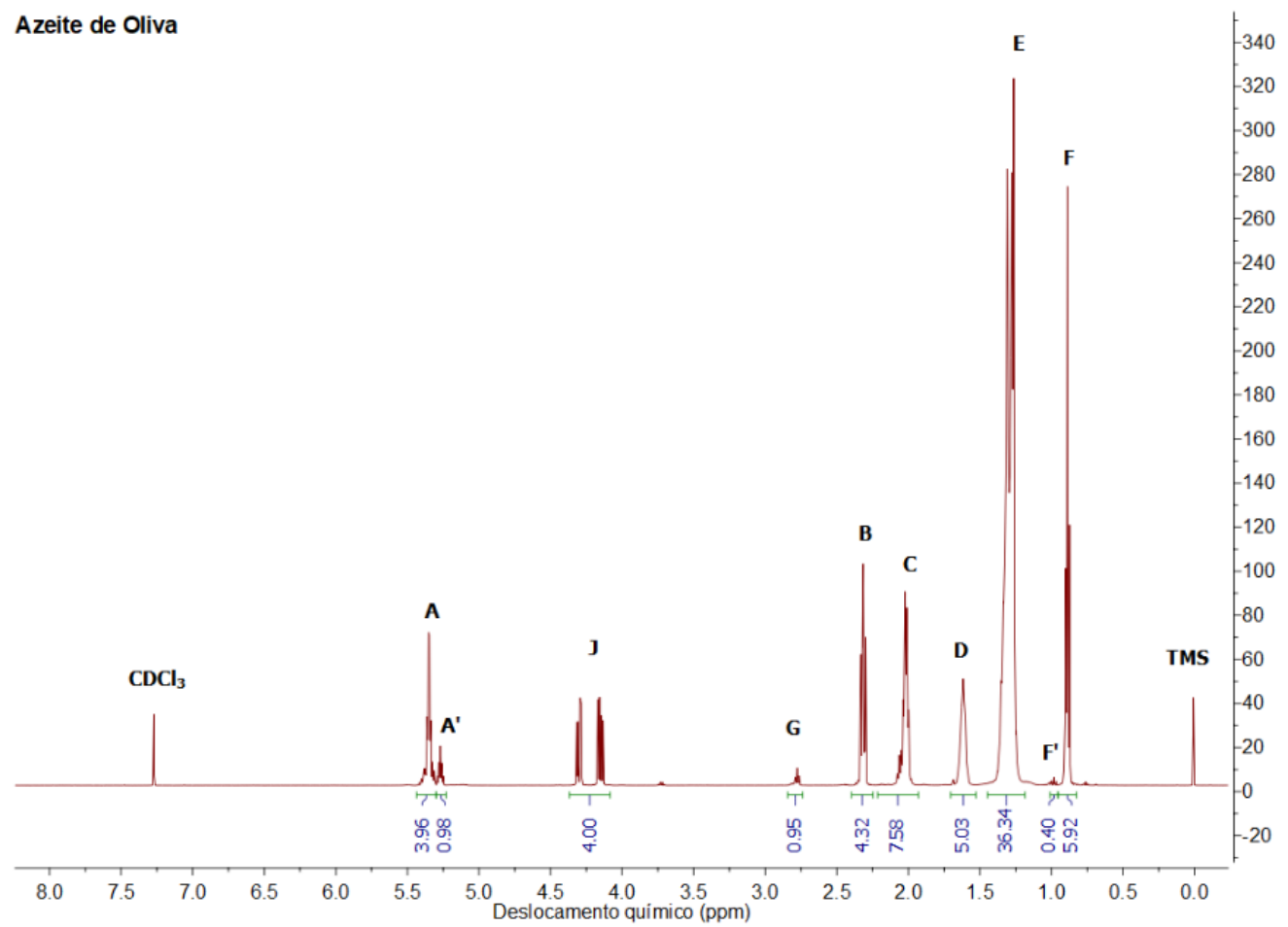

Fonte: Autoria própria.

A Tabela 6 indica os resultados extraídos do espectro RMN ${ }^{1} \mathrm{H}$. Comparandose os teores de AG dos óleos estudados com os teores apresentados pela referência, Tabela 5, observa-se boa correlação (ADHVARYU et al., 2000; GUILLÉN; RUIZ, 2003). Adicionalmente, nota-se um teor de ácido linolênico um pouco maior para a amostra de óleo de girassol do que para as apresentadas na referência, isto se deve à região e/ou variedade das sementes utilizadas na extração do óleo. As massas molares se mostraram parecidas e com valores próximos aos esperados para óleos vegetais (BOCKISCH, 1998). 
Tabela 5. Teores de ácidos graxos em diferentes óleos vegetais.

\begin{tabular}{ccccc}
\hline \multirow{2}{*}{ Óleos vegetais } & \multicolumn{4}{c}{ Teores de ácidos graxos } \\
\cline { 2 - 5 } & Saturados & Oleico & Linoleico & Linolênico \\
\hline Oliva & 14,5 & 75,5 & 7,5 & 1 \\
Girassol alto oleico & 9,0 & 75,0 & 16,0 & 0 \\
Girassol & 12,0 & 23,0 & 63,0 & $<0,5$ \\
Soja & 15,5 & 21,0 & 53,0 & 8,0 \\
\hline
\end{tabular}

Fonte: adaptado de GUILLÉN, 2003.

Tabela 6. Propriedades obtidas pelo espectro de RMN ${ }^{1} \mathrm{H}$ dos óleos vegetais.

\begin{tabular}{ccccccc}
\hline Amostra & IV & MM & Ln(\%) & L(\%) & O(\%) & S(\%) \\
\hline Óleo de Soja & 125,0 & 873 & 11,3 & 51,3 & 15,4 & 22,0 \\
Óleo de Girassol & 124,9 & 873 & 6,1 & 57,8 & 18,7 & 17,4 \\
Óleo de Girassol Alto Oleico & 92,9 & 859 & 0,0 & 34,2 & 51,0 & 14,8 \\
$\quad$ Óleo de Oliva & 84,6 & 856 & 6,3 & 9,3 & 72,1 & 12,3 \\
Legenda: IV - Índice de lodo; MM - Massa molar; Ln - Ácido Linolênico; L-Ácido Linoleico; O-Ácido Oleico e S \\
- Ácido Graxo Saturado.
\end{tabular}

Fonte: Autoria própria.

Comparando-se os óleos vegetais, foi possível constatar que:

- o maior teor de ácido oleico foi encontrado no óleo de oliva, este ainda apresenta menor teor de AG poli-insaturados que o óleo de girassol alto oleico, o que the confere um índice de iodo inferior;

- o óleo de girassol alto oleico que apresentou teores de ácido oleico muito superiores ao óleo de girassol comum (mais que o dobro);

- os óleos de soja e de girassol apresentaram os maiores teores de ácidos graxos poli-insaturados entre os óleos vegetais. Portanto, estes apresentam os maiores índices de iodo, consequentemente são mais propensos a degradação que os outros óleos analisados;

- a massa molar dos óleos é relativamente parecida, contudo, propriedades físicas como a viscosidade não podem ser assumidas semelhantes, uma vez que estes fluidos apresentam perfis de AG muito diferentes. 
A Tabela 7 apresenta as viscosidades obtidas para os óleos vegetais a $60^{\circ} \mathrm{C}$, que é a temperatura escolhida para os meios de resfriamento na têmpera do aço SAE 1045 e levantamento das curvas de resfriamento com a sonda Inconell 600.

Os valores obtidos se mostraram compatíveis aos encontrados na literatura e normalmente a $60^{\circ} \mathrm{C}$ os óleos vegetais (sem modificações químicas) exibem viscosidades cinemáticas por volta de 20 cSt (ADHVARYU et al., 2000; OTERO et al., 2017). O óleo de soja epoxidado apresentou valores um pouco superiores aos encontrados na literatura, 66, 7 cSt. Estas diferenças observadas são decorrentes de inúmeros fatores, como: variedade das sementes empregadas na extração do óleo, tratamentos químicos empregados pelo fabricante e oxidação pela exposição ao ar, luz ou presença de contaminantes metálicos.

Nota-se que o óleo de soja epoxidado apresentou viscosidade muito superior aos outros óleos, o que acarreta em taxas de resfriamento menores. Entre os óleos vegetais sem modificações químicas os maiores valores são do óleo de oliva e girassol alto oleico. É válido ressaltar que o óleo em contato com o metal encontra-se a temperaturas superiores a $60^{\circ} \mathrm{C}$, fazendo com que a viscosidade seja alterada, assim como o comportamento do meio de resfriamento.

Tabela 7. Viscosidade a $60^{\circ} \mathrm{C}$ dos óleos vegetais estudados neste trabalho e comparados à referência.

\begin{tabular}{lcc}
\hline \multicolumn{1}{c}{ Tipo de óleo } & Viscosidade medida (cSt) & $\begin{array}{c}\text { Referência } \\
\text { (cSt) }\end{array}$ \\
\hline Óleo de Soja & 17,6 & 17,8 \\
Óleo de Soja Epoxidado & 82,8 & 66,7 \\
Óleo de Girassol & 17,7 & 16,4 \\
Óleo de Girassol Alto Oleico & 21,2 & 24,0 \\
Óleo de Oliva & 20,4 & 21,4 \\
Óleo Mineral Acelerado & 6,9 & 7,48 \\
\hline
\end{tabular}

Fonte: BROCK et al., 2008; QUINCHIA et al., 2009; OTERO et al., 2017.

O óleo mineral foi o que exibiu menor valor de viscosidade à $60^{\circ} \mathrm{C}$, em torno de 7 cSt. Normalmente, fluidos de baixa viscosidade oferecem maior molhabilidade ao aço na têmpera e facilidade de rompimento da camada de vapor. Contudo, esta camada isolante também é afetada pelo teor de voláteis presentes no meio de 
resfriamento, que é tipicamente maior em óleos minerais, acarretando em um rompimento mais lento da camada de vapor.

\subsection{Curvas de Resfriamento}

A seguir são apresentadas nas Figuras 20 a 25 as curvas de resfriamento dos fluidos estudados neste trabalho. Nota-se uma tendência do óleo de soja na redução da CRmax (Figura 20), ou seja, o 'nariz' da curva da taxa de resfriamento é "empurrado" para a esquerda do gráfico após a realização de cada curva. Observa-se também que as temperaturas da transição do estágio A para o B se mantiveram parecidas, porém do estágio B para $\mathrm{C}$ acontece um aumento.

Figura 20. Curvas de Resfriamento do óleo de soja.
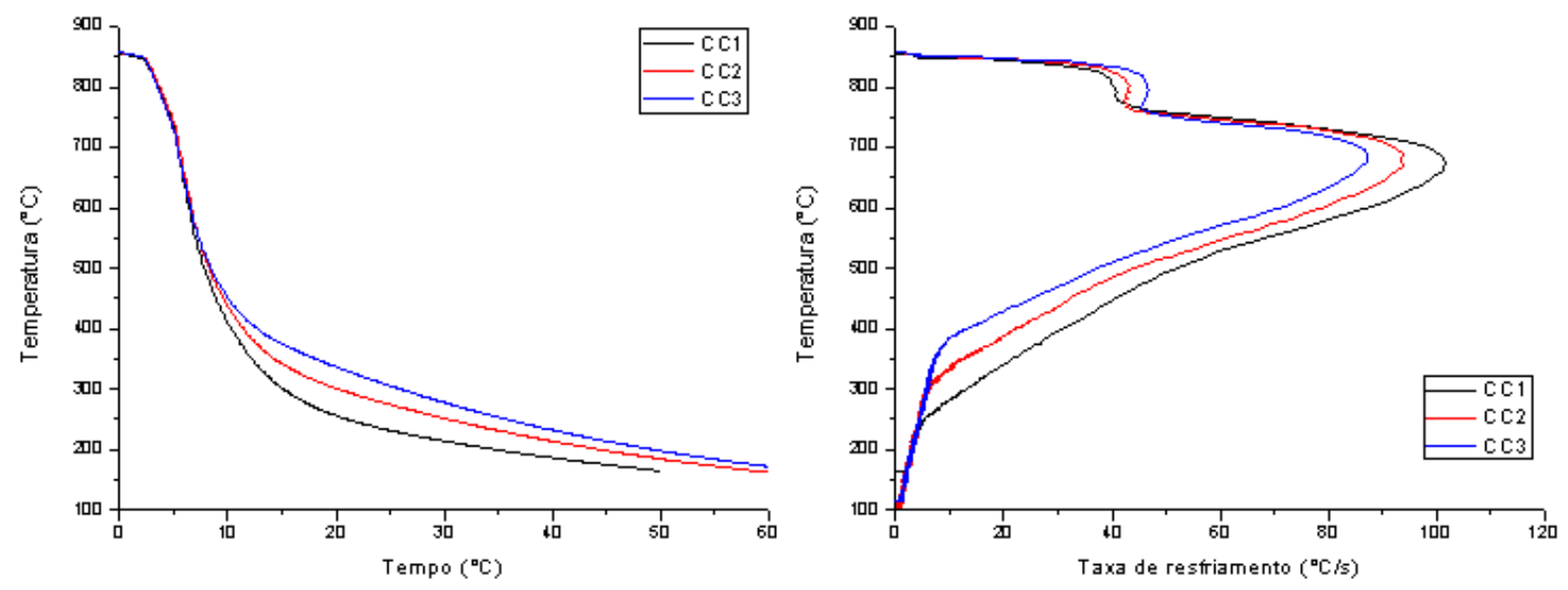

Fonte: Autoria própria.

Para o caso do óleo de girassol, Figura 21, o mesmo efeito foi observado. Infelizmente, não foram conduzidas análises dos óleos após o levantamento das curvas de resfriamento, impossibilitando provar que estes óleos apresentaram degradação e/ou emissão de voláteis. Contudo, este comportamento pode ser explicado pelo elevado teor de AG poli-insaturados, aumentando a instabilidade quando submetido a elevadas temperaturas, corroborando para a hipótese que de que estes dois óleos sofrem modificações significativas. 
Figura 21. Curvas de Resfriamento do óleo de girassol.
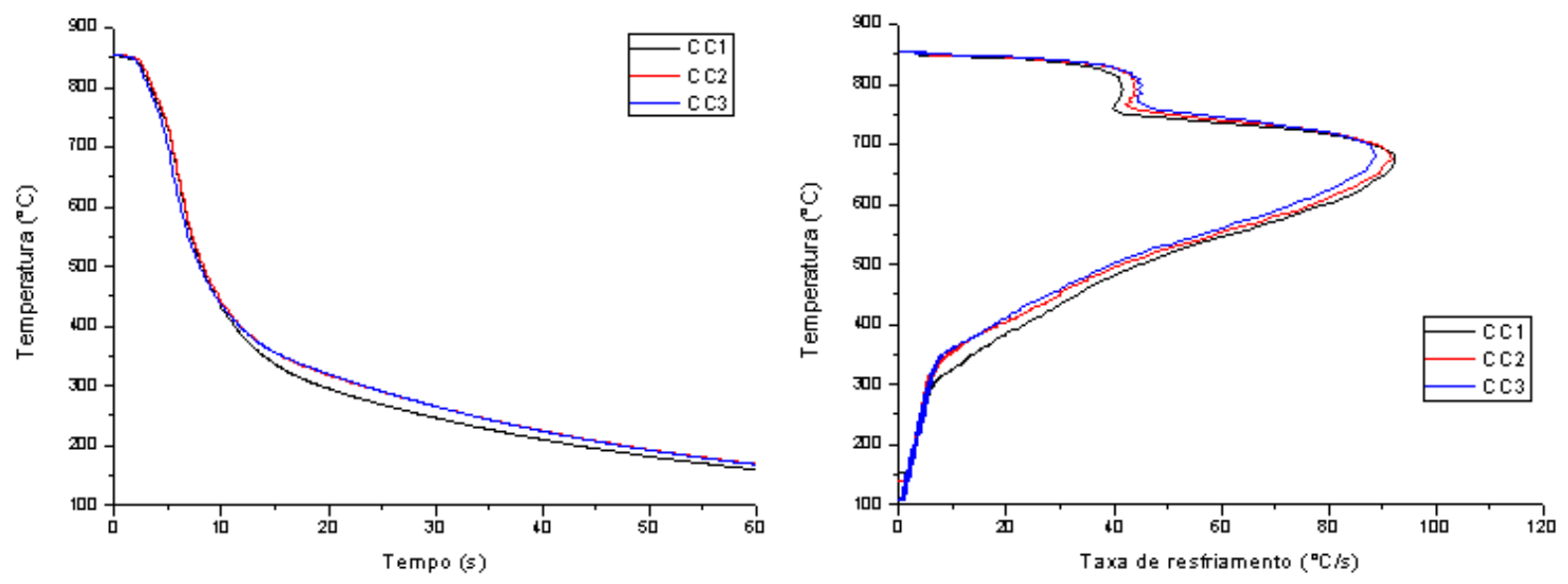

Fonte: Autoria própria.

Comparando-se os óleos de soja e de soja epoxidado (Figuras 20 e 22, respectivamente), tem-se uma redução da taxa máxima de resfriamento, aumento da temperatura de transição do estágio $A$ para o $B$, enquanto que a transição de $B$ para C se mantém inalterada. A redução da taxa máxima pode ser explicada pela viscosidade superior do óleo modificado quimicamente, que é uma das maiores desvantagens deste tratamento. Contudo, este oferece rompimento da camada de vapor expressivamente mais rápido.

Figura 22. Curvas de Resfriamento do óleo de soja epoxidado.
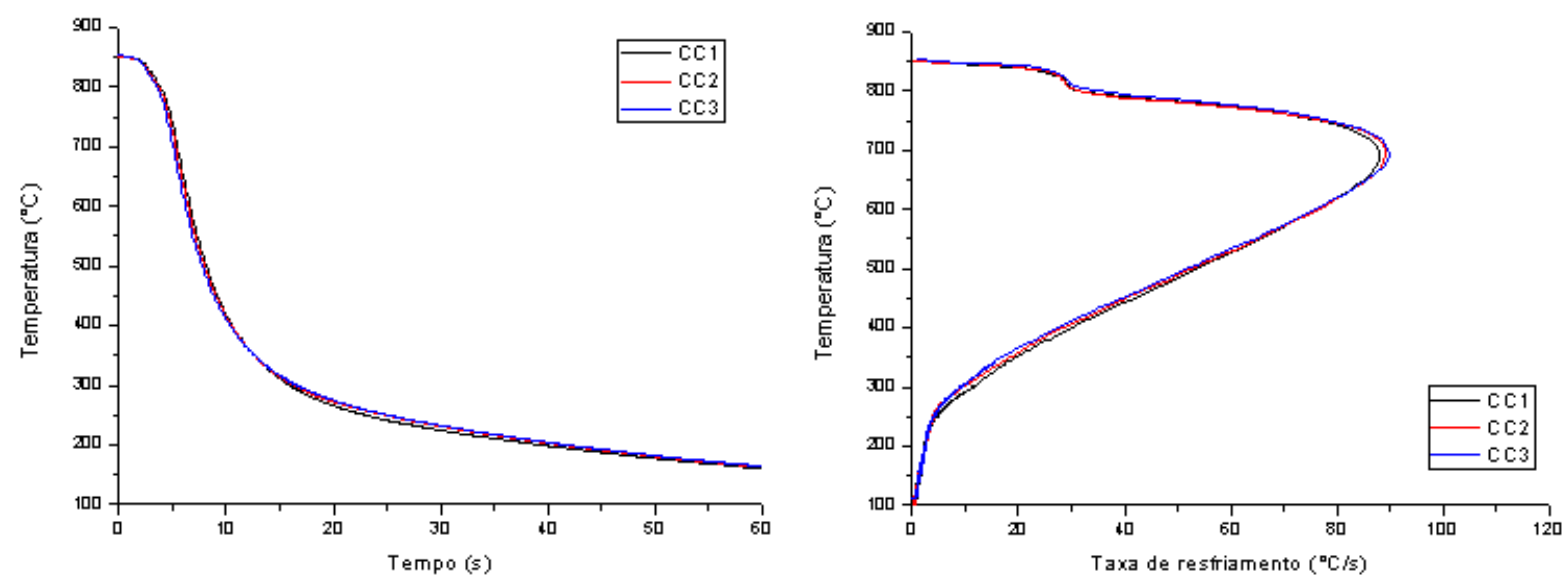

Fonte: Autoria própria. 
Quando comparados os óleos de girassol e girassol alto oleico (Figuras $21 \mathrm{e}$ 23, respectivamente) observa-se que a transição do estágio A-B é essencialmente a mesma, porém existe uma queda na taxa máxima de resfriamento, podendo ser justificada pela viscosidade superior do alto oleico. Também notou-se um aumento considerável da temperatura de transição de do estágio B-C..

Figura 23. Curvas de Resfriamento do óleo de girassol alto oleico.
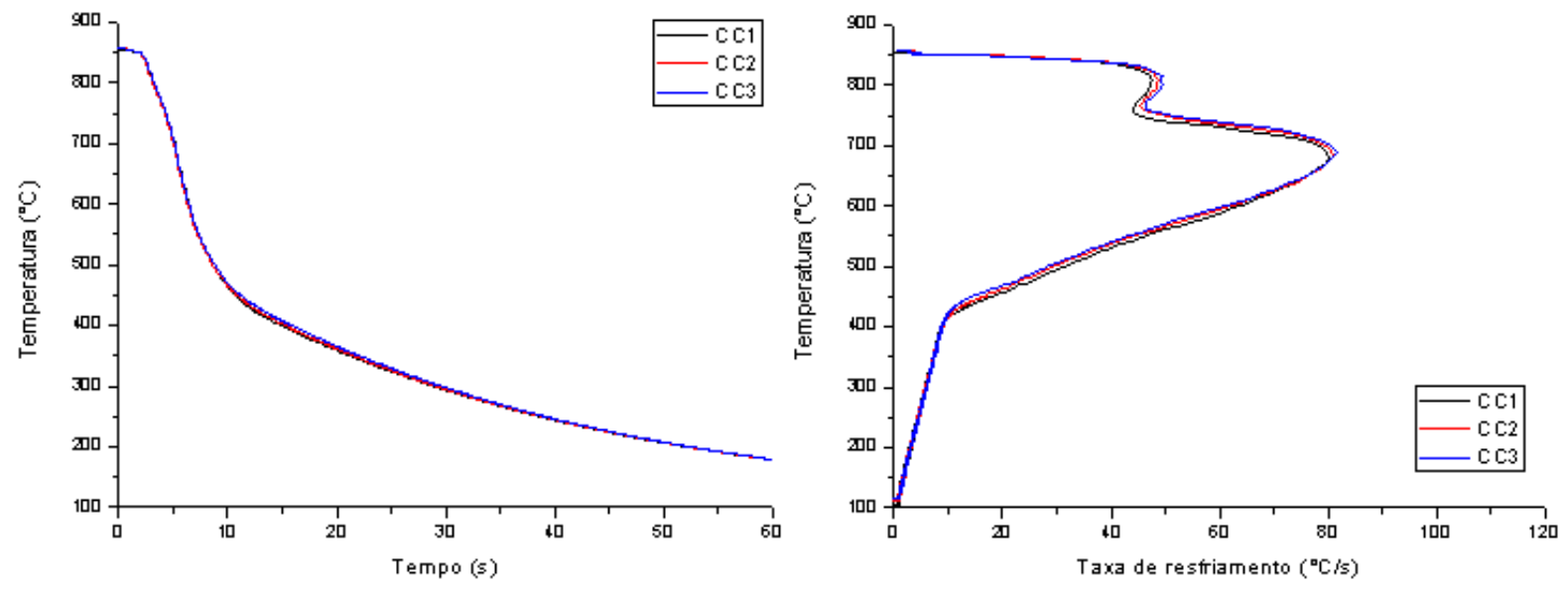

Fonte: Autoria própria.

As curvas de resfriamento do óleo de oliva, Figura 24, assim como os óleos de soja epoxidado e de girassol alto oleico, apresentou curvas estáveis e com pouca alteração de propriedades.

Figura 24. Curvas de Resfriamento do óleo de oliva.
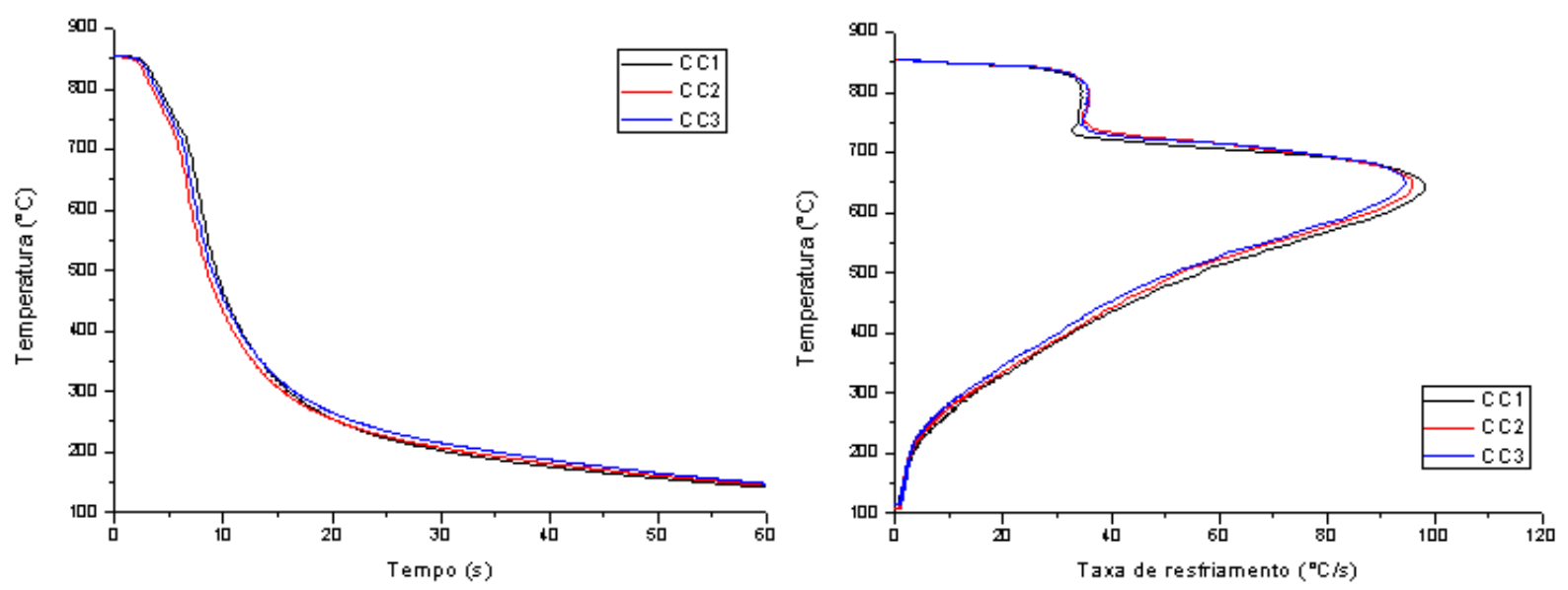

Fonte: Autoria própria. 
No óleo mineral, Figura 25, por se tratar de um fluido comercial específico para esta aplicação, como já esperado, as curvas se mantiveram as estáveis e de excelente desempenho. Apesar de romper a camada de vapor mais lentamente que os outros fluidos vegetais estudados, são observadas taxas máximas de resfriamento muito superiores aos óleos analisados, oferecendo um excelente desempenho para aços de baixa temperabilidade.

Figura 25. Curvas de Resfriamento do óleo mineral.
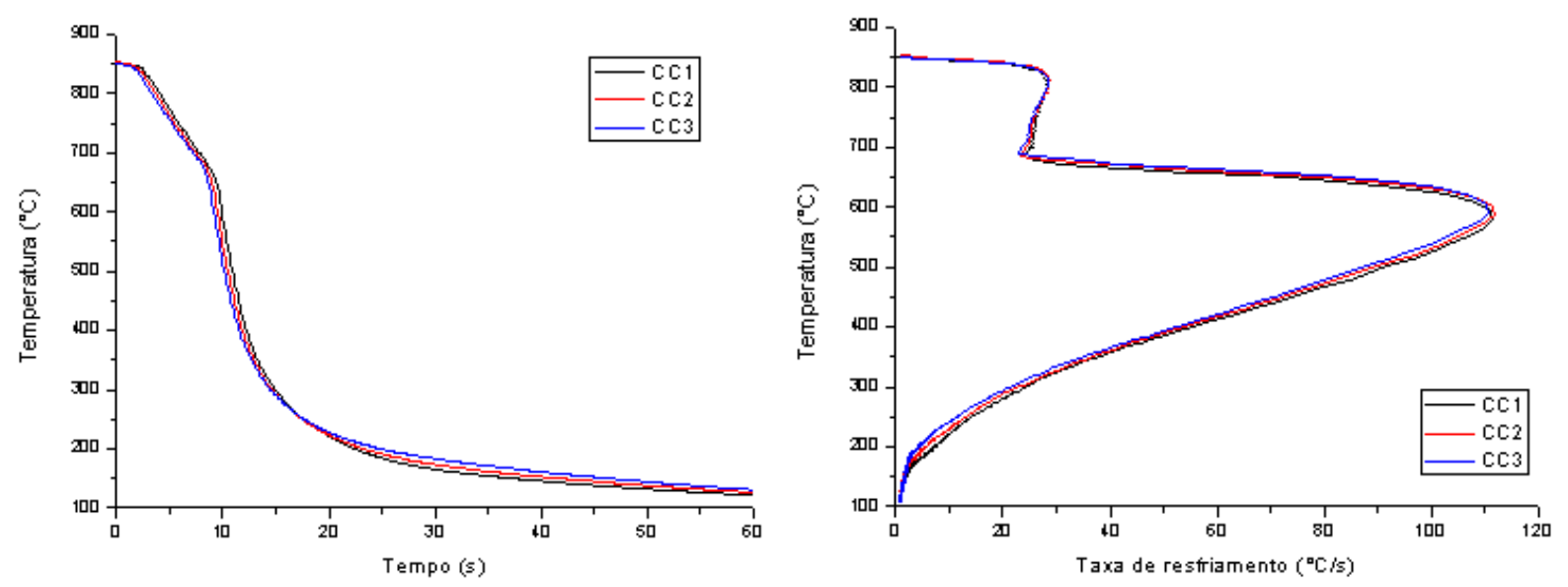

Fonte: Autoria própria.

É importante salientar que o HKM é possui aditivos que melhoram seu desempenho para a têmpera, como por exemplo: facilidade de rompimento de camada de vapor entre óleos minerais (mesmo sem agitação, pois se trata da classe acelerado), alta taxa máxima de resfriamento, baixa viscosidade e excelente molhabilidade do aço.

Após a análise das curvas, foi cogitada a possibilidade de se fazer somente uma curva para cada óleo e descartá-lo em seguida, contudo não seriam dados representativos de uma têmpera industrial, já que o óleo é utilizado mais de uma vez. Adicionalmente, a norma ASTM 6200-01 recomenda um máximo de 50 "têmperas" até o descarte do óleo, contudo esta é uma norma para óleos minerais. Representar esta durabilidade é crucial para averiguar a viabilidade da aplicação como fluido de têmpera. Portanto, foi decidido que os óleos de soja e de girassol seriam excluídos da análise metalúrgica, bem como a análise dos parâmetros de resfriamento. 
Para melhor comparação, a Figura 26 apresenta as curvas dos óleos selecionados para análise e a Tabela 8 indica os principais parâmetros coletados das curvas de resfriamento, com base nelas é possível observar que:

- O maior $\mathrm{CR}_{\max }$ observado nos óleos vegetais foi para o óleo de oliva por volta de $95^{\circ} \mathrm{C} / \mathrm{s}$ contra $111^{\circ} \mathrm{C} / \mathrm{s}$ do óleo mineral HKM;

- A camada de vapor do óleo de oliva foi rompida a $747^{\circ} \mathrm{C}$, sendo a temperatura mais baixa entre os óleos estudados;

- Já o óleo de soja epoxidado teve sua camada rompida a $800^{\circ} \mathrm{C}$, a mais alta entre os óleos, o que é um aspecto bastante favorável visto que a camada de vapor impede a troca eficiente de calor entre fluido e a superfície do metal;

- A 300 e $200^{\circ} \mathrm{C}$ o óleo mineral é o que apresenta maiores taxas de resfriamento, sugerindo que para aços de elevada temperabilidade, este meio é o mais propenso a causar distorções e trincas;

- O óleo de girassol alto oleico apresenta as menores taxas de $300 \mathrm{a}$ $200^{\circ} \mathrm{C}$;

- De forma geral os óleos vegetais analisados apresentaram taxas semelhantes na transição do estágio B-C.

Tabela 8. Resultados extraídos das médias das curvas de resfriamento dos óleos.

\begin{tabular}{ccccc}
\hline Parâmetros & ESBO & HO Sun & Olive & HKM \\
\hline $\mathbf{T}_{\mathrm{A}-\mathrm{B}}\left({ }^{\circ} \mathbf{C}\right)$ & 808 & 762 & 747 & 687 \\
$\mathbf{t}_{\mathrm{A}-\mathrm{B}}(\mathbf{s})$ & 3,38 & 4,00 & 5,25 & 8,00 \\
$\mathbf{C R}_{\mathrm{A}-\mathrm{B}}\left({ }^{\circ} \mathbf{C} / \mathbf{s}\right)$ & 29,36 & 45,02 & 34,53 & 23,52 \\
$\mathbf{C R}_{\max }\left({ }^{\circ} \mathbf{C} / \mathbf{s}\right)$ & 89,07 & 80,85 & 95,54 & 111,27 \\
$\mathbf{T}_{\max }\left({ }^{\circ} \mathbf{C}\right)$ & 693 & 683 & 649 & 587 \\
$\mathbf{t}_{\max }(\mathbf{s})$ & 5,33 & 5,28 & 6,88 & 9,67 \\
$\mathbf{C R}_{700^{\circ} \mathrm{C}}\left({ }^{\circ} \mathbf{C} / \mathbf{s}\right)$ & 88,81 & 79,24 & 72,80 & 24,62 \\
$\mathbf{C R}_{\mathbf{3 0 0}}{ }^{\circ} \mathbf{C}\left({ }^{\circ} \mathbf{C} / \mathbf{s}\right)$ & 10,01 & 5,88 & 13,18 & 22,87 \\
$\mathbf{C R}_{\mathbf{2 0 0}} \mathbf{C}\left({ }^{\circ} \mathbf{C} / \mathbf{s}\right)$ & 2,40 & 3,07 & 2,92 & 5,71 \\
\hline
\end{tabular}

Fonte: Autoria própria. 
Figura 26. Comparação das curvas das taxas de resfriamento.

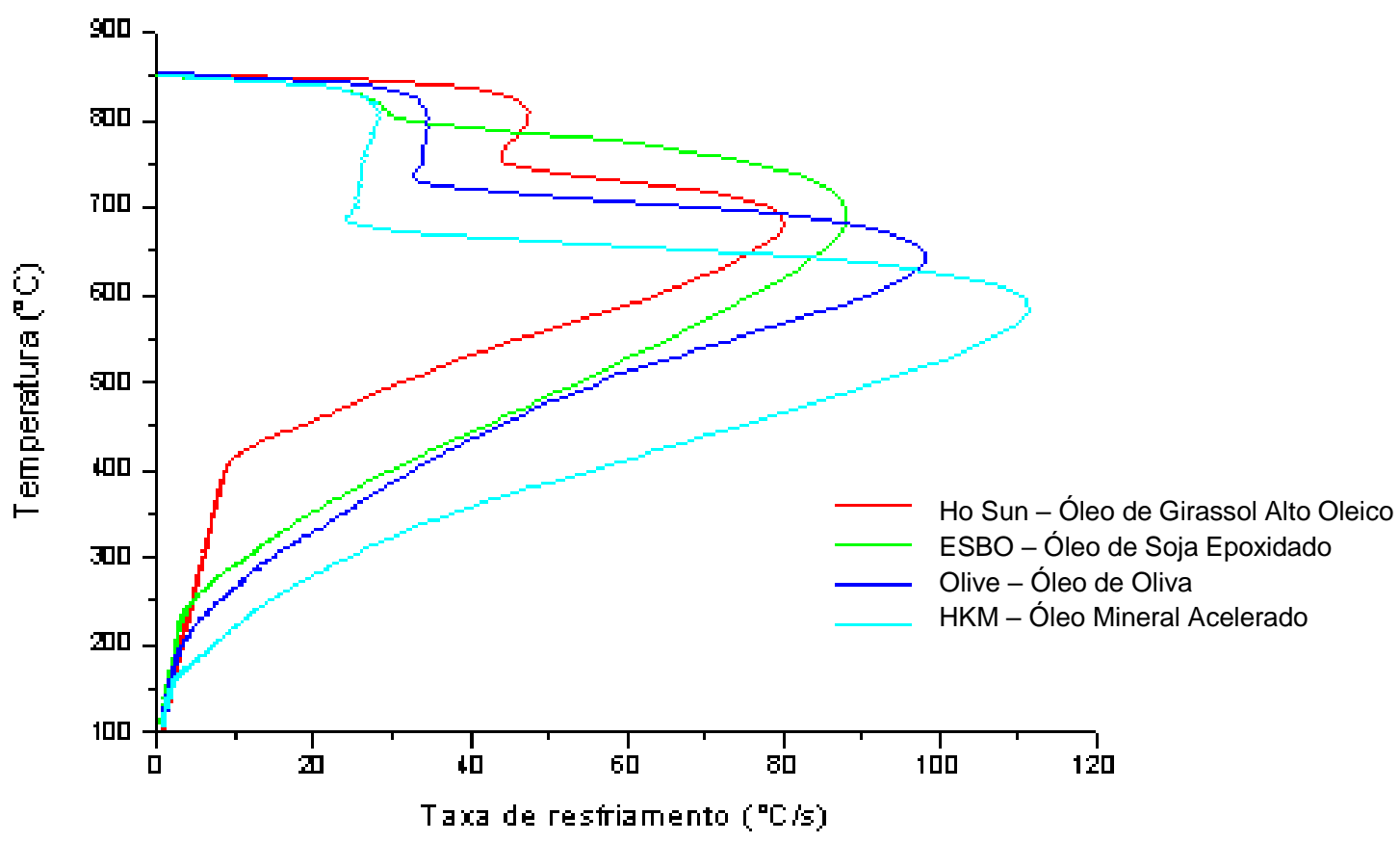

Fonte: Autoria própria.

O coeficiente de transferência de calor ( $\alpha$ ) foi calculado a partir das equações já mencionadas, sendo as condições fixas para o cálculo (i.e. propriedades da sonda Inconel 600) apresentadas na Tabela 9. A Tabela 10 indicam os coeficientes de transferência de calor médio. É esperado que entre os óleos vegetais, o óleo de soja epoxidado e o óleo de oliva apresentem durezas mais altas entre os óleos vegetais. Contudo o HKM é o que exibe maior potencial em extração de calor quando considerado o coeficiente médio de 700 a $200^{\circ} \mathrm{C}$.

Tabela 9. Parâmetros para o cálculo do coeficiente de transferência de calor

\begin{tabular}{|c|c|c|c|}
\hline Parâmetro & Símbolo & Valor & Unidade \\
\hline Raio da sonda & $\mathrm{R}$ & $6,25 \times 10^{-3}$ & $\mathrm{~m}$ \\
\hline $\begin{array}{l}\text { Fator de forma de } \\
\text { Kondratjev }\end{array}$ & $\mathrm{k}$ & $\mathrm{R}^{2} / 5,783=6,75 \times 10^{-6}$ & $m^{2}$ \\
\hline Área superficial & $A / V$ & $2 / R=320$ & $m^{-1}$ \\
\hline Condutividade térmica & $\lambda$ & $\left(200^{\circ} \mathrm{C}\right) 16,0,\left(300^{\circ} \mathrm{C}\right) 17,8 \mathrm{e}\left(700^{\circ} \mathrm{C}\right) 25,9$ & $\mathrm{~W} / \mathrm{mK}$ \\
\hline Difusividade térmica & $a$ & $\begin{array}{l}\left(200^{\circ} \mathrm{C}\right) 4,1 \times 10^{-6},\left(300^{\circ} \mathrm{C}\right) 4,3 \times 10^{-6} \text { e }\left(700^{\circ} \mathrm{C}\right) \\
5,6 \times 10^{-6}\end{array}$ & $\mathrm{~m}^{2} / \mathrm{s}$ \\
\hline
\end{tabular}

Fonte: Autoria própria. 
Tabela 10. Coeficientes médios de transferência de calor.

\begin{tabular}{llll}
\hline Amostra & $\mathbf{7 0 0 - 3 0 0 ^ { \circ } \mathbf { C }}$ & $\begin{array}{c}\mathbf{3 0 0 - 2 0 0} \\
\left(\mathbf{W} / \mathbf{m}^{\mathbf{2}} \mathbf{C}\right)\end{array}$ & $\mathbf{7 0 0 - 2 0 0 ^ { \circ } \mathbf { C }}$ \\
\hline Óleo de Soja Epoxidado & 1417 & 376 & 897 \\
Óleo de Girassol Alto Oleico & 1164 & 294 & 729 \\
Óleo de Oliva & 1276 & 488 & 882 \\
Óleo Mineral Acelerado & 947 & 919 & 933 \\
\hline
\end{tabular}

Fonte: Autoria própria.

Na Tabela 11 é apresentado o índice HP dos óleos vegetais e do mineral estudados. Os resultados apresentam o fluido mineral com HP muito superior aos óleos vegetais. Entre os óleos vegetais o de oliva foi o que exibiu maior HP, enquanto que o alto oleico apresentou valores negativos, indicando que oferece parâmetros insuficientes para aplicação como fluido de têmpera. Contudo, este índice foi criado com base em parâmetros extraídos do comportamento de óleos minerais, conforme já mencionado.

Tabela 11. Poder de endurecimento dos fluidos de têmpera estudados.

\begin{tabular}{lll}
\hline Amostra & Óleos & HP \\
\cline { 2 - 3 } Óleo de Soja Epoxidado & ESBO & 875,7 \\
Óleo de Girassol Alto Oleico & HOSun & - \\
Óleo de Oliva & Olive & 952,3 \\
Óleo Mineral Acelerado & HKM & 1493,6 \\
\hline
\end{tabular}

Fonte: Autoria própria.

De forma geral, o HKM apresentou condições de têmpera mais severas que os óleos vegetais, o que já era esperado para um fluido de sua classificação. O ESBO e o óleo de oliva se mostraram com desempenho superior ao óleo de girassol alto oleico na média do coeficiente de transferência de calor e no índice HP.

Notou-se uma diferença sutil de valores obtidos entre o óleo de oliva e o ESBO, por um lado o índice HP é maior para o primeiro, enquanto que o último possui coeficiente médio de transferência de calor superior.

Os piores resultados, tanto índice HP quanto coeficiente médio de transferência de calor, foram observados no óleo de girassol alto oleico, que apesar da boa 
estabilidade térmica observada nas curvas de resfriamento, mostrou condições de resfriamento menos efetivas.

\subsection{Análise Metalúrgica do aço SAE 1045 antes e após têmpera}

A análise química via espectrometria de emissão óptica revelou que o material é compatível com as especificações de um SAE 1045, conforme indicado na Tabela 12.

Tabela 12. Composição do aço SAE 1045.

\begin{tabular}{|c|c|c|c|c|c|c|c|c|c|}
\hline Identificação & C & Si & Mn & $\mathbf{P}$ & S & $\mathrm{Cr}$ & $\mathrm{Ti}$ & Mo & $\mathbf{N i}$ \\
\hline Amostra & 0,49 & 0,23 & 0,67 & 0,014 & 0,009 & 0,02 & 0,002 & 0,01 & 0,01 \\
\hline $\begin{array}{l}\text { Referência SAE } \\
1045\end{array}$ & $\begin{array}{r}0,42- \\
0,50\end{array}$ & - & $\begin{array}{r}0,60- \\
0,90\end{array}$ & $\begin{array}{c}0,040 \\
\max \end{array}$ & $\begin{array}{c}0,050 \\
\max \end{array}$ & - & - & - & - \\
\hline
\end{tabular}

Fonte: DAVIS, 1996.

Foi realizada, previamente à tempera, uma avaliação do aço normalizado para averiguar se houve descarbonetação após o tratamento témico. Para isto, um perfil de microdureza Vickers foi feito no sentido radial, Figura 27. Constatou-se a presença de leve descabonetação até $0,35 \mathrm{~mm}$ da superfície, porém no caso das macrodurezas superficiais a influência seria pouco significante. A dureza no núcleo também foi medida para este tratamento térmico, o valor obtido foi dentro do esperado para um SAE 1045 normalizado, 96 HRB.

Figura 27. Perfil de microdureza Vickers na superfície da barra normalizada.

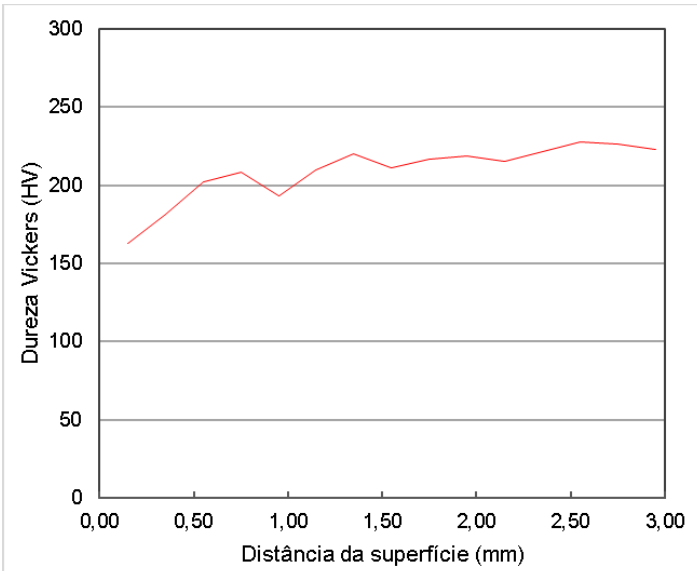

Fonte: Autoria própria. 
As curvas em "U" do aço SAE 1045 temperado nos fluidos vegetais (com exceção dos óleos de soja e girassol, excluídos da análise) e mineral são apresentadas na Figura 28. As durezas de núcleo foram bastante semelhantes, alguns (óleo de soja epoxidado e óleo de girassol alto oleico) com pontos de dureza no centro maiores que nas posições mais externas (exceto pela superfície). Este fenômeno ocorre pela pouca homogeneidade promovida pela têmpera sem agitação. Contudo, não deve ser classificada como dureza inversa, já que os valores de dureza superficial são bastante superiores ao núcleo.

Ainda na Figura 28, constatou-se que as durezas da superfície até metade do raio da amostra foram significativamente maiores na amostra temperada em óleo mineral, indicando maior profundidade de formação da martensita.

Figura 28. Curva em U das amostras de aço SAE 1045 após a têmpera em óleo a $60^{\circ} \mathrm{C}$.

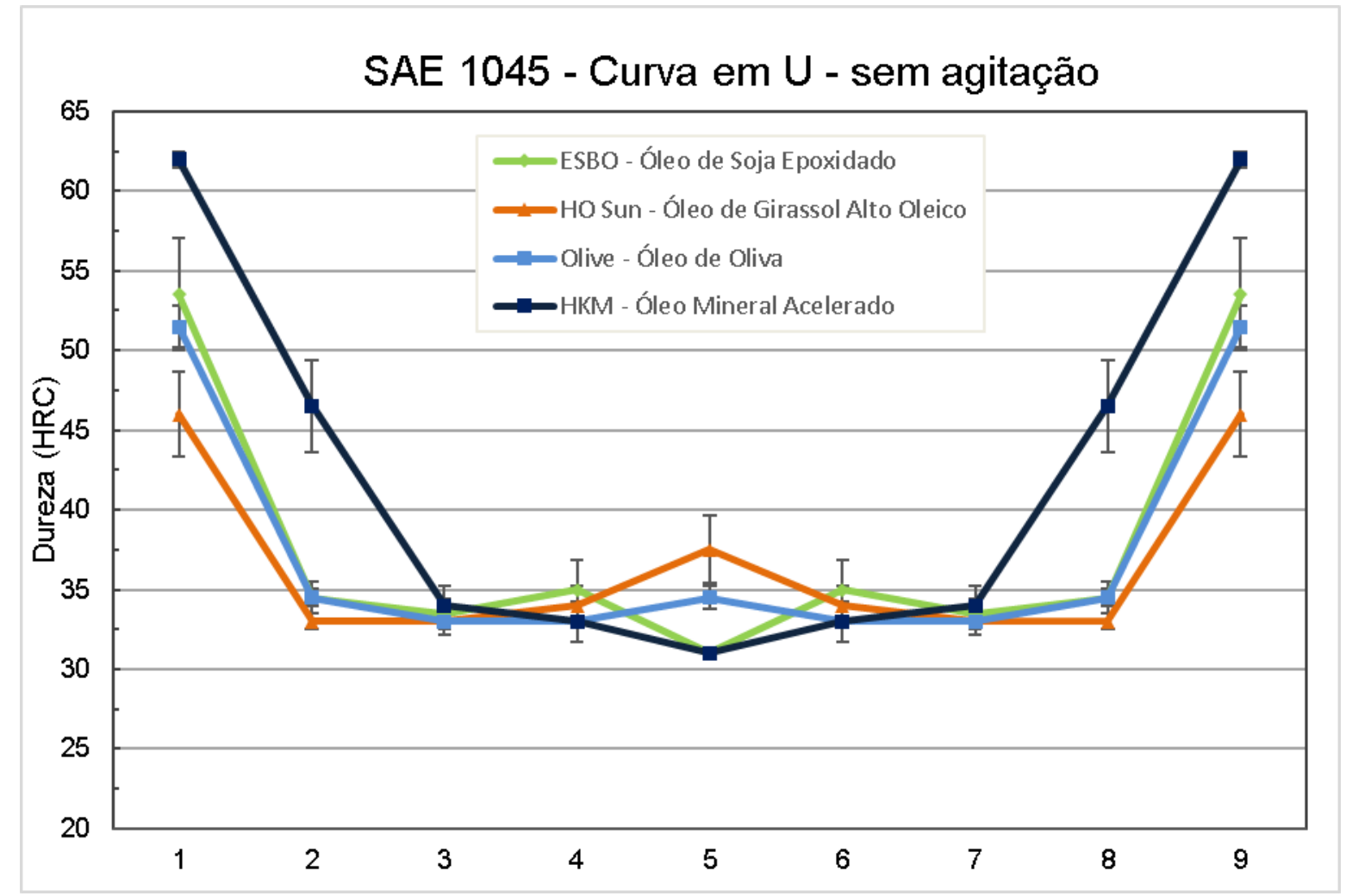

Fonte: Autoria própria.

A Figura 29 apresenta um gráfico em barra com valores de dureza superficial, extraídos da curva em "U". Observa-se um maior valor para a amostra temperada em óleo mineral e também menor desvio padrão (62 HRC). Comparando-se apenas as amostras temperadas em óleo vegetal, observa-se que a de óleo de soja epoxidado 
oferece dureza superior (54 HRC), ainda que muito próxima à de óleo de oliva (52 HRC). Este foi um resultado surpreendente visto que a viscosidade do ESBO é muito superior a dos outros fluidos analisados. A dureza mais baixa foi observada para o óleo de girassol alto oleico (46 HRC), como já previsto pelos parâmetros da curva de resfriamento do mesmo.

Figura 29. Dureza superficial das amostras temperadas.

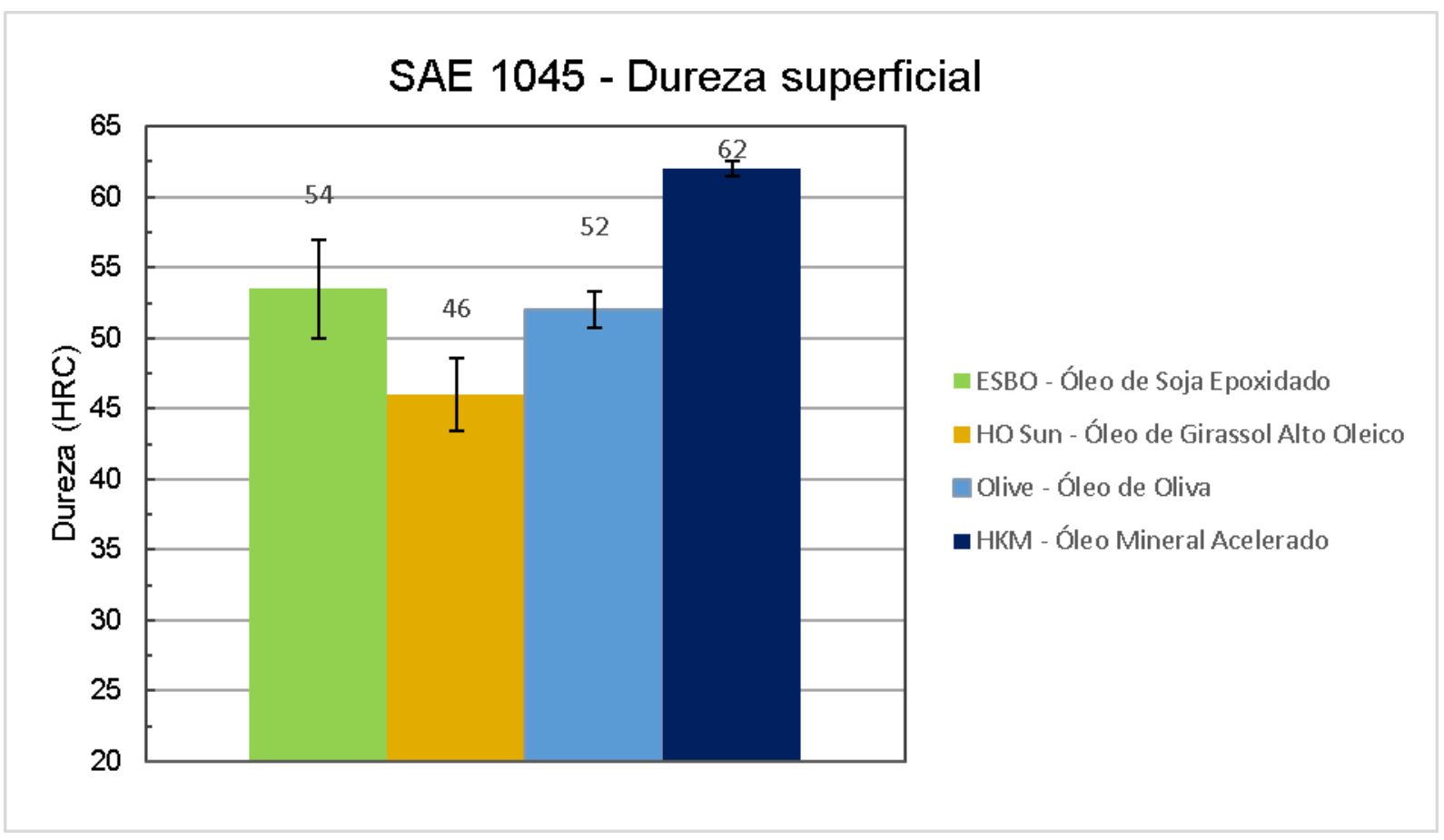

Fonte: Autoria própria.

A Figura 30 apresenta um gráfico que relaciona a dureza com a composição química do aço, desta forma é possível estimar a quantidade de martensita formada. A Tabela 13 indica a formação estimada de martensita pela dureza e pelo cálculo via Image $\mathrm{J}$ na região da superfície do aço após a têmpera. Todos os óleos vegetais chegam a formar pelo menos $50 \%$ de martensita na superfície, porém nenhum dos óleos estudados, incluindo o mineral, formou este teor de martensita no núcleo (durezas abaixo de $45 \mathrm{HRC}$ ), pois trata-se de um aço de baixa temperabilidade. 
Figura 30. Relação aproximada entre a dureza Rockwell C, teor de carbono e formação de martensita.

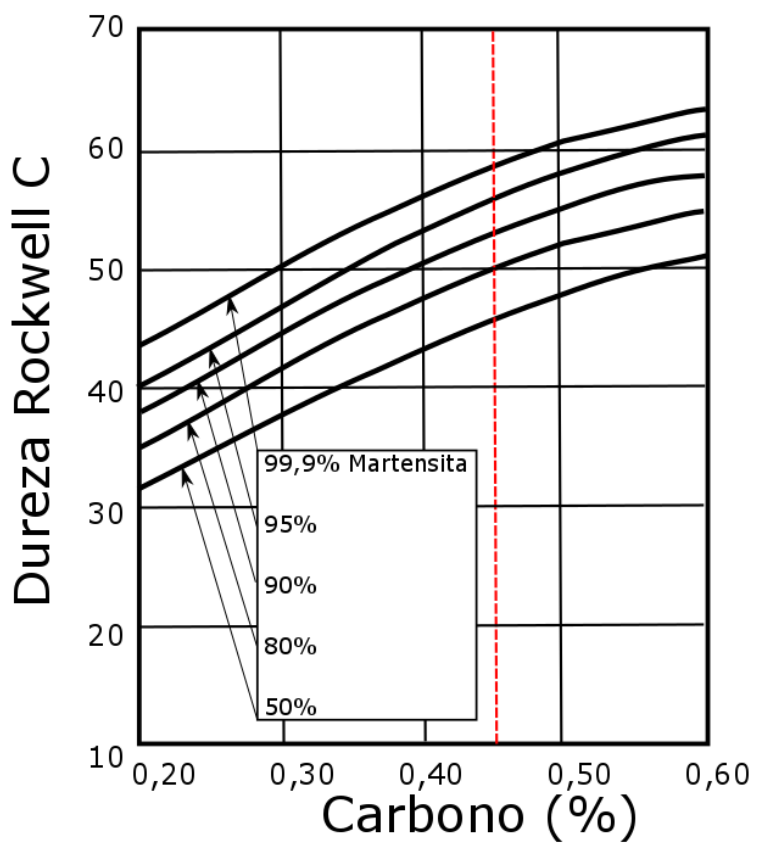

Fonte: Adaptado de COLPAERT, 2008.

Tabela 13. Formação estimada de martensita na superfície dos fluidos estudados.

\begin{tabular}{lccc}
\hline \multicolumn{1}{c}{$\begin{array}{c}\text { Fluido de } \\
\text { resfriamento }\end{array}$} & $\begin{array}{c}\text { Martensita na superfície } \\
\text { calculada por Image J (\%) }\end{array}$ & $\begin{array}{c}\text { Martensita na super- } \\
\text { fície estimada } \\
\text { pela dureza (\%) }\end{array}$ & $\begin{array}{c}\text { Dureza } \\
\text { superficial (HRC) }\end{array}$ \\
\hline $\begin{array}{l}\text { Soja Epoxidado } \\
\text { Girassol }\end{array}$ & 84,3 & $90-95$ & 54 \\
Alto Oleico & 62,2 & 50 & 46 \\
Oliva & 82,9 & $80-90$ & 52 \\
Mineral & 97,6 & 100 & 62 \\
\hline
\end{tabular}

Fonte: Autoria própria.

Apesar do desempenho do óleo mineral ter sido muito superior, o ESBO e óleo de oliva apresentaram bom desempenho sem agitação e sem a presença de aditivos que beneficiariam a têmpera. Adicionalmente, o óleo de soja epoxidado prova que os óleos vegetais quando modificados podem atingir propriedades desejáveis para a têmpera: boa estabilidade térmica, rápido rompimento da camada de vapor e coeficientes de transferência de calor satisfatórios.

Com o propósito de averiguar qual método melhor representa o comportamento dos fluidos de resfriamento estudados, foi feita uma correlação entre o coeficiente 
médio de transferência de calor, o de Poder de Endurecimento e as durezas superficiais medidas após a têmpera do SAE 1045, Figura 31. Excluiu-se o ponto que representa o índice HP e dureza do óleo de girassol alto oleico, pois como já mencionado, este é um índice construído a partir de temperas realizadas com óleos minerais, portanto, a aplicação para óleos vegetais é imprecisa.

$\mathrm{Na}$ Figura 31 a linha de tendência exponencial parece ser mais sensível às variações de dureza para o índice HP que para o coeficiente médio de transferência de calor, e também apresenta $\mathrm{R}^{2}$ superior. Contudo, as melhores correlações de dureza superficial foram observadas para o coeficiente médio de transferência de calor. Portanto, o índice HP tem aplicação bastante limitada para representar o comportamento de fluidos de origem vegetal.

Figura 31. Correlação entre os métodos para quantificar severidade de têmpera.

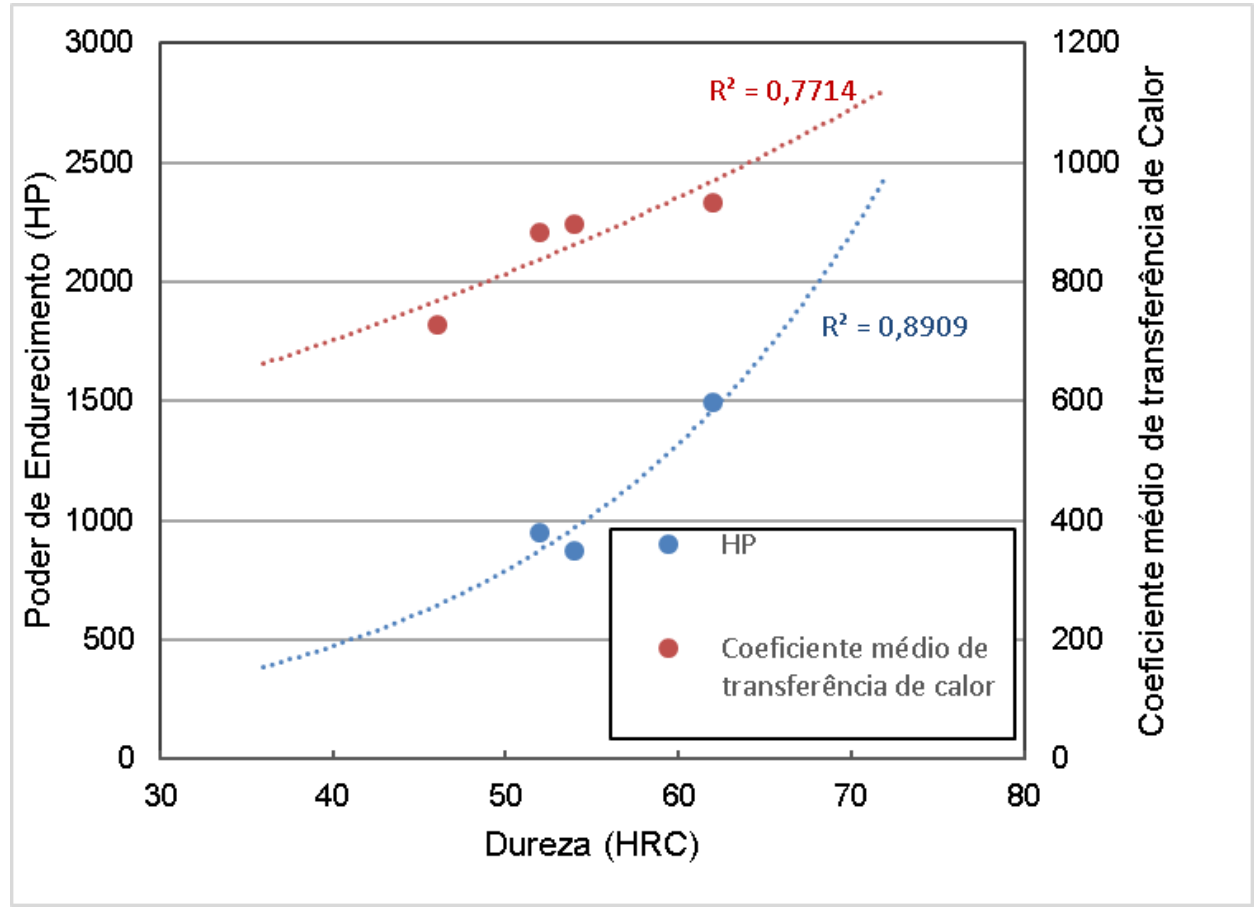

Fonte: Autoria própria.

A Figura 32 mostra as metalografias das regiões superfície e centro da amostra normalizada. A amostra após a normalização apresentou leve descarbonetação, assim como constatado pelo perfil de microdureza Vickers da Figura 27. A microestrutura observada é de perlita e ferrita, como esperado para este aço carbono após realizado tratamento de normalização. 
Figura 32. Metalografia do aço SAE 1045 normalizado a $850^{\circ} \mathrm{C}$ por $2 \mathrm{~h}$ e resfriado ao ar superfície e núcleo (ataque em Nital 2\%). Aumento de 100x.
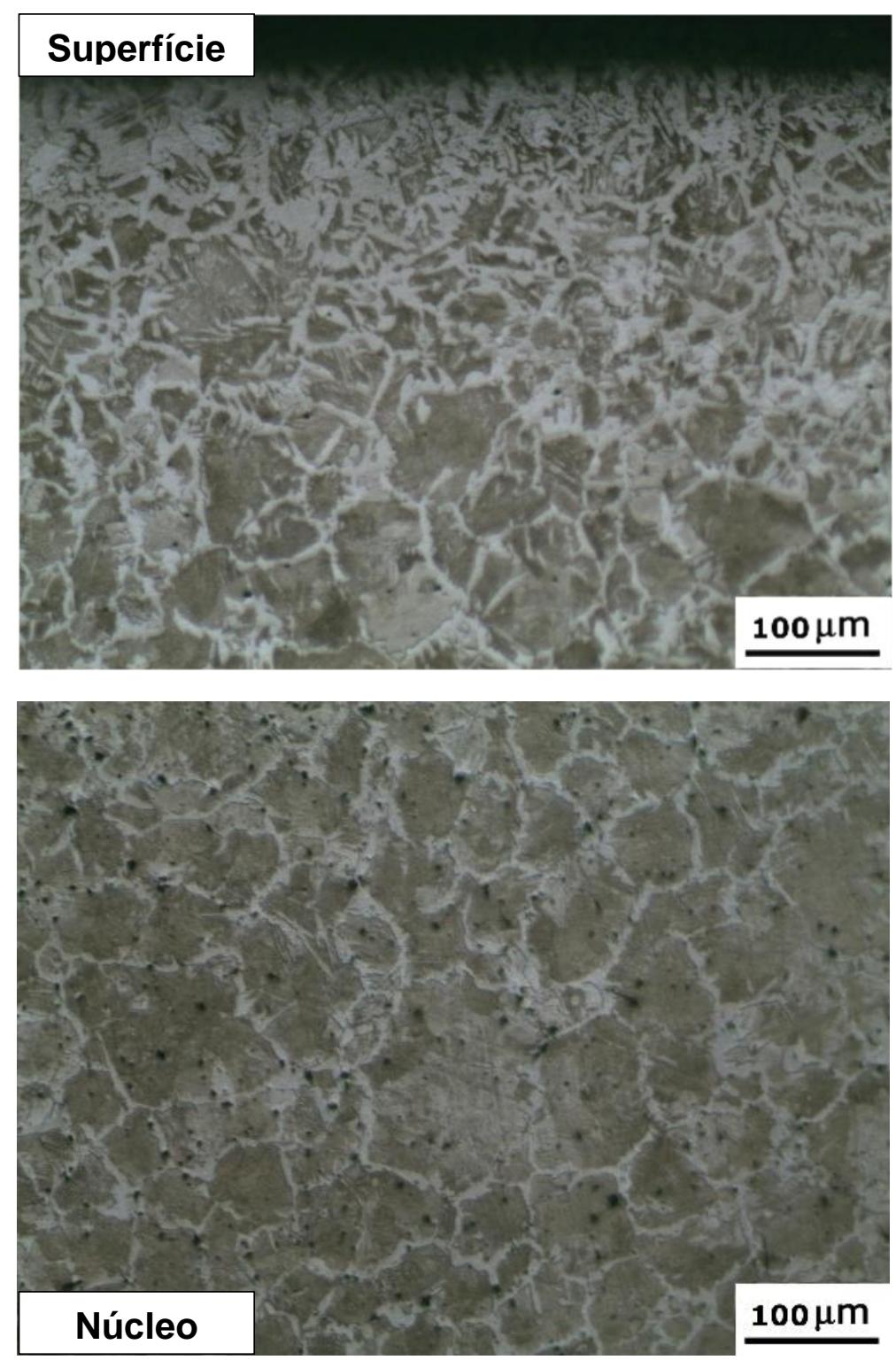

Fonte: Autoria própria.

As Figuras 33 a 36 apresentam as metalografias das amostras temperadas nos fluidos estudados. Nota-se evidente formação de martensita na superfície de todas amostras temperadas, assim como apresentado nas curvas em "U" da Figura 28. Os óleos vegetais formaram, visivelmente menores teores de martensita na superfície que o óleo mineral. No centro as amostras indicaram microestruturas similares, assim como constatado nas análises de dureza. 
Entre os óleos vegetais, as camadas de martensita que atingiram maior profundidade foram nos óleos de soja epoxidado e de oliva, ainda que muito inferior à exibida pela amostra temperada em óleo mineral.

Figura 33. Metalografia do aço SAE 1045 normalizado a $850^{\circ} \mathrm{C}$ por $2 \mathrm{~h}$ e temperado em óleo de soja epoxidado a $60^{\circ} \mathrm{C}$ superfície e núcleo. Aumentos de 20 e 100x.
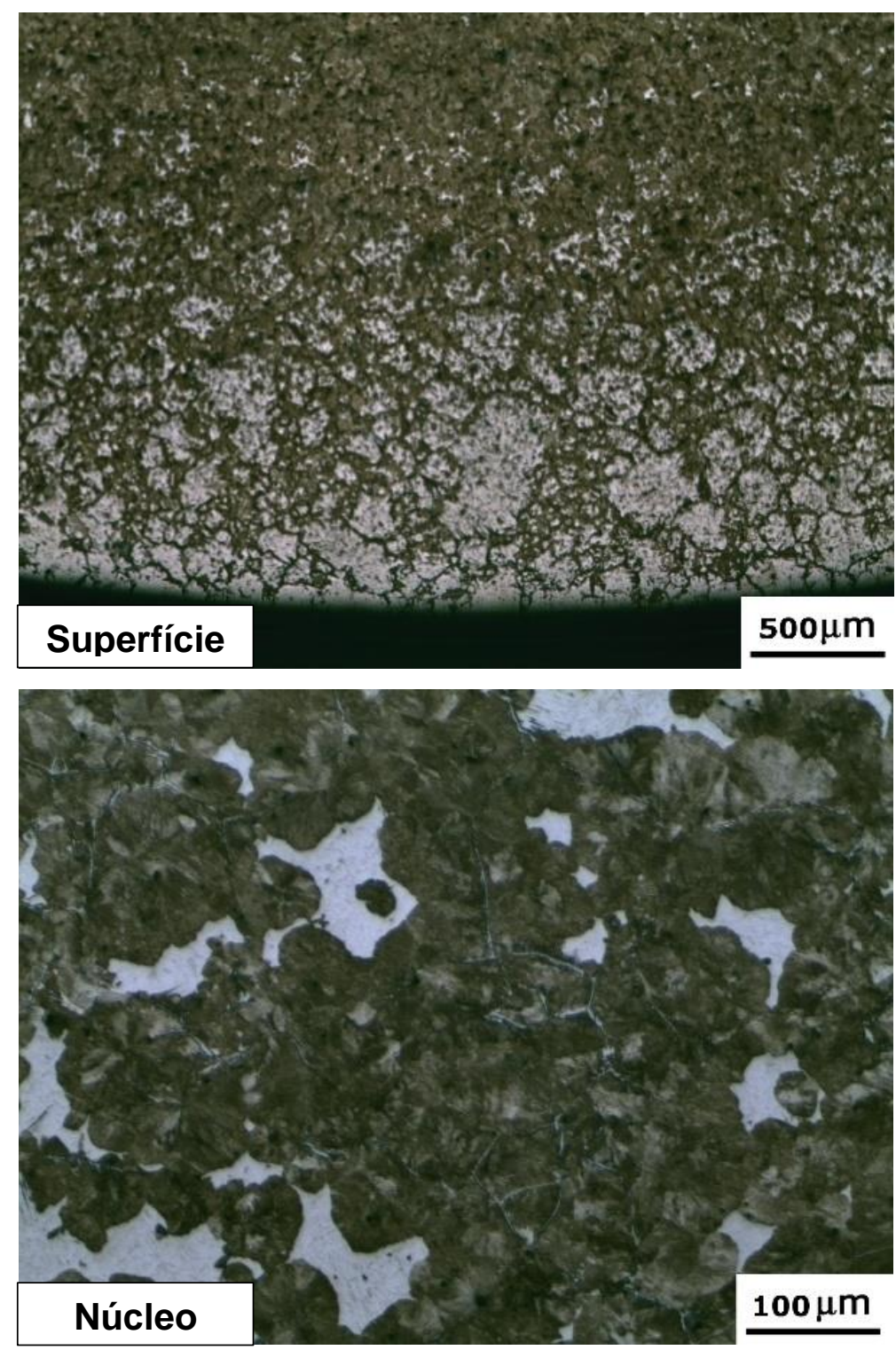

Fonte: Autoria própria. 
Figura 34. Metalografia do aço SAE 1045 normalizado a $850^{\circ} \mathrm{C}$ por $2 \mathrm{~h}$ e temperado em óleo de girassol alto oleico a $60^{\circ} \mathrm{C}$ superfície e núcleo. Aumentos de 20 e 100x.
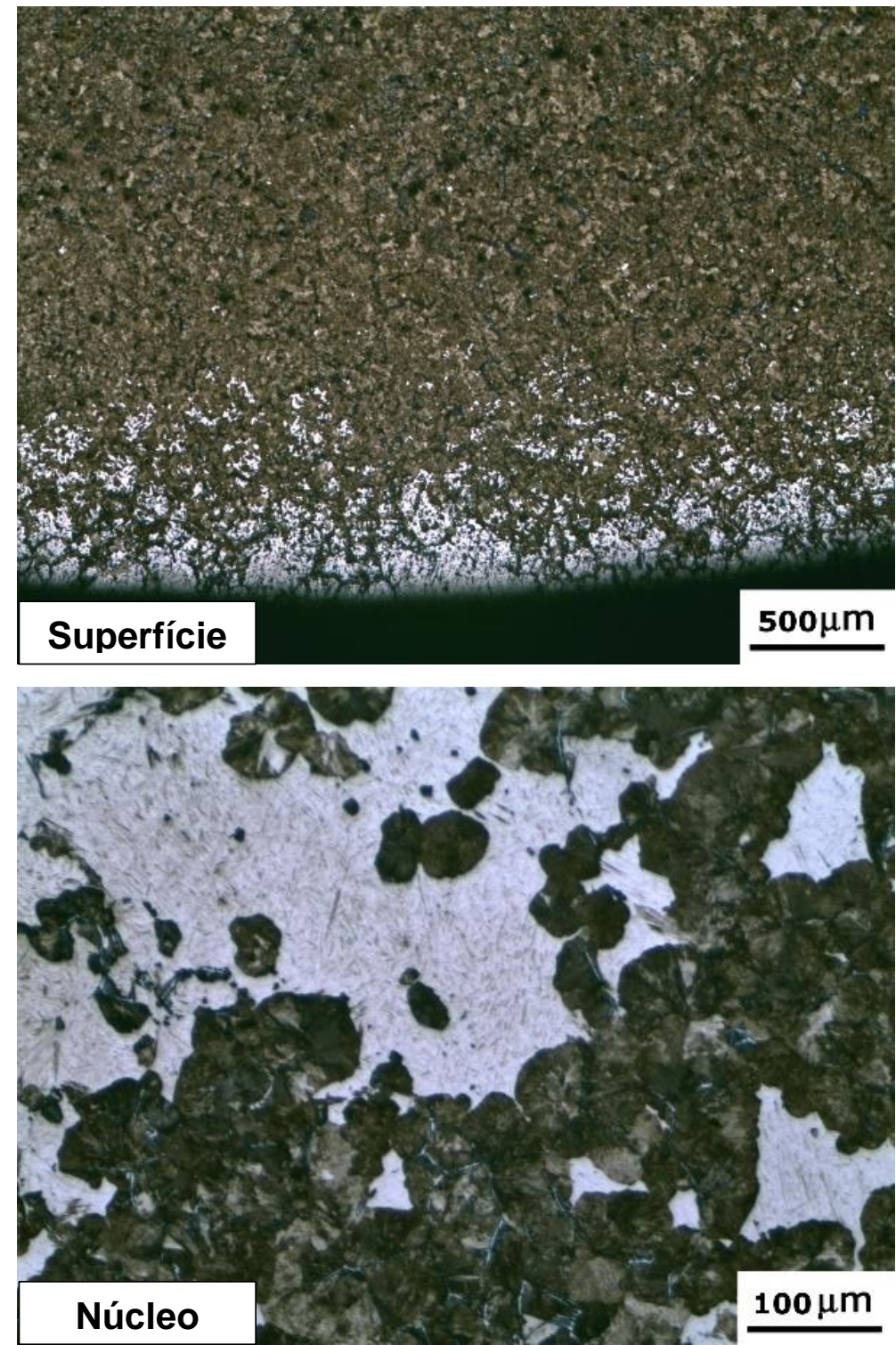

Fonte: Autoria própria. 
Figura 35. Metalografia do aço SAE 1045 normalizado a $850^{\circ} \mathrm{C}$ por $2 \mathrm{~h}$ e temperado em óleo de oliva a $60^{\circ} \mathrm{C}$ superfície e núcleo. Aumentos de 20 e $100 x$.
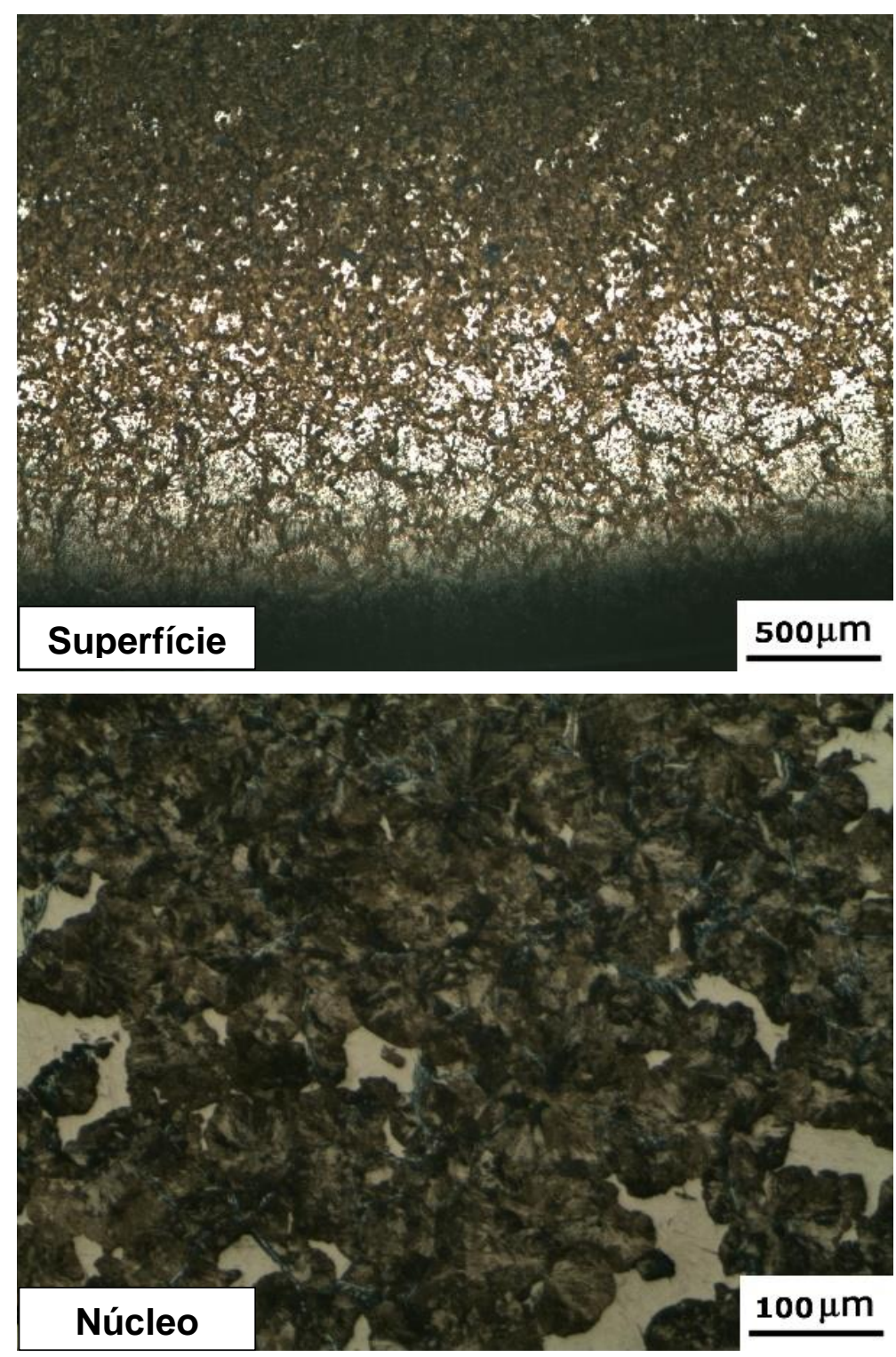

Fonte: Autoria própria. 
Figura 36. Metalografia do aço SAE 1045 normalizado a $850^{\circ} \mathrm{C}$ por $2 \mathrm{~h}$ e temperado em óleo mineral HKM a $60^{\circ} \mathrm{C}$ superfície e núcleo. Aumentos de 20 e 100x.
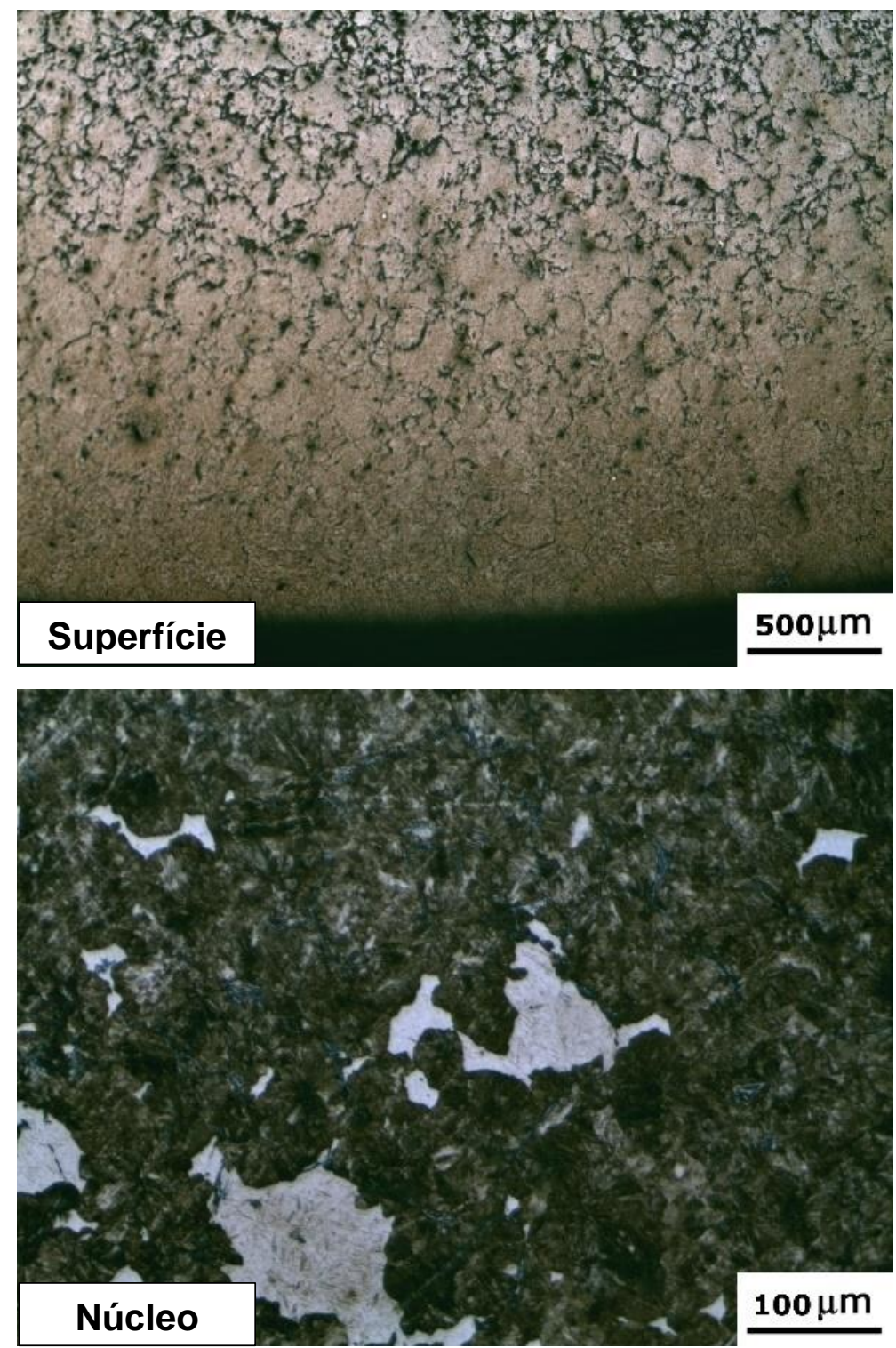

Fonte: Autoria própria.

No núcleo de todas amostras temperadas constatou-se a presença de uma fase clara que com maior ampliação aparentava ser martensita. Para confirmação, foram feitas algumas microdurezas Vickers na região que apresentou dureza em torno de $713 \mathrm{HV}$, portanto, certificando de que realmente se tratava de martensita (Figura 37). 
Figura 37. Metalografia da região branca no centro com dureza Vickers. Aumento de 200x.

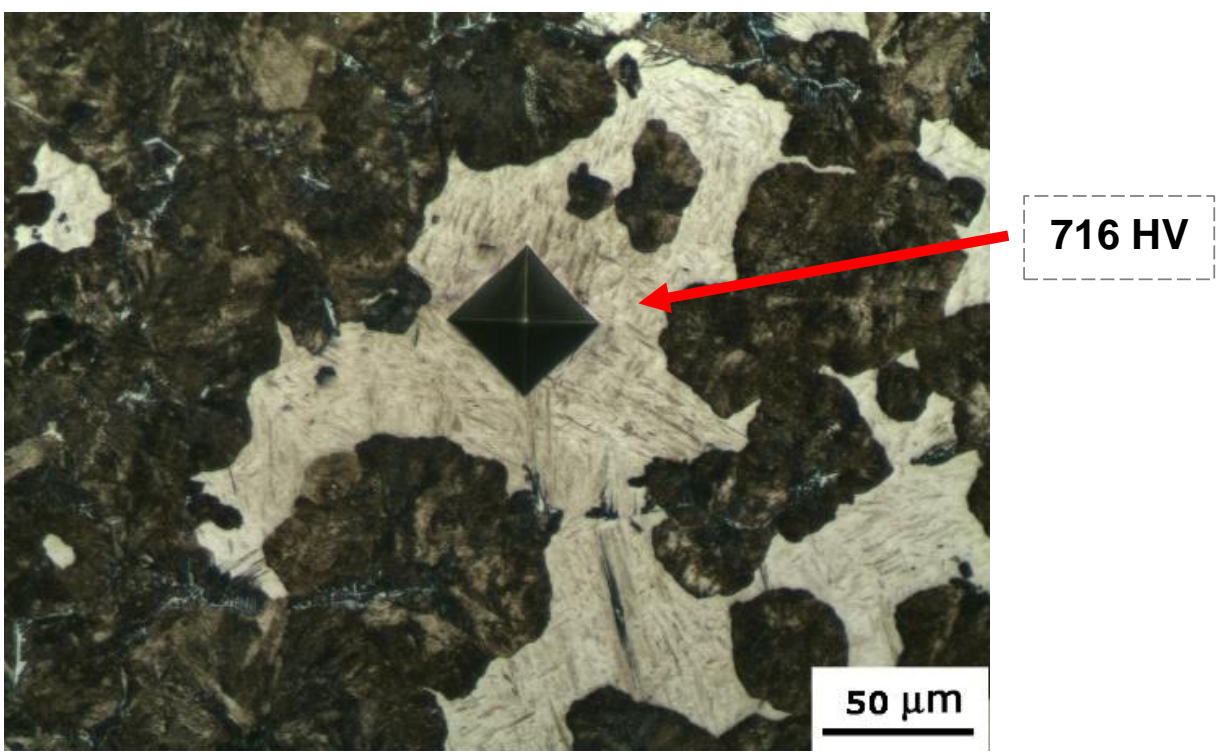

Fonte: Autoria própria.

A formação de martensita no centro é em decorrência de que a amostra era de comprimento (1" polegada) suficientemente pequeno para que o efeito de borda se tornasse significante. Grossman indica peças de pelo menos quatro vezes o diâmetro para o levantamento das curvas em $U$, portanto as proporções utilizadas neste trabalho afetaram a forma como o calor foi removido da peça durante a têmpera, combinando extrações nos sentidos radiais e axiais Figura 38.

Figura 38. Influência da razão de aspecto da amostra no fluxo de calor.

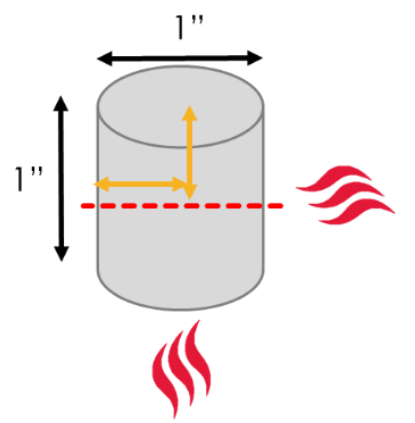

Fonte: Autoria própria. 


\section{CONCLUSÕES}

Os ensaios de Ressonância Magnética Nuclear de Hidrogênio indicaram a presença de maiores teores de insaturações nos óleos de soja e girassol. Esta característica se manifestou compatível ao comportamento observado nas curvas de resfriamento dos mesmos, visto que maiores teores de poli-insaturados provocam aumento da instabilidade térmica. Este comportamento mostra que a aplicação de óleos vegetais como fluido de têmpera carece de modificações químicas para alcançar propriedades satisfatórias, essencialmente a estabilidade.

O desempenho caracterizado tanto pelo Poder de Endurecimento (HP) quanto pelo coeficiente médio de transferência de calor estimou que entre os óleos vegetais, com exceção dos eliminados da análise, o óleo de oliva e o de soja epoxidado ofereceriam durezas superiores, o que de fato foi observado nas têmperas com o aço SAE 1045. Foi observada melhor correlação com as durezas para o coeficiente médio de transferência de calor que para o índice HP, visto que o último foi formulado com base na avaliação de óleos minerais.

Estes índices também demonstram que o óleo mineral (HKM) oferece capacidade de extração de calor muito superior. Contudo, se trata de um óleo comercial aditivado para tal aplicação e com excelentes propriedades de resfriamento para tal.

O ensaio de viscosidade mostrou que existe um aumento significativo da viscosidade do óleo modificado quimicamente, contudo seu desempenho mostrou-se melhor que o esperado. É importante salientar que apesar das modificações químicas deste óleo, sua biodegradabilidade é pouco afetada, provando ser uma excelente alternativa aos fluidos de resfriamento tradicionais.

A medida de viscosidade também revelou que o óleo mineral possui viscosidade significativamente menor que os outros óleos na temperatura de $60^{\circ} \mathrm{C}$, oferecendo taxas de resfriamento superiores, contudo é provavelmente o óleo com maior teor de voláteis, o que faz com que sua camada de vapor se rompa com mais tempo que os óleos vegetais analisados.

É possível concluir que os óleos vegetais que exibiram curvas de resfriamento mais estáveis (óleo de soja epoxidado, óleo de girassol alto oleico e óleo de oliva) tem potencial aplicação como fluidos de têmpera, indicando que com modificações 
químicas e/ou aditivação podem convergir suas propriedades para uma têmpera de melhor desempenho em aços de baixa temperabilidade. Outra possibilidade é a utilização destes óleos vegetais com menor poder de extração de calor como fluidos de têmpera de aços de elevada temperabilidade e/ou que apresentam distorções e trincas, visto que suas taxas de resfriamento de 300 a $200^{\circ} \mathrm{C}$ são mais brandas que no óleo mineral em questão. 


\section{SUGESTÕES PARA TRABALHOS FUTUROS}

Como forma de complementar este trabalho, é sugerida a avaliação da degradação dos óleos vegetais após a têmpera, como forma de constatar quais são as modificações apresentadas, em termos de viscosidade e distribuição de ácidos graxos. Deste modo, sugerindo tratamentos químicos para retardar estas modificações sem que haja perda significativa das propriedades de resfriamento.

Avaliação destes fluidos de resfriamento na têmpera de aços de maior temperabilidade, como por exemplo o SAE 4140. Desta forma, averiguando o potencial de aplicação destes fluídos de resfriamento menos severo como forma de minimizar distorções causadas pela têmpera.

Elaboração de um índice HP que melhor represente o comportamento dos óleos vegetais como fluidos para têmpera, utilizando dados provenientes das curvas de resfriamento e análises de dureza de amostras de aço temperadas nestes fluidos. 


\section{REFEFÊNCIAS}

ADHVARYU, A.; ERHAN, S. Z. Epoxidized soybean oil as a potential source of hightemperature lubricants. Industrial Crops \& Products, v. 15, p. 247-254, 2002.

ADHVARYU, A.; ERHAN, S. Z.; LIU, Z. S.; PEREZ, J. M. Oxidation kinetic studies of oils derived from unmodi ${ }^{\circledR}$ ed and genetically modi ${ }^{\circledR}$ ed vegetables using pressurized differential scanning calorimetry and nuclear magnetic resonance spectroscopy. , v. 364, p. 87-97, 2000.

ADHVARYU, A.; LIU, Z.; ERHAN, S. Z. Synthesis of novel alkoxylated triacylglycerols and their lubricant base oil properties. Industrial Crops \& Products, v. 21, p. 113119, 2005.

ADOLFSSON, H. Modern Oxidation Methods. 2nd ed. WILEY-VCH, 2004.

AGÊNCIA FAPESP. Proálcool: uma das maiores realizações do Brasil baseadas em ciência e tecnologia. Disponível em: <http://agencia.fapesp.br/print/proalcool-umadas-maiores-realizacoes-do-brasil-baseadas-em-ciencia-e-tecnologia/24432/>.

Acesso em: 20/12/2018.

ASTM. Standard Test Method for Determination of Cooling Characteristics of Quench Oils by Cooling Curve Analysis - ASTM D6200-01. , 2001.

ASTM. Standard Test Method for Kinematic Viscosity of Transparent and Opaque Liquids (and Calculation of Dynamic Viscosity) - ASTM D445-18. , 2018.

ASTM. Standard Test Methods for Rockwell Hardness of Metallic Materials - ASTM E18-19. , 2019.

BOCKISCH, M. Fats and Oils Handbook. Hamburg, Germany: AOCS Press, 1998.

BOLDRINI, D. E. Monolithic stirrer reactor for vegetable oil hydrogenation: A technical and economic assessment. Chemical Engineering and Processing: Process Intensification, v. 132, p. 229-240, 2018.

BRITO, P.; RAMOS, P. A.; RESENDE, L. P.; FARIA, D. A. DE; RIBAS, O. K. Experimental investigation of cooling behaviour and residual stresses for quenching with vegetable oils at different bath temperatures. Journal of Cleaner Production, v. 216, p. 230-238, 2019. Journal of Cleaner Production.

BROCK, J.; NOGUEIRA, M. R.; ZAKRZEVSKI, C.; et al. Determinação experimental da viscosidade e condutividade térmica de óleos vegetais. Ciência e Tecnologia de Alimentos, v. 28, n. 002343, p. 564-570, 2008.

BROOKS, C. R. Heat Treatment of Plain Carbon and Low-Alloy Steels. 1st ed. Ohio: ASM International, 1996.

CAMPANELLA, A.; FONTANINI, C.; BALTANÁS, M. A. High yield epoxidation of fatty acid methyl esters with performic acid generated in situ. Chemical Engineering 
Journal, v. 144, p. 466-475, 2008.

CHIAVERINI, V. Aços e Ferros Fundidos: características gerais, tratamentos térmicos, principais tipos. $7^{a}$ ed. São Paulo: Associação Brasileira de Metalurgia e Metais, 2008.

CHUN-HUAI, C.; JING-EN, Z. Analysis of the Segerberg Hardening Power Equation. Journal of ASTM International, v. 6, n. 1, p. 1021-1031, 2010.

COLPAERT, H. Metalografia dos Produtos Siderúrgicos Comuns. $4^{a}$ ed. São Paulo: Edgard Blucher, 2008.

CREVEL, R. W. R.; KERKHOFF, M. A. T.; KONING, M. M. G. Allergenicity of Refined Vegetable Oils. Food and Chemical Toxicology, v. 38, p. 385-393, 2000.

DAIS, P.; HATZAKIS, E.; FRAGAKI, G.; et al. Comparison of Analytical Methodologies Based on $1 \mathrm{H}$ and $31 \mathrm{P}$ NMR Spectroscopy with Conventional Methods of Analysis for the Determination of Some Olive Oil Constituents. Journal of Agricultural and Food Chemistry, v. 55, p. 577-584, 2007.

DAVIS, J. R. D. Carbon and Alloy Steels. Ohio: ASM International, 1996.

DEIVAJOTHIA, P.; MANIENIYANB, V.; SIVAPRAKASAM, S. Experimental investigation on $\mathrm{DI}$ diesel engine with fatty acid oil from by-product of vegetable oil refinery. Ain Shams Engineering Journal, v. 10, p. 77-82, 2019.

FLINT, V.; DAVIDSON, G. M.; BORING, R. L.; POWERS, C. L. Heat Treater's Guide. 2nd ed. ASM International, 1995.

FONSECA, H.; GUTIERREZ, L. E. Composição em ácidos graxos de óleos vegetais e gorduras animais. Anais da ESALQ, v. XXXI, n. 1974, p. 485-490, 1974.

GAMAGE, P. K.; BRIEN, M. O.; KARUNANAYAKE, L. Epoxidation of some vegetable oils and their hydrolysed products with peroxyformic acid - optimised to industrial scale. Journal of National Science Foundation of Sri Lanka, v. 37, n. 4, p. 229-240, 2009.

GOVERNO DO BRASIL. Matriz energética. Disponível em: <http://www.brasil.gov.br/noticias/meio-ambiente/2010/11/matriz-energetica>. Acesso em: 19/12/2018.

GUILLÉN, M. D.; RUIZ, A. Rapid simultaneous determination by proton NMR of unsaturation and composition of acyl groups in vegetable oils. European Journal of Lipid Science and Technology, v. 105, p. 688-696, 2003.

GUNSTONE, F. D. Vegetable oils. In: Bailey's Industrial Oil and Fat Products. 6th ed. John Wiley \& Sons, Inc, 2005.

HOPKINS, C. Y.; BERNSTEIN, H. J. Applications of proton magnetic resonance spectra in fatty acid chemistry. Canadian Journal of Chemistry, v. 37, n. 5093, p. 775-782, 1959.

HUTH, P. J.; FULGONI, V. L.; LARSON, B. T. A Systematic Review of High-Oleic 
Vegetable Oil Substitutions for Other Fats and Oils on Cardiovascular Disease Risk Factors : Implications for Novel High-Oleic Soybean Oils. Advances in Nutrition, v. 6, n. 2, p. 674-693, 2015.

JI, D.; FANG, Z.; HE, W.; et al. Polyurethane rigid foams formed from different soybased polyols by the ring opening of epoxidised soybean oil with methanol, phenol, and cyclohexanol. Industrial Crops \& Products, v. 74, p. 76-82, 2019.

KHAN, A. Bleaching of Vegetable Oil using Organic Acid Activated Fuller's Earth (Bentonite Clay). Global Journal of Researches in Engineering, v. 15, n. 2, p. 0-6, 2015.

KHUNDAMRI, N.; AOUF, C.; FULCRAND, H.; DUBREUCQ, E.; TANRATTANAKUL, $V$. Bio-based flexible epoxy foam synthesized from epoxidized soybean oil and epoxidized mangosteen tannin. Industrial Crops \& Products, v. 128, p. 556-565, 2019.

KOBASKO, N. I.; CANALE, L. C. F.; TOTTEN, G. Vegetable Oil Quenchants: Calculation and Comparison of The Cooling Properties of a Series of Vegetable Oils. Journal of Mechanichal Engineering, v. 56, n. August 2015, p. 131-142, 2010.

KODALI, D. R. High performance ester lubricants from natural oils. Industrial Lubrication and Tribology, v. 54, p. 165-170, 2002.

KRAUSS, G. Steels: heat treatment and processing principles. Ohio: ASM International, 1989.

LEONARDI, J. G.; AZEVEDO, B. M.; ROMANO, L. H. AVALIAÇÃO DAS INSATURAÇÕES DE AZEITES EXTRAS VIRGENS PELO ÍNDICE DE IODO (MÉTODO DE WIJS). Revista Saúde em Foco, v. 10, p. 17-30, 2018.

MAMBRINI, G. P.; RIBEIRO, C.; COLGNAGO, L. A. Nuclear magnetic resonance spectroscopic analysis of ethyl ester yield in the transesteri fi cation of vegetable oil : an accurate method for a truly quantitative analysis. Magnetic Resonance in Chemistry, v. 50, p. 1-4, 2012.

MANNINA, L.; SEGRE, A. High Resolution Nuclear Magnetic Resonance: From Chemical Structure to Food Authenticity. Grasas y Aceites, v. 53, p. 22-33, 2002.

MCNUTT, J.; HE, Q. Development of biolubricants from vegetable oils via chemical modification. Journal of Industrial and Engineering Chemistry, v. 36, p. 1-12, 2016.

NASCIUTTI, P. R.; COSTA, A. P. A.; JÚNIOR, M. B. DOS S.; MELO, N. G. DE; CARVALHO, R. DE O. A. Ácidos Graxos e o sistema cardiovascular. Enciclopedia Biosfera, v. 11, p. 11-29, 2015.

OTERO, R. L. S. Calculation of Kobasko's Simplified Heat Transfer Coefficients from Cooling Curve Data Obtained with Small Probes. Journal of ASTM International, v. 9, n. 4, p. 1-8, 2012.

OTERO, R. L. S. Potencialidade do uso de formulações de óleo de soja 
epoxidado e éster metílico de ácido graxo como fluidos de resfriamento no tratamento térmico de têmpera de aços, 2014. Tese (doutorado em Ciência e Engenharia de Materiais). Universidade de São Paulo, São Carlos.

OTERO, R. L. S.; CANALE, L. C. F.; TOTTEN, G. E.; MEEKISHO, L. Vegetable Oils as Metal Quenchants: A Comprehensive Review. Materials Performance and Characterization, v. 6, n. 1, p. 174-250, 2017.

QUINCHIA, L. A.; DELGADO, M. A.; VALENCIA, C.; FRANCO, J. M.; GALLEGOS, C. Viscosity Modification of High-Oleic Sunflower Oil with Polymeric Additives for the Design of New Biolubricant Formulations. Environmental science \& techonology, v. 43, n. 6, p. 2060-2065, 2009.

RA, M.; LV, Y. Z.; ZHOU, Y.; et al. Use of vegetable oils as transformer oils - a review. Renewable and Sustainable Energ Reviews, v. 52, p. 308-324, 2015.

RAMESH, G.; PRABHU, K. N. Wetting kinetics, kinematics and heat transfer characteristics of pongamia pinnata vegetable oil for industrial heat treatment. Applied Thermal Engineering, v. 65, n. 1-2, p. 433-446, 2014. Elsevier Ltd. Disponível em: $<$ http://dx.doi.org/10.1016/j.applthermaleng.2014.01.011>. .

RANGARAJAN, B.; HAVEY, A.; GRULKE, E. A.; CULNAN, P. D. Kinetic Parameters of a Two-Phase Model for in situ Epoxidation of Soybean Oil. Journal of the American Oil Chemists' Society, v. 72, n. 10, p. 1161-1169, 1995.

SAMARTH, N. B.; MAHANWAR, P. A. Modified Vegetable Oil Based Additives as a Future Polymeric Material - Review. Open Journal of Organic Polymer Materials, v. 5, n. January, p. 1-22, 2015.

SIEBERT, C. A.; DOANE, D. V.; BREEN, D. H. The Hardenability of steels: concepts, metallurgical influences, and industrial applications. Metals Park: American Society for Metals, 1977.

SILVA, A. L. V. DA C. E; MEI, P. R. Aços e Ligas Especiais. $2^{a}$ ed. São Paulo: Edgard Blucher, 2006.

SMITH, S. A.; KING, R. E.; MIN, D. B. Food Chemistry Oxidative and thermal stabilities of genetically modified high oleic sunflower oil. Food Chemistry, v. 102, n. 2007, p. 1208-1213, 2007.

TOTTEN, G. E.; BATES, C. E.; CLINTON, N. A. Handbook of quenchants and quenching technology. Ohio: ASM International, 1993.

TOTTEN, G. E.; NARAZAKI, M.; BLACKWOOD, R. R. Failures Related to Heat Treating Operations. Manufacturing Aspects of Failure and Prevention. p.1-32, 2002. 